UNIVERSIDADE DE SÃO PAULO

FACULDADE DE ECONOMIA, ADMINISTRAÇÃO E CONTABILIDADE DEPARTAMENTO DE ADMINISTRAÇÃO PROGRAMA DE PÓS-GRADUAÇÃO EM ADMINISTRAÇÃo

O COMPORTAMENTO DO EMPREENDEDOR E SUAS INFLUÊNCIAS NO PROCESSO DE CRIAÇÃO E NO DESEMPENHO DA EMPRESA

Eduardo Pinto Vilas Boas

Orientador: Prof. Dr. Silvio Aparecido dos Santos

SÃo PAULO 
Prof. Dr. Marco Antonio Zago Reitor da Universidade de São Paulo

Prof. Dr. Adalberto Américo Fischmann Diretor da Faculdade de Economia, Administração e Contabilidade Prof. Dr. Roberto Sbragia Chefe do Departamento de Administração

Prof. Dr. Moacir de Miranda Oliveira Júnior Coordenador do Programa de Pós-Graduação em Administração 


\section{O COMPORTAMENTO DO EMPREENDEDOR E SUAS INFLUENCIAS NO PROCESSO DE CRIAÇÃO E NO DESEMPENHO DA EMPRESA}

Tese apresentada ao Departamento de Administração da Faculdade de Economia, Administração e Contabilidade da Universidade de São Paulo, como um dos requisitos para obtenção do título de Doutor em Ciências.

Orientador: Prof. Dr. Silvio Aparecido dos Santos

Versão Corrigida

(versão original disponível na Faculdade de Economia, Administração e Contabilidade)

\section{SÃO PAULO}




\section{FICHA CATALOGRÁFICA}

Elaborada pela Seção de Processamento Técnico do SBD/FEA/USP

Vilas Boas, Eduardo Pinto.

O comportamento do empreendedor e suas influências no processo de criação e no desempenho da empresa / Eduardo Pinto Vilas Boas. -- São Paulo, 2015. $149 \mathrm{p}$.

Tese (Doutorado) - Universidade de São Paulo, 2015. Orientador: Silvio Aparecido dos Santos.

1. Empreendedorismo. 2. Administração de empresas. 3. Comportamento. 4. Desempenho organizacional. 5. Perfil empreendedor. I. Universidade de São Paulo. Faculdade de Economia, Administração e Contabilidade. II. Título. 
A meus pais, com amor. 


\section{AGRADECIMENTOS}

Agradeço ao Professor Dr. Silvio Aparecido dos Santos pelos anos de dedicação como orientador deste trabalho. Seus ensinamentos enquanto orientador, professor e ser humano serão levados como lições grandiosas para o futuro.

À minha família, em especial, ao meu pai, Luiz Eduardo, a minha mãe, Maria de Lourdes e a minha irmã, Marina. O carinho e apoio deles foram essenciais para tornar essa longa jornada mais fácil.

À Patrícia Franco, que colaborou com carinho e compreensão em todos os momentos. Além do apoio necessário para a vida toda.

Aos colegas do GPEADE pelas críticas, contribuições e ideias durante todo o processo de amadurecimento desta tese. Em especial ao colega Prof. Dr. Márcio Kuniyoshi que foi muito solicito sempre que requisitado.

Ao Prof. Dr. Leandro Campi Prearo que ofereceu seu tempo e seu conhecimento para auxiliar a elaboração de todo arcabouço estatístico dessa tese.

À Neide que ofereceu todo o apoio logístico para que o trabalho pudesse ser realizado.

À USP e a todos os funcionários e professores da Pós-Graduação e da biblioteca que contribuíram sempre que foram solicitados para que esse trabalho fosse possível.

Aos amigos que fiz durante a Pós-Graduação e puderam contribuir com conhecimento, mas especialmente com carinho nos momentos que foram necessários. São amigos que serão levados para a vida toda.

A todos os amigos que me acompanharam nessa jornada e que enviaram ao menos boas energias e vibrações para torna-la mais fácil.

A Deus por me iluminar e ajudar a definir o melhor caminho. 


\section{RESUMO}

O objetivo desta tese foi verificar se o perfil do empreendedor e seu respectivo comportamento durante o processo empreendedor (processo de criação da empresa) influenciavam o desempenho da empresa criada. Para viabilizar o alcance do seu objetivo, inicialmente verificou-se o tipo de perfil e o respectivo tipo de comportamento predominantes na amostra analisada. O método principal utilizado na pesquisa é descritivo, sendo esta preponderantemente quantitativa. O perfil empreendedor foi medido com o instrumento proposto por McClelland (1987) e o comportamento do empreendedor foi medido por um instrumento criado e proposto pelo autor, visando entender o comportamento explicitado durante a criação da empresa, entre dois extremos, o causal e o effectual. Para identificar o conjunto de características mais presentes no perfil e o comportamento predominante em cada atividade do processo empreendedor foram utilizadas estatísticas descritivas. Na sequência, a análise de clusters foi realizada para identificar a existência de diferentes tipos de comportamento empreendedor. No entanto, para atingir o principal objetivo a técnica utilizada foi a modelagem de equações estruturais, mais especificamente o método de partial least square (PLS-SEM). Os dados foram coletados por meio de um questionário autoadministrado enviado por meio eletrônico para mais de 100.000 pessoas cadastradas em um dos principais sítios brasileiros de auxílio a empreendedores, dos quais 467 retornaram e 457 foram aproveitados após análise de outliers uni e multi variados. Os resultados revelaram que o perfil empreendedor tinha maior ocorrência de características do grupo de planejamento, seguido pelo grupo de realização e depois pelo poder. Também revelaram que o comportamento geral dos empreendedores é mais causal do que effectual, sendo que dezesseis atividades são realizadas com ênfase causal e apenas dez com ênfase effectual. Esse achado diverge da teoria recente do comportamento empreendedor que propõe a prevalência do comportamento effectual. Ainda em relação ao comportamento do empreendedor verificou-se a existência de três tipos distintos de comportamento, um comportamento mais causal (age de forma precavida, com planejamento prévio de suas ações), um comportamento intermediário (alterna a forma de agir entre planejamento prévio e ação não precedida de planejamento) e um comportamento mais effectual (age sem planejamento e posteriormente enfrenta as possíveis consequências). Um achado do estudo em relação aos tipos de comportamento foi constatar que os empreendedores modificam o seu padrão de comportamento ao longo do processo, sendo que os empreendedores que iniciam o processo de maneira mais causal tendem a ser menos causais conforme o seu avanço e os empreendedores que iniciam effectuais, tendem a ser menos effectuais ao longo do processo. Finalmente, respondendo ao objetivo principal da tese, relacionando o perfil, comportamento e desempenho, é possível afirmar que tanto o perfil quanto o comportamento influenciaram o desempenho da empresa criada. O comportamento demonstrou capacidade de exercer maior influência do que o perfil, especialmente o comportamento com ênfase causal. Foi verificado também que o modelo apresentado se adequa melhor aos empreendedores do setor de comércio tradicional do que ao setor de serviços.

Palavras-chave: Empreendedorismo, comportamento empreendedor, perfil empreendedor, desempenho organizacional, causation, effectuation 


\begin{abstract}
The purpose of the thesis is to verify whether the profile of the entrepreneur and his behavior during the entrepreneurial process (the creation of a company) influence the performance of the company created. In order to enable the scope of such purpose, there were initially verified the type of profile and the correspondent type of behavior predominant in the sample analyzed. The main method used on the research is descriptive, being the research predominantly quantitative. The entrepreneurial profile was measured by the instrument proposed by McClelland (1987) and the behavior of the entrepreneur was measured by an instrument created and proposed by the author of this thesis, aiming to understand the behavior shown during the creation of the company, between two extremes, the causal and the effectual. In order to identify the group of characteristics predominant in the profile and the predominant behavior in each activity of the entrepreneurial process, there were used descriptive statistics. Following that, the analysis of clusters was made to identify the existence of different types of entrepreneurial behavior. However, in order to achieve the main purpose, the technique used was the structural equation modeling, more specifically the partial least square (PLS-SEM) method. The data were collected through a self-administrated questionnaire sent electronically to more than 100.000 people registered on one of the Brazilian main websites of support to entrepreneurs, 467 of which have returned and 457 were used after analysis of uni and multivariate outliers. The results revealed that the entrepreneurial profile presented more of the planning group characteristics, followed by the achievement group and, after that, by the power one. They also revealed that the general behavior of the entrepreneurs is more causal than effectual: sixteen activities are carried out with causal emphasis and only ten with effectual emphasis. These finding differs from the recent theory of the entrepreneurial behavior that proposes the prevalence of the effectual behavior. Still regarding the behavior of the entrepreneur, it was verified the existence of three different types of behavior, one that is more causal (acts on a cautious way, with previous planning of actions), one intermediate behavior (varies the behavior between acting with previous planning and without previous planning) and one more effectual behavior (acts without planning and, afterward, faces possible consequences). One finding of the study, regarding the types of behavior, was to note that entrepreneurs change their pattern of behavior along the process: entrepreneurs that begin the process on a more causal way tend to be less causal as they advance and the entrepreneurs that begin effectual tend to be less effectual along the process. Finally, answering to the main purpose of the thesis, relating profile, behavior and performance, it is possible to affirm that both profile and behavior influence the performance of the company created. It was demonstrated that behavior may exercise greater influence than the profile, especially the behavior with causal emphasis. It was also verified that the model presented suits better to entrepreneurs of the traditional commerce sector than to those from services' sector.
\end{abstract}

Key-words: Entrepreneurship, Entrepreneurial behavior, Entrepreneurial profile, business performance, causal, effectual 


\section{SUMÁRIO}

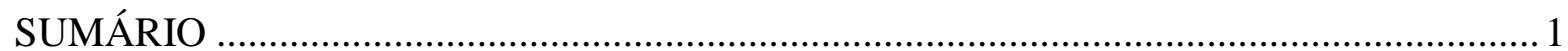

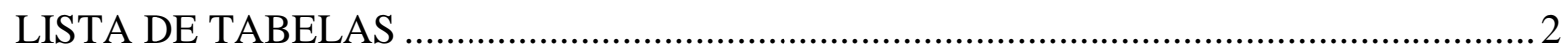

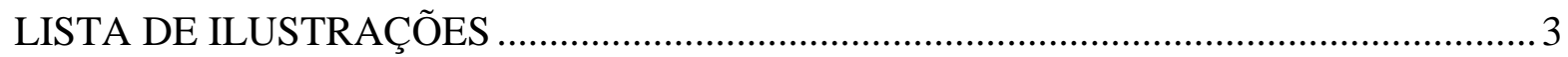

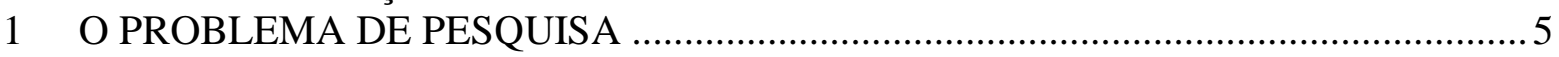

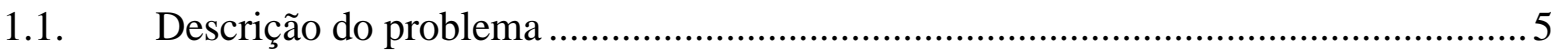

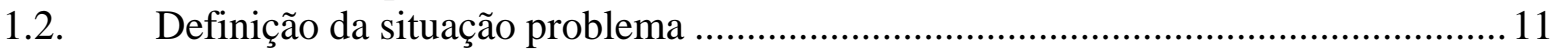

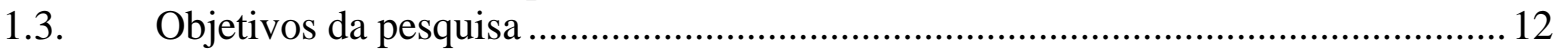

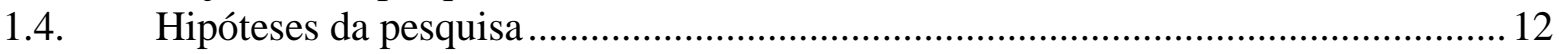

1.5. Definições teóricas e operacionais dos conceitos e variáveis envolvidas ............... 13

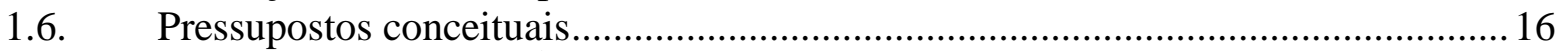

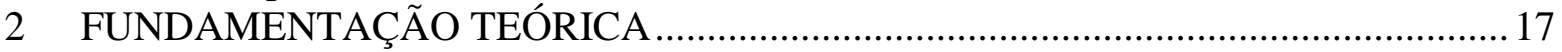

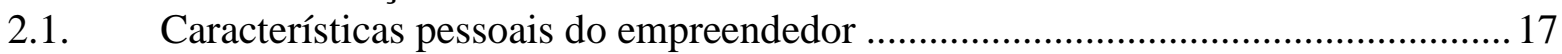

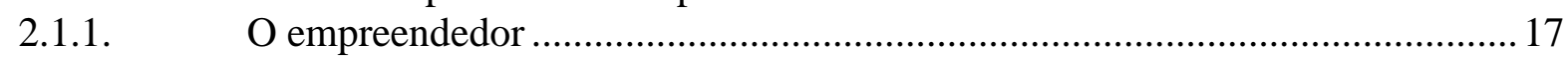

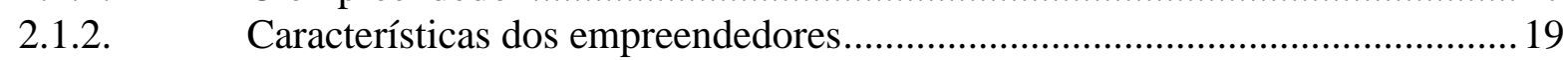

2.1.3. A teoria de David McClelland ..................................................................... 19

2.2. O processo de criação de novas empresas (Processo empreendedor) ...................... 24

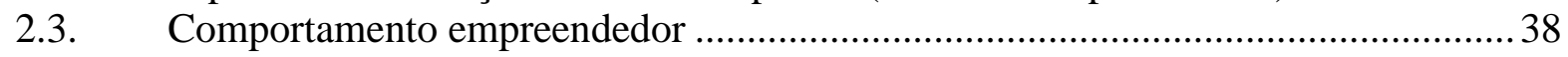

2.3.1. Diferentes abordagens para o comportamento empreendedor ........................ 41

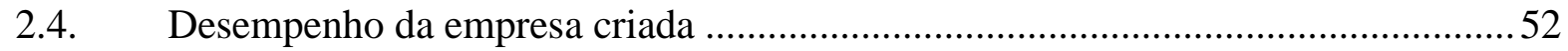

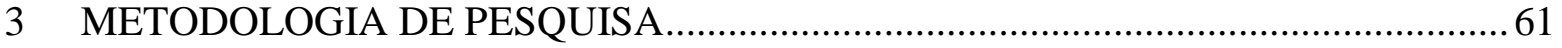

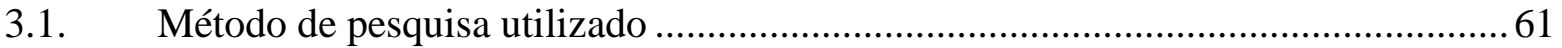

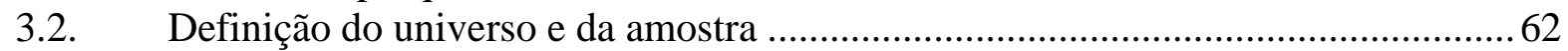

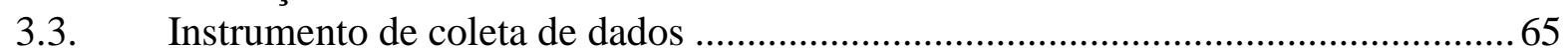

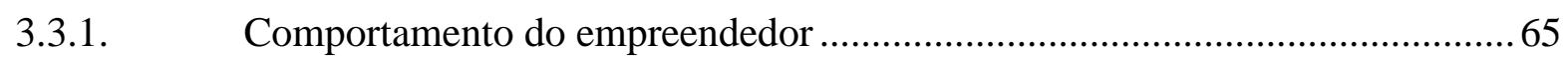

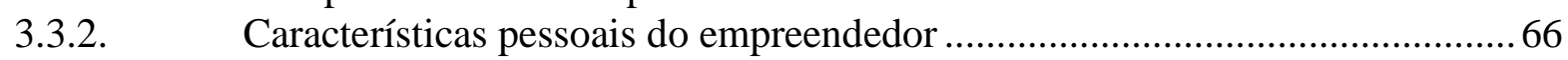

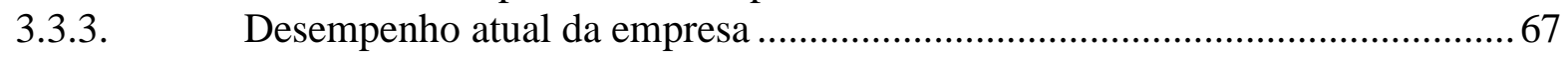

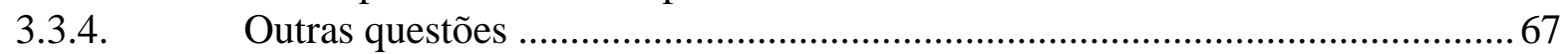

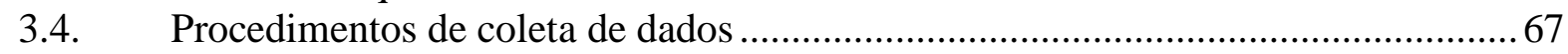

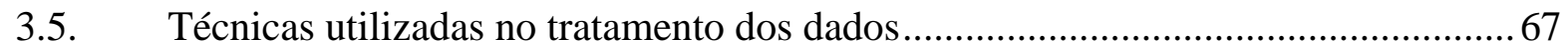

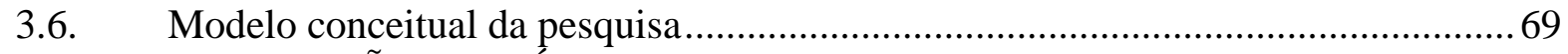

4 APRESENTAÇÃO E ANÁLISE DOS DADOS DA PESQUISA …............................. 71

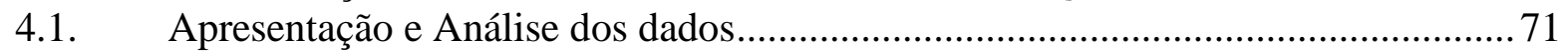

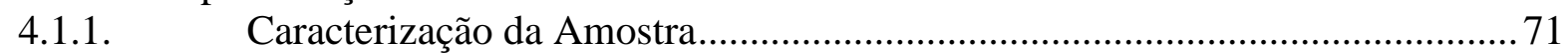

4.1.2. Análise do Perfil Empreendedor ................................................................. 75

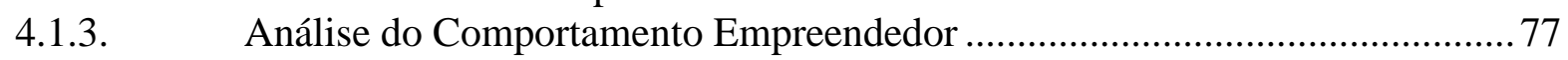

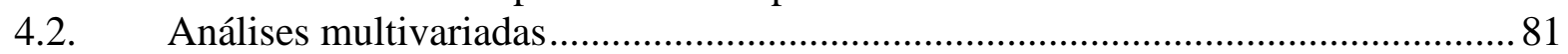

4.2.1. Análise de Clusters .................................................................................. 81

4.2.2. Modelagem de Equações Estruturais - Análise da relação perfil $x$

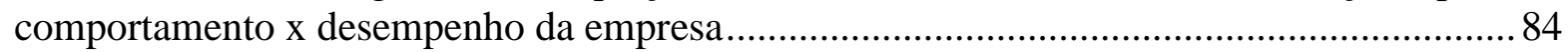

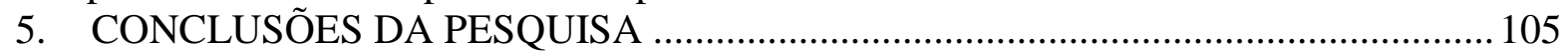

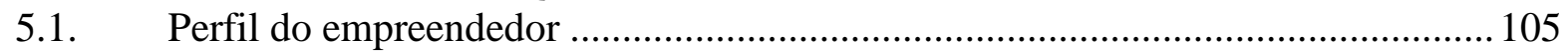

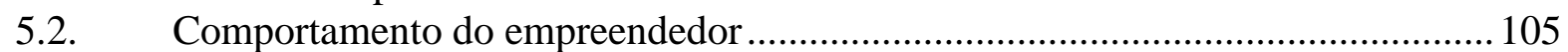

5.3. Relação Perfil x Comportamento x Desempenho …............................................... 107

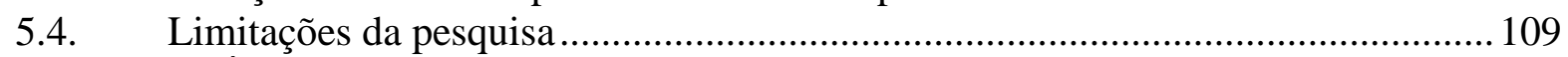

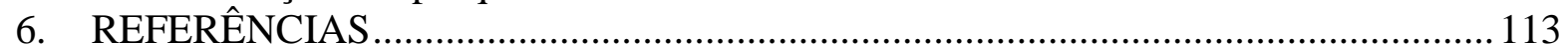

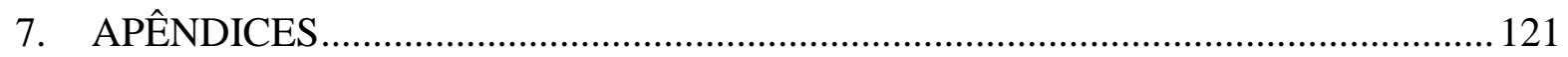




\section{LISTA DE TABELAS}

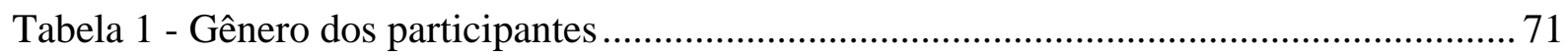

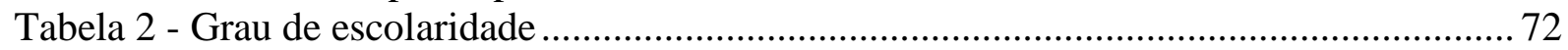

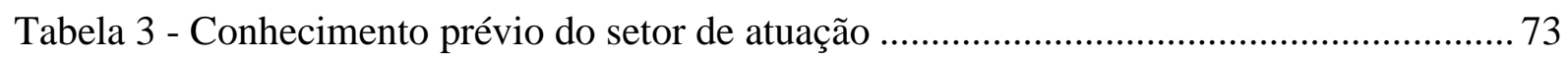

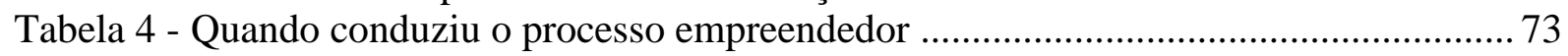

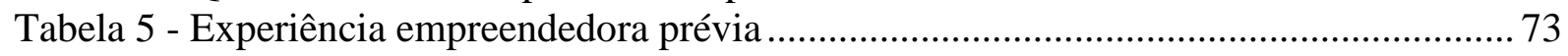

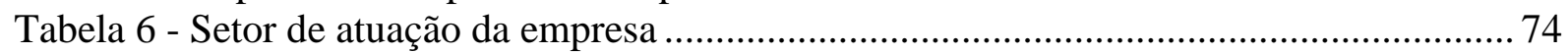

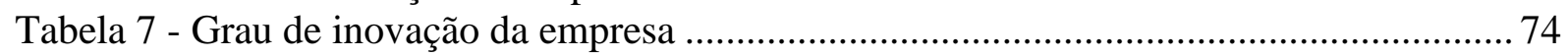

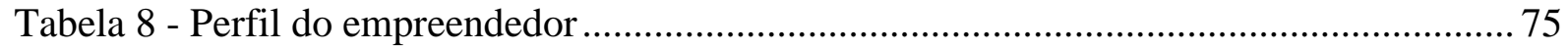

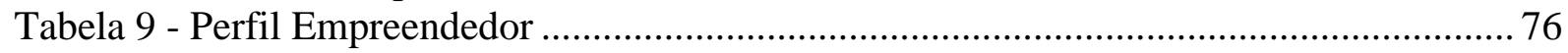

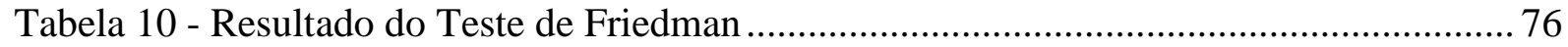

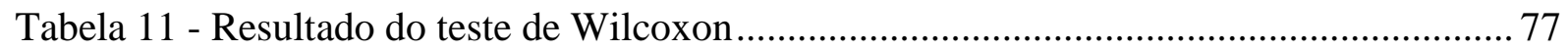

Tabela 12 - Atividades do Processo Empreendedor..................................................................... 77

Tabela 13 - Atividades com mais ênfase em comportamento causal e effectual ..................... 79

Tabela 14 - Grupos de atividades do Processo Empreendedor .............................................. 80

Tabela 15 - Recorte do resultado do cluster utilizando método hierárquico ........................... 81

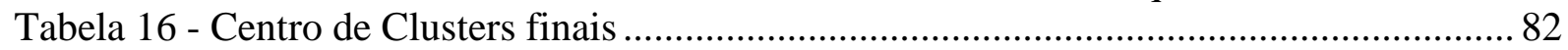

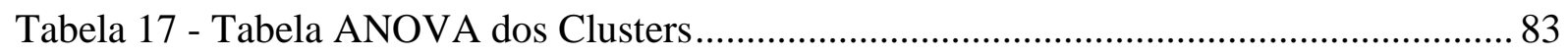

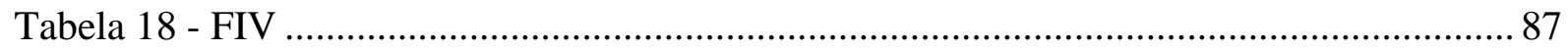

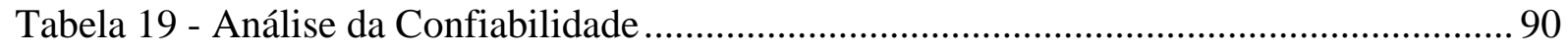

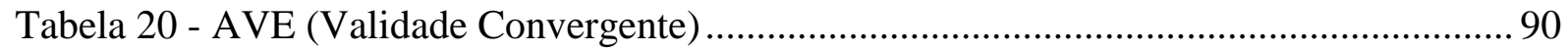

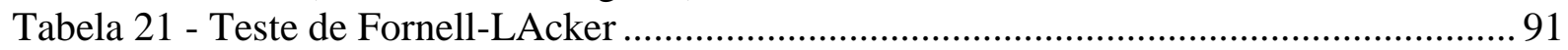

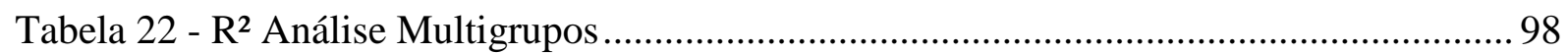

Tabela 23 - Teste de Confiabilidade Multigrupos............................................................. 99

Tabela 24 - Validade Convergente Multigrupos .................................................................. 99

Tabela 25 - Relação entre os Constructos Multigrupos ...................................................... 100

Tabela 26 - Teste $t$ da relação entre os constructos Multigrupos ........................................... 101

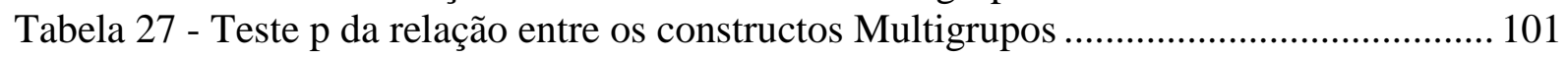

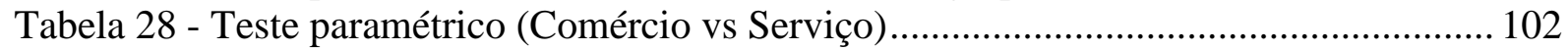

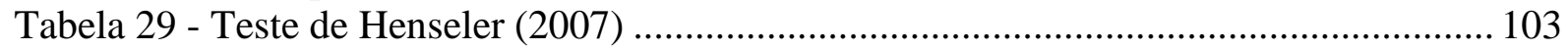




\section{LISTA DE ILUSTRAÇÕES}

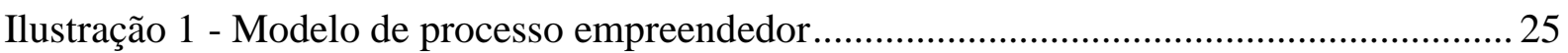

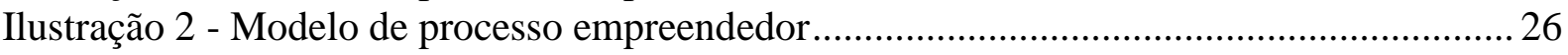

Ilustração 3 - Modelo de processo empreendedor.................................................................... 28

Ilustração 4 - Modelo de processo empreendedor................................................................. 28

Ilustração 5 - Modelo de processo empreendedor...................................................................29

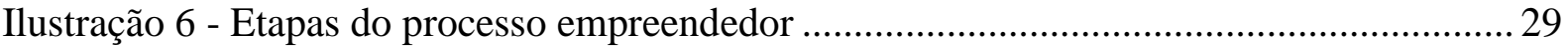

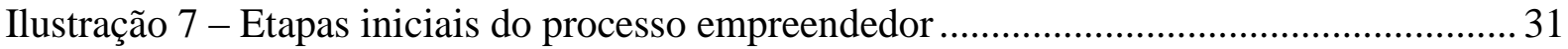

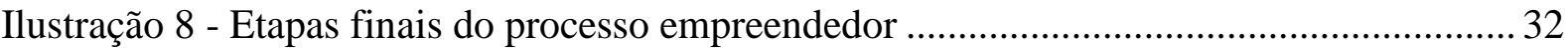

Ilustração 9 - Modelo de processo empreendedor ...................................................................... 33

Ilustração 10 - Modelo de processo empreendedor proposto pelo autor................................... 36

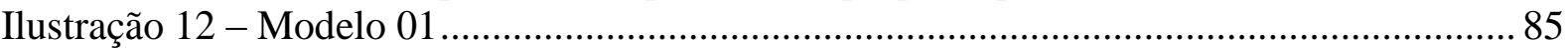

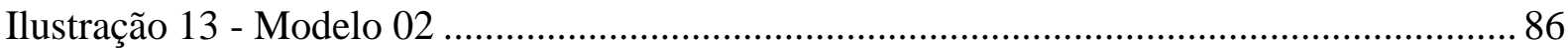

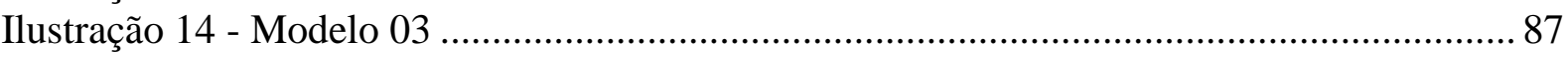

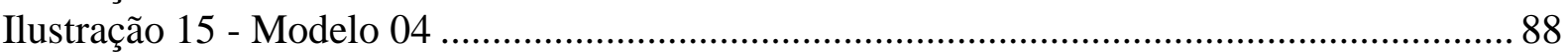

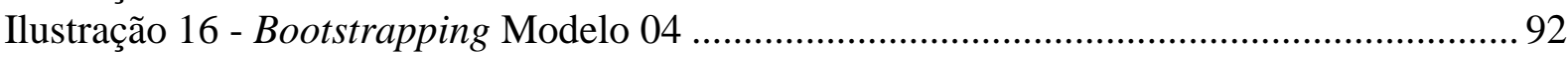

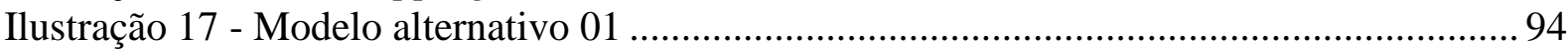

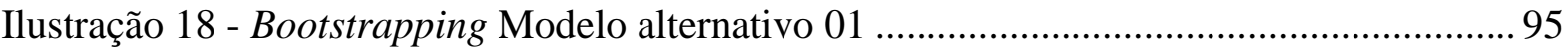

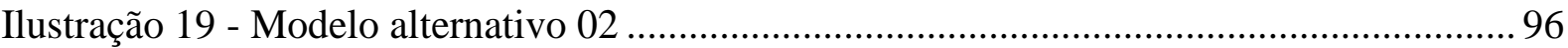

Ilustração 20 - Bootstrapping Modelo alternativo 02 ........................................................... 97 


\section{O PROBLEMA DE PESQUISA}

\subsection{Descrição do problema}

O ambiente de negócios muda constantemente. Novas oportunidades são criadas e descobertas a cada momento, bem como surgem empresas dispostas a explorá-las. Assim, o processo de criação de empresas faz parte da dinâmica da economia capitalista baseada nos princípios da livre concorrência, da propriedade privada e da obtenção de lucros como remuneração dos sócios da empresa.

Ao longo do tempo a economia se renova com o surgimento de novas empresas que ocupam novos espaços no mercado ou que substituem empresas em espaços antes por elas explorados, já que não conseguiram sobreviver. O empreendedorismo é um fenômeno resultante das ações de milhares de empreendedores que a cada ano criam novas empresas.

O nascimento de novas empresas é o resultado esperado de um processo, que recebe o nome de processo empreendedor. Esse processo sofre influência do empreendedor, considerado o agente do processo, e do ambiente, onde o empreendedor está inserido e realiza o processo, que, consequentemente, influencia ambos.

O protagonismo do empreendedor e as influências do ambiente sobre o processo são propostos por autores tais como Santos (1983), Gartner (1985), Moore (1986), Bruyat e Julien (2000) e Shane (2003). Santos (1983) entendia que o processo de criação da empresa é fruto da ação de empreendedores e que sofre influências das forças ambientais propulsoras ou restritivas. Além do processo, do indivíduo e do empreendedor, Gartner (1985) propunha uma quarta variável, a organização. Moore (1986) identificou a influência de fatores pessoais, sociais, organizacionais e ambientais em diferentes fases do processo empreendedor. Bruyat e Julien (2000) propuseram que o empreendedor é o condutor do processo e que, uma vez que este é iniciado, existe uma troca constante entre a nova empresa criada, o empreendedor e o ambiente, que vai mudando ao longo do tempo. Shane (2003) também incluiu em seu modelo os atributos pessoais do empreendedor e os fatores do ambiente como influenciadores do processo empreendedor em diferentes momentos. Mesmo que cada um dos modelos conte 
com peculiaridades, é possível afirmar que são semelhantes e que todos identificam a presença das variáveis processo, empreendedor e ambiente.

Segundo Hisrich et al (2005) o processo empreendedor identifica a ação do empreendedor na criação de uma organização. Como este processo é longo, indo desde a ideia até a consolidação da empresa, autores como Santos (1983), Gartner (1985), Moore (1986), Bhave (1994), Shane (2003) e Hisrich et al (2005) o dividiram em etapas. Não existe consenso entre os autores a respeito de quantas são e quais são essas etapas, variando de quatro a seis nos principais estudos. Dessa forma, embora não seja o objetivo principal desta tese, espera-se oferecer contribuições para a definição do que pode ser caracterizado efetivamente como um processo empreendedor, tornando-se relevante para um ponto importante da teoria do empreendedorismo.

Optou-se nesta tese por dividir o processo em quatro sub-processos. Esses sub-processos, por sua vez, são formados por um conjunto de atividades e podem ou não ocorrer de forma linear. Algumas vezes as atividades de um sub-processo subsequente podem ser realizadas antes de o sub-processo anterior ter sido finalizado.

O primeiro sub-processo abrange todas as ações realizadas pelo empreendedor desde o momento em que ele tem uma ideia, passa pela seleção da oportunidade de negócio mais atrativa e termina com a definição do conceito de negócio que pretende desenvolver para explorá-la. Algumas atividades são comuns nessa etapa, tais como a busca de informações de mercado e de concorrentes, a definição do segmento de clientes que deverá ser atendido, a busca por conhecimentos que irão embasar o novo negócio e também a elaboração de um plano de negócios.

O segundo sub-processo tem início no momento em que o empreendedor se compromete a alocar recursos para a formação da nova empresa, sejam eles próprios ou de terceiros. Entende-se que é nessa etapa que o empreendedor decide que pretende mesmo explorar um novo negócio. Algumas das atividades desse sub-processo são: aumentar a dedicação de tempo ao novo empreendimento, iniciar o desenvolvimento do produto ou serviço que será comercializado, fazer um planejamento financeiro, quantificar os investimentos que serão necessários e buscar reunir recursos próprios ou de terceiros. É muito comum que sócios sejam convidados a participar da nova empresa. 
O terceiro sub-processo consiste na criação da empresa e todos os procedimentos envolvidos para formalizá-la e torná-la operacional. Até esse momento, embora já possa existir informalmente a comercialização de produtos ou serviços, a empresa ainda não foi criada formalmente. Para concluir este sub-processo o empreendedor realiza algumas atividades como registrar patentes e ou direitos comerciais, adquirir máquinas e equipamentos, finalizar o desenvolvimento do produto ou serviço, definir um local para a empresa se instalar, definir a denominação jurídica e a marca da empresa e cumprir todos os procedimentos legais necessários para registrar a empresa e poder emitir nota-fiscal.

O quarto e último sub-processo consiste no gerenciamento da empresa nos primeiros anos de existência para mantê-la no mercado. Nessa etapa as atividades que o empreendedor deve seguir consistem na realização da primeira venda, da primeira ação de divulgação, da contratação do primeiro empregado e do primeiro gestor, inclusive a execução das atividades administrativas de controles financeiros e da negociação com fornecedores e outros parceiros complementadores do negócio.

Os empreendedores são os indivíduos que realizam as atividades do processo empreendedor, portanto são considerados os agentes desse processo. Como as atividades são resultantes de ações praticadas no dia a dia do processo de criação da empresa, estas podem ser consideradas como resultantes da explicitação do comportamento humano do empreendedor. Bird et. al. (2012) definem o comportamento empreendedor como as atividades ou tarefas realizadas por indivíduos, que são necessárias para começar e fazer crescer uma nova organização. É uma unidade de ação orientada por um objetivo e que pode ser observada (BIRD et. al. 2012).

Nesta pesquisa o comportamento humano a ser observado é aquele que pode ser observado no empreendedor durante todo o processo empreendedor (desde a ideia inicial, passando pela decisão de comprometer recursos e pela criação da empresa e os primeiros anos de sua existência), portanto caracteriza-se como um comportamento do empreendedor, enquanto gestor de recursos, líder de equipe e negociador de condições e facilidades para viabilizar o empreendimento.

Sob a ótica das teorias de comportamento, o comportamento empreendedor foi estudado por Bird (1989), Dew et al (2008) e Mueller et al (2012). Bird et al (2012, p. 889) entendem que 
o foco atual dos estudos sobre comportamento empreendedor está em entender a "ação humana na criação, sobrevivência e primeiros estágios de crescimento de uma nova empresa, ou seja, os comportamentos durante a exploração de uma oportunidade de negócio.”.

O comportamento dos empreendedores durante a realização das atividades do processo de criação da empresa difere de pessoa para pessoa, algumas só agem depois de um esforço de planejamento, visando com isto alcançar os melhores resultados, enquanto outras optam por realizar ações antes de qualquer planejamento. Segundo Dew et al (2008), o comportamento humano mais usual na condução de uma organização tende a evitar a incerteza e a gerenciar expectativas de maneira racional, procurando optar sempre pela alternativa que maximiza resultados. Entretanto, ao estudar os empreendedores, estes mesmos autores identificaram que estes preferem optar por soluções satisfatórias e não necessariamente que maximizem os resultados, isto porque, as incertezas podem, em algumas situações, lhes trazer benefícios.

Esse tipo de comportamento humano já havia sido descrito pelo economista Hebert Simon em estudos onde definiu a racionalidade limitada. De acordo com Simon (1959) apud Sbicca e Fernandes (2005) os conceitos de racionalidade limitada envolvem: a busca de soluções satisfatórias ao invés de otimizadoras, e a substituição de objetivos abstratos por sub objetivos tangíveis que possam ser mensurados e cujo desempenho pode ser observado.

A proposição de que os empreendedores seguem um comportamento planejado e têm o objetivo de maximizar o retorno, segundo Endres e Woods (2006), foi feita pelos autores que estudaram o empreendedorismo nas escolas neoclássica e austríaca. Os neoclássicos basearam seus estudos em estudos teóricos anteriores, sem realizar exames ou testes empíricos para analisar o empreendedor e acreditavam que eles sempre analisavam o risco de forma sistemática, ou seja, sempre avaliavam as oportunidades e as possíveis consequências de suas ações, e que procuravam otimizar o retorno em relação ao risco que corriam. A escola austríaca também acreditava que o empreendedor pretendia maximizar os retornos, mas, ao realizar mais observações empíricas do comportamento do que os neoclássicos, identificou que em alguns casos não é possível prever com exatidão o risco, visto que as probabilidades de sucesso ou insucesso só serão conhecidas após o início do processo de criação da empresa.

Segundo Endres e Woods (2006), uma nova escola que estuda o comportamento empreendedor, para entender como ele ocorre durante o processo, usando mais evidências 
empíricas para analisar o comportamento do empreendedor está surgindo. Os autores dessa escola acreditam que, como o ambiente é muito instável, os empreendedores não conseguem sempre conhecer e analisar as opções e, consequentemente, não conseguem escolher pelo conjunto de atividades que a priori garantam a maximização de retornos da empresa criada. Dessa forma as oportunidades a serem exploradas não estão todas disponíveis para serem descobertas pelos empreendedores, como acreditavam os autores das escolas anteriores, mas são criadas pelo empreendedor em um processo contínuo que envolve suas aspirações pessoais, a oportunidade e o ambiente. A oportunidade criada é única, moldada pelo empreendedor ao longo do tempo.

Independentemente do confronto teórico, o fato é que existem empreendedores que agem orientados por um objetivo de longo prazo, que é definido previamente com base na previsão de qual será a realidade futura mais provável e qual a posição que sua empresa pretende ocupar neste mercado projetado. Esses empreendedores procuram planejar suas atividades e avaliar cautelosamente suas prováveis consequências. Além disso, evitam desviar-se do caminho trilhado. A ferramenta mais utilizada pelos empreendedores que se comportam dessa forma é a formulação de um plano de negócios. Esse comportamento dos empreendedores é baseado na precaução e na tentativa de previsão do futuro, por meio do planejamento antecipado, que deve orientar o empreendedor e sua forma de agir na condução do processo empreendedor.

Conforme Sarasvathy (1998), estes empreendedores, por meio de suas ações explícitas, podem ser classificados como aqueles que explicitam um comportamento empreendedor do tipo causation, ou seja, aqueles que atuam de forma precavida, antecipando por meio de busca de informações e planejamento todas as possíveis variáveis e situações que poderão influenciar de forma positiva ou negativa a criação e o desenvolvimento de sua empresa. $\mathrm{O}$ detalhamento desta abordagem teórica e de seus respectivos defensores será feito mais à frente, na fundamentação teórica.

Outros empreendedores explicitam um comportamento diferente na condução do processo empreendedor. Costumam orientar-se de acordo com suas intuições, priorizando e executando as ações contingenciais, requeridas pelo dia a dia da empresa, contando somente com os meios e as informações que possuem em mãos. Esses empreendedores acreditam que é muito difícil, ou até mesmo impossível, prever o futuro e, portanto, preocupam-se em fazer as 
atividades com foco no presente. Entende-se que esses empreendedores focam suas energias no cotidiano e acreditam que, fazendo isso, irão garantir um futuro para a sua empresa. Eles mostram sua competência em lidar com situações emergentes da forma como podem e com os recursos que possuem à mão, já que só podem contar com o que têm e com o que podem fazer.

Para Sarasvathy (1998) estes empreendedores que preferem partir do que têm em mãos para criar uma empresa sem preocupar-se com as precauções do que necessitariam em recursos e informações, podem ser classificados pela natureza de seu comportamento com os do tipo effectuation, ou seja, obtêm resultados positivos ou não e, em seguida, reagem a isto de forma intuitiva e deliberada num processo de ajustamento do seu agir que emerge do que deu certo e do que não deu.

O reconhecimento da existência de comportamentos empreendedores distintos, ou seja, planejar e fazer, ou fazer sem planejar e depois remediar, representa as duas correntes teóricas do estudo do comportamento do empreendedor na condução do processo de criação de uma empresa.

Uma vez que existem comportamentos diferentes do empreendedor durante o processo de criação de empresas, tendo por base a maneira como executam as atividades, é importante entender melhor a respeito do empreendedor e dos fatores que podem guiar ou induzir seu comportamento. Uma das possibilidades a serem consideradas para conhecer melhor o empreendedor é o estudo de suas características, ou seja, como ele estará propenso a agir diante de situações típicas do processo empreendedor que ele conduz.

Os estudos a respeito das características pessoais dos empreendedores tiveram início na década de 60, com as propostas do psicólogo David McClelland (1961), que pesquisou as motivações que levavam os empreendedores a agir. Suas pesquisas encontraram três motivações principais: a necessidade de realização, a necessidade de afiliação e a necessidade de poder. Posteriormente, McClelland (1987) realizou um estudo com empreendedores de quatro países, procurando identificar quais eram as características que estavam mais presentes nesses indivíduos. Esse estudo identificou que dez características estavam mais presentes nos empreendedores de empresas que obtinham êxito. São elas: busca de oportunidade e iniciativa, comprometimento, persistência, busca de qualidade e eficiência, tomar riscos 
calculados, estabelecimento de metas, planejamento e monitoramento sistemático, busca de informações, persuasão e rede de contatos e independência e autoconfiança.

O estudo de McClelland desenvolveu um instrumento, que é utilizado no programa Empretec (Programa de desenvolvimento do empreendedorismo), das Nações Unidas. Ao ser utilizado nesse programa, as características empreendedoras receberam o nome de Características Pessoais do Empreendedor e foram divididas em três grupos: Realização, Planejamento, e Poder.

Acredita-se que as características do empreendedor e o comportamento explicitado durante a condução do processo empreendedor influenciem o desempenho da empresa criada. Essa relação ainda não foi comprovada por estudos empíricos e será a principal contribuição esperada do presente estudo.

\subsection{Definição da situação problema}

Tendo como base que o comportamento é o conjunto de ações realizadas durante o processo de criação e condução na fase inicial da nova empresa, e que cada uma dessas ações pode ser realizada de maneira mais effectual ou de maneira mais causal, acredita-se que não exista uma uniformidade nos padrões de comportamento explícito entre os empreendedores na condução do processo de criação e desenvolvimento de suas respectivas empresas.

Sendo o comportamento do empreendedor crucial na condução do processo de criação de empresas, suspeita-se de que ele possa influenciar o desempenho do empreendimento, no caso desta pesquisa, da empresa criada. Dessa maneira, espera-se que este estudo permita definir se o comportamento do empreendedor durante o processo de criação da empresa influencia o desempenho da empresa criada, após o seu estabelecimento e consolidação.

O desempenho da empresa foi constatado por meio da opinião declarada de cada empreendedor mensurado pelo comportamento de alguns indicadores de desempenho nos últimos três anos da empresa. O objetivo do estudo não foi comparar o desempenho de uma empresa em relação à outra, mas, sim, identificar se o comportamento durante a condução do 
processo empreendedor influenciou o nível de desempenho da empresa após estar consolidada.

\subsection{Objetivos da pesquisa}

1) Verificar quais características empreendedoras são identificadas com mais frequência nos empreendedores.

2) Verificar se os empreendedores explicitam mais o comportamento do tipo effectual ou do tipo causal durante a condução do processo empreendedor.

3) Medir a influência do comportamento tipo effectual ou tipo causal durante o processo empreendedor no desempenho da empresa criada.

4) Propor um modelo de classificação do perfil e do comportamento do empreendedor, durante a condução do processo empreendedor, e do desempenho da empresa.

\subsection{Hipóteses da pesquisa}

Tendo em vista a suspeita deste pesquisador de que o perfil do empreendedor e o seu comportamento durante o processo de criação da empresa influenciam a situação posterior da empresa criada, definem-se as seguintes hipóteses nulas de pesquisa que serão sujeitas a testes:

$\mathrm{H}_{0} 1$ : Não existem diferenças significativas no desempenho de empresas criadas e conduzidas por empreendedores que explicitam comportamento tipo "causal" em comparação com empreendedores que explicitam comportamento tipo "effectual".

$\mathrm{H}_{0}$ 2: Não existem diferenças significativas no desempenho de empresas criadas e conduzidas por empreendedores que explicitam perfil com predominância de características voltadas ao planejamento em comparação com empreendedores com predominância de características voltadas à realização e/ou ao poder. 


\subsection{Definições teóricas e operacionais dos conceitos e variáveis envolvidas}

Teoricamente, empreendedor é definido por Schumpeter (1982) como o indivíduo responsável por identificar oportunidades e propor novos produtos, meios de produção e mercados que, ao serem explorados, deverão alterar a ordem econômica vigente e renovar a economia.

Operacionalmente, o empreendedor foi identificado como o indivíduo que está ou esteve em algum momento de sua vida envolvido diretamente na condução do processo de criação de uma empresa própria, desde a concepção da ideia até os três primeiros anos de existência.

Teoricamente, as características pessoais do empreendedor são definidas pela UNCTAD (2013) como um conjunto de dez características identificadas por McClelland (1987) como as mais presentes em empreendedores de empresas que obtiveram êxito em diferentes países.

Operacionalmente, as características pessoais do empreendedor foram identificadas por meio da aplicação de um instrumento de pesquisa desenvolvido por McClelland para a UNCTAD, que já foi aplicado a diversos empreendedores desde a década de 1980. O instrumento identifica o nível de presença de dez características (pró-atividade; persistência; comprometimento; busca de qualidade e eficiência; acolhe riscos calculados; orientado por objetivos; procura informações; planejador e controlador; persuasivo e sustentador de redes de contatos; e mostra independência e auto-confiança), que são agrupadas em três grupos (realização, planejamento e poder).

Teoricamente, o processo empreendedor é definido por Hisrich et al (2005) como o conjunto de atividades e tarefas que os empreendedores fazem e como fazem para criar uma empresa. O processo empreendedor é composto por quatro sub-processos (ideia e concepção do modelo de negócios; decisão de comprometer recursos; criação e legalização da empresa; e gerenciamento da empresa no período inicial), que, por sua vez, abrangem as atividades e tarefas realizadas pelos empreendedores. 
Operacionalmente, o processo empreendedor foi identificado pelas ações explicitas dos empreendedores durante a condução do processo empreendedor que resulta na criação e gerenciamento do período inicial de operação da empresa no mercado. Em suma todas as ações que o empreendedor faz para realizar as atividades do processo empreendedor que podem ser observadas.

Teoricamente, effectuation é definido por Sarasvathy (1998) como um tipo de comportamento, representado por um conjunto de ações que se inicia por uma causa ou conjunto de causas e iterativamente evolui por meio de uma seleção de possibilidades dentre um conjunto grande de possíveis efeitos, usando tanto métodos de tentativa e erro quanto mecanismos de feedback de todos os tipos. Ele é identificado pela prevalência de ações do empreendedor a partir dos recursos que tem em mãos para conduzir cada uma das atividades que constam no processo empreendedor, sem preocupar-se com planejamento prévio, ou seja, agir e, em seguida, reagir em função dos resultados, de forma intuitiva e deliberada num processo de ajustamento que emerge do que deu certo e do que não deu.

Operacionalmente, o comportamento do tipo effectual foi identificado por meio da resposta dos entrevistados sobre como foi sua atuação diante de frases afirmativas que identificam as diversas ações que um empreendedor realiza ao longo do processo empreendedor. Os respondentes deveriam lembrar-se de como essas ações foram realizadas no momento em que criavam suas empresas. Cada uma dessas ações poderia ser realizada com base no planejamento prévio e consequente benefício futuro ou com foco nos benefícios imediatos. Quanto menor o planejamento envolvido nas realizações das ações, mais effectual é o comportamento do empreendedor.

Teoricamente, causation é definida por Sarasvathy (1998) como o tipo de comportamento oposto de effectuation. Ou seja, é uma forma de se comportar que assume um efeito como dado e seleciona dentre as possíveis causas como atingir o efeito desejado. É um tipo de comportamento onde se planeja antes da realização de qualquer ação.

Operacionalmente, o comportamento do tipo causal foi identificado por meio das questões afirmativas que identificam as ações que devem ser realizadas durante o processo empreendedor. O comportamento causal foi identificado quando as ações tinham foco na 
busca de informações e no planejamento prévio das possíveis consequências que influenciarão a empresa durante o processo e também no seu futuro.

Teoricamente, o comportamento empreendedor pode ser definido segundo Bird et al (2012, p. 889) como a "ação humana na criação, sobrevivência e primeiros estágios de crescimento de uma nova empresa, ou seja, os comportamentos durante a exploração de uma oportunidade". Mueller et al (2012) têm entendimento semelhante. Para eles, o foco desses estudos é descobrir o que os empreendedores realmente fazem.

Operacionalmente, o comportamento empreendedor foi identificado pelo tipo de comportamento que o empreendedor declarou que utilizou ao realizar as ações explícitas durante a condução do processo empreendedor. Ao todo são 26 ações divididas em 4 subprocessos do processo empreendedor, a saber: Ter a ideia e definir o conceito do negócio; decisão de comprometer recursos; decisão de criação da empresa formal; gerenciamento dos primeiros anos da empresa criada.

Teoricamente, o desempenho da empresa é definido por Murphy et al (1996) que identificaram que a maioria das métricas utilizadas para medir o desempenho da empresa provem das teorias das organizações e/ou da estratégia, que pode ser dividida em três correntes teóricas. A primeira, que analisa uma empresa essencialmente pelo seu desempenho financeiro; a segunda, que também leva em conta a qualidade do produto e a participação de mercado (que de alguma forma também acabam por afetar o desempenho da empresa no longo prazo); e a terceira, que considera múltiplas variáveis.

Operacionalmente, o desempenho da empresa foi constatado por meio da opinião do próprio empreendedor sobre o desempenho atual do seu negócio. Para isso foram apresentados para ele alguns parâmetros para balizar a sua resposta (algumas variáveis típicas de resultados finais esperados de um processo empreendedor), no caso, o resultado final de um processo empreendedor são algumas variáveis que medem a situação atual de sua empresa. As variáveis apresentadas a ele para que ele auto-avaliasse a evolução da sua empresa nos últimos três anos foram as seguintes: alterações na quantidade de vendas, base de clientes, receita, lucro líquido, e quantidade de empregados. Essa forma de medir desempenho baseada nas respostas que expressam o julgamento do próprio empreendedor, sem a devida comparação com empresas que competem no mesmo segmento, é limitada, mas tem sido um 
recurso utilizado por pesquisadores tais como Brush e Vanderwerf (1992) e Chandler e Hanks (1993), em que o objetivo é verificar o efeito de uma variável dependente sobre a variável independente desempenho.

\subsection{Pressupostos conceituais}

Para efeito deste estudo foram assumidos os seguintes pressupostos:

1) Assume-se como pressuposto que é possível identificar e medir o nível de presença de determinadas características nos empreendedores utilizando o instrumento de pesquisa desenvolvido por McClelland (1987). Essas características foram identificadas por McClelland (1987) ao analisar donos de empresas que obtiveram êxito em suas atividades em diversos países, e a UNCTAD (2013) vem utilizando este instrumento desde o final da década de 1980 em um projeto conhecido como Empretec. No Brasil esse projeto é realizado em parceria com o SEBRAE e já treinou mais de 160.000 empreendedores (UNCTAD, 2011).

2) Assume-se como pressuposto que o processo para a criação de uma nova empresa, também conhecido por processo empreendedor, compreende, segundo Bygrave (2004), o conjunto de funções, atividades e ações que um empreendedor realiza desde a percepção de uma oportunidade até a criação de uma organização. Conduzir a empresa criada na sua fase inicial também exige comportamento de empreendedor e por isso os primeiros anos de gestão da empresa também serão considerados parte do processo empreendedor nesta tese.

3) Assume-se que a partir de ações explícitas e declaradas como realizadas pelo empreendedor, durante a condução do processo de criação de uma nova empresa, seja possível identificar o comportamento empreendedor de natureza effectual ou de natureza causal. Essa abordagem já foi utilizada e corroborada por Sarasvathy (1998). 


\section{FUNDAMENTAÇÃO TEÓRICA}

A fundamentação teórica dessa pesquisa está dividida em quatro grandes áreas. A primeira refere-se ao empreendedor, principalmente ao seu perfil e às suas características, especificamente às observadas por McClelland (1987). A segunda grande área refere-se ao processo empreendedor, a terceira área ao comportamento do empreendedor, com foco especial para o comportamento effectual e causal identificados por Sarasvathy (1998) e a quarta e última tem foco na revisão da literatura sobre o desempenho da empresa.

\subsection{Características pessoais do empreendedor}

\subsubsection{O empreendedor}

Ao longo dos anos, várias pesquisas foram conduzidas para estudar a figura e o papel do empreendedor, mas não existe ainda um consenso sobre essas definições, como identificado por Campos (2007, p.10) “[...] observa-se uma preocupação mais científica sobre o tema empreendedorismo, mas percebe-se que não há um consenso sobre a figura do empreendedor entre os autores.”. Fillion (1997) ao analisar trabalhos anteriores identificou que cada pesquisador tende a usar premissas de sua área para definir o empreendedor, mas que é possível dividir os trabalhos em duas linhas principais, a dos economistas e a dos comportamentalistas. Para os economistas, os empreendedores estão sempre ligados à inovação e são a força direcionadora do desenvolvimento. Para os comportamentalistas (psicólogos, psicanalistas, sociólogos, dentre outros), cujos estudos ganharam relevância após os trabalhos de David McClelland, os empreendedores são ligados à características como criatividade e intuição.

$\mathrm{Na}$ linha dos economistas, um dos pioneiros nos estudos de empreendedorismo e do empreendedor foi o economista austríaco Schumpeter (1982), cujos principais trabalhos foram publicados entre as décadas de 1910 e 1940. Ele identificou a existência de um fenômeno que pode influenciar o desenvolvimento econômico por meio da renovação da economia e que ele nomeou como destruição criativa. Nesse conceito, os empreendedores são considerados os responsáveis por identificar oportunidades e propor novos produtos, meios de produção e mercados que, ao serem explorados, deverão alterar a ordem econômica vigente, 
pois podem substituir empresas decadentes e então renovar a economia. Schumpeter (1982) entendia que o empreendedor, para liderar essa atividade, precisa ter a habilidade de identificar oportunidades para obter lucros e assumir os riscos inerentes à essa ação, visão esta que também foi assumida posteriormente por Fillion (1997).

$\mathrm{Na}$ linha de estudo dos comportamentalistas, Fillion (1999) concluiu que o pioneiro e principal representante foi o psicólogo de Harvard David McClelland, que, em seu estudo inicial, realizado em 1961, buscou evidências históricas para explicar a existência de grandes civilizações. Ele identificou que o principal elemento comum a essas civilizações é a presença de heróis na literatura, o que levava as gerações seguintes a adotá-los como modelo e imitar seu comportamento.

Ao analisar os estudos de McClelland e seus sucessores, Fillion (1999, p. 19) concluiu que "O empreendedor é uma pessoa criativa, marcada pela capacidade de estabelecer e atingir objetivos e que mantém alto nível de consciência do ambiente em que vive, usando-a para detectar oportunidades de negócios". A capacidade de definir e alcançar objetivos pode caracterizar o empreendedor como um visionário, que enxerga além do seu tempo e busca os meios para alcançar o futuro desejado.

Assim como Fillion (1997), outros autores afirmaram que ainda existem lacunas nos estudos dos comportamentalistas sobre o empreendedor. Baum et al (2007, p.1) afirmaram que “[...] apesar da crença de que as características pessoais do empreendedor são importantes para o sucesso da nova empresa, a psicologia dos empreendedores ainda não foi totalmente estudada".

A literatura científica sobre a classificação do empreendedor em diferentes papéis na sociedade é abrangente, e neste estudo será considerado empreendedor todo indivíduo que em algum momento de sua vida liderou o processo de criação de uma empresa, desde a ideia até a formalização e sobrevivência aos três primeiros anos. Não será analisado o grau de inovação da empresa criada, uma vez que considera-se que toda nova empresa possui, em maior ou menor grau, alguma inovação, ou forma de fazer diferente o que já é encontrado no mercado. 


\subsubsection{Características dos empreendedores}

Um dos temas de estudo dos comportamentalistas que pesquisam sobre empreendedorismo são as características empreendedoras. Segundo Campos (2007) esses estudos “[...] procuram dimensionar ações e atitudes que diferenciem o empreendedor de outros seres humanos, destacando características pessoais que norteiam aqueles que desejam trabalhar por conta própria”. Para Fillion (1999) não é possível afirmar se uma pessoa será ou não bem-sucedida como empreendedora, mas é possível afirmar que ela tem as características comumente encontradas em empreendedores.

Dentre as pesquisas que buscaram definir as características empreendedoras Timmons et al (1977), listaram algumas, tais como: impulsividade e energia, autoconfiança, forte comprometimento, dinheiro, persistência na solução de problemas, definição de metas, disposição a correr riscos calculados, lidar com falhas, buscar o proporcionar feedbacks, tomar iniciativa e assumir responsabilidades, usar recursos, competir com seus próprios e padrões impostos, possuir autocontrole e, por fim, tolerar situações de ambiguidade e incerteza.

Fillion (1999) também dedicou-se aos estudos das características empreendedoras. Esse autor afirmou que a principal característica do empreendedor consiste em definir um objetivo (visão), e estar constantemente atento ao meio em que vive para identificar oportunidades. Além disso, o empreendedor toma decisões arriscadas necessárias para permanecer no caminho de concretizar sua visão. Enquanto continuar a imaginar, desenvolver e concretizar visões, o indivíduo continuará pela sua atuação agindo como empreendedor.

Com a apresentação desses dois autores, é possível constatar que existe uma grande quantidade de autores que se dedicaram a estudar especificamente as características empreendedoras. Salvo pequenas diferenças entre as características encontradas, todos obtiveram resultados semelhantes.

\subsubsection{A teoria de David McClelland}

No grupo dos que estudam o empreendedorismo pela ótica comportamentalista, um dos pioneiros, e até hoje mais respeitados estudiosos, é o psicólogo de Harvard, David McClelland. Seus estudos iniciados no final da década de 1950 procuravam entender os 
motivos que levam os empreendedores a agir para viabilizar a criação e sobrevivência de suas empresas.

Em 1961, McClelland publicou seu primeiro livro a tratar sobre o perfil do empreendedor, The Achieving society. Neste livro o autor relatou um estudo sobre o papel da necessidade de realização em toda a sociedade e identificou que ela era essencial para o crescimento econômico dos indivíduos. Segundo o autor, os indivíduos que tinham alta necessidade de realização (nAch) são mais motivados a empreender que os demais. Esse livro recebeu grande destaque e foi traduzido para o português em 1972.

McClelland (1961) contestava algumas afirmações existentes até então que diziam que o sucesso dos empreendedores era fruto unicamente de suas habilidades de gestão. Ele propôs que as habilidades e atitudes dos empreendedores também influenciavam suas ações. Seu estudo identificou 40 tipos de motivação para agir entre os indivíduos, os quais foram chamados de arquétipos.

Ao estudar os empreendedores, McClelland (1961) concluiu que eles possuíam uma estrutura motivacional diferente dos demais indivíduos, caracterizada pela presença de três tipos específicos de motivação: realização (n-Achievement), poder (n-Power) e afiliação (nAffiliation). O foco dos estudos de McClelland era a necessidade de realização, mas os outros dois tipos de motivação também apareceram em seus trabalhos, embora com menor ênfase.

Segundo McClelland (1961), o indivíduo com alta necessidade de realização, procura realizar coisas grandes. Ele tende a buscar objetivos com algum tipo de desafio, pois ama desafios e preocupa-se sempre em desempenhar bem suas atividades, sem esperar que as recompensas sejam apenas prestígio e dinheiro. Esse indivíduo procura se aperfeiçoar e progredir em seu desempenho e realizações, além de gostar de resolver problemas desafiadores. Ele procura testar seus limites e realizar bons trabalhos. Ele tende a se autodirigir, então é capaz de fazer sempre o que pretende. Seu desejo de realização é evidente em sua vida pessoal e profissional.

Devido à relevância que os estudos de McClelland alcançaram, o autor iniciou um projeto para estudos mais abrangentes sobre as características dos empreendedores. O projeto foi conduzido pela sua empresa de consultoria, a McBer Company e pela empresa Management System International (MSI) e financiado pela Agência para o Desenvolvimento Internacional 
dos Estados Unidos (United States Agency for International Development - USAID) (UNCTAD, 2013).

Esse projeto procurava determinar as características comportamentais que diferenciam os empreendedores de sucesso dos empreendedores com menos sucesso (UNCTAD, 2013). Segundo Matias (2010), McClelland (1987) desenvolveu medidas para testar as diversas características empreendedoras. Essa pesquisa tinha como ponto de partida a teoria das necessidades desenvolvida pelo próprio autor anos antes.

"A metodologia envolveu a realização de entrevistas focadas com aproximadamente 4 horas de duração com centenas de empreendedores em vários países.” (UNCTAD, 2013). Posteriormente os times de pesquisadores compararam as respostas, as discussões e o modo de pensar e se comportar dos diferentes grupos com a finalidade de entender o que existia realmente de diferente entre as competências pessoais, as ações e os pensamentos dos empreendedores de sucesso.

\footnotetext{
"Após meses de testes, os pesquisadores descobriram que existiam certas características que eram comuns, de um país para outro e de um negócio para outro, que todos os empreendedores de sucesso têm. Essas características foram nomeadas Personal Entrepreneurial Competencies (PEC)." (UNCTAD, 2013).
}

Foram dez as características identificadas, que foram traduzidas para o português como "Características do Comportamento Empreendedor (CCE)”. Essas características foram posteriormente agrupadas em três categorias: realização, planejamento e poder. Elas estão apresentadas no Quadro 1.

É interessante observar que os três grupos em que as características foram agrupadas (realização, planejamento e poder) são muito semelhantes aos três grupos apresentados nas pesquisas iniciais de McClelland (1961) sobre as motivações para empreender (realização, poder e afiliação), mas não são iguais.

Quadro 1 - Características do Comportamento Empreendedor

\section{REALIZAÇ̃̃O}

Pró-atividade (Busca de oportunidade e iniciativa)

O empreendedor é alguém que procura oportunidades. Onde outras pessoas veem problemas, os empreendedores veem oportunidade e tomam a iniciativa para transformar essas oportunidades em negócios lucrativos. Eles demonstram os seguintes comportamentos: 
- Fazer as coisas antes de ser mandado ou forçado pelas circunstâncias;

- Tomar ações para expandir a empresa para novas áreas, produtos ou serviços; e

- Perseguir oportunidades não convencionais para começar uma nova empresa, obter financiamentos, equipamentos ou assistência.

\section{Persistência}

Os empreendedores têm determinação para perseverar frente a obstáculos. Quando a maioria das pessoas tende a abandonar uma atividade, empreendedores perseveram. Eles demonstram os seguintes comportamentos:

- Agem para superar obstáculos e desafios;

- Agem com persistência, ou mudam para uma estratégia alternativa para superar um desafio ou obstáculo; e

- Se responsabilizam pessoalmente sobre o desempenho necessário para atingir objetivos.

\section{Comprometimento}

Os empreendedores sempre fazem o que disseram que fariam. Cumprem suas promessas, não importa quão grande seja o sacrifício pessoal. Eles demonstram os seguintes comportamentos:

- Fazem sacrifício pessoal e esforço extraordinário para completar um trabalho;

- Explicam aos empregados, ou até tomam seu lugar se necessário para ter um trabalho realizado; e

- Se esforçam para manter os clientes satisfeitos e colocam o bom relacionamento de longo prazo acima do ganho de curto prazo.

\section{Busca de qualidade e eficiência}

Tem a ver com paixão: ser obcecado pela necessidade de melhorar a qualidade, de fazer algo melhor, mais rápido ou mais barato. Essa paixão é refletida na integridade dos empreendedores e no orgulho que têm em seu trabalho. Eles demonstram os seguintes comportamentos:

- Encontrar maneiras de fazer as coisas melhor, mais rápido e mais barato;

- Agem para fazer coisas que atendam ou excedam padrões de excelência; e

- Desenvolvem e usam procedimentos para garantir que o trabalho está completo no tempo e que o trabalho atende os padrões de qualidade combinados.

\section{Acolhe riscos calculados}

Tomar riscos calculados é um dos conceitos primários do empreendedorismo, o elemento que os torna empreendedores. Eles estão dispostos a correr riscos. Eles demonstram os seguintes comportamentos:

- Calculam riscos deliberadamente e avaliam alternativas;

- Tomam ações para reduzir riscos e/ou controlar resultados; e

- Se colocam em situações que envolvem desafio ou risco moderado.

\section{PLANEJAMENTO}

\section{Orientado por objetivos}

Essa é a competência mais importante porque nenhuma das demais vai funcionar sem ela. Os empreendedores sabem o que querem. Eles sabem aonde estão indo nos negócios. Estão sempre pensando sobre o futuro e definindo objetivos. Eles demonstram os seguintes comportamentos:

- Definem metas e objetivos que são relevantes pessoalmente e desafiadores;

- Definem metas específicas e claras de longo prazo; e

- Definem objetivos mensuráveis de curto-prazo.

Pesquisador de informações

Os empreendedores não gostam de incerteza. Eles não gostam de contar com os outros para obter informações. Isso significa que empreendedores gastam muito tempo buscando informações sobre seus clientes, fornecedores, tecnologias e oportunidades. Eles demonstram os seguintes comportamentos:

- Busca pessoalmente informações de consumidores, fornecedores e concorrentes;

- Fazem pessoalmente pesquisas em como fabricar um produto ou serviço; e

- Consultam especialistas para conselhos técnicos e de negócios.

Planejador e controlador

Sistemático significa "de uma maneira lógica e ordenada". Planejar é decidir o que você irá fazer. Monitorando as metas. É, de fato, para que serve um plano de negócios: enxergar se algo é viável antes de tentar isso. Empreendedores demonstram os seguintes comportamentos:

- Planejam quebrando grandes tarefas em sub-tarefas com horizontes de tempo claro;

- Revisam o plano procurando feedback sobre o desempenho ou circunstâncias para mudar; e

- Guardam dados financeiros e os usam para tomar decisões.

\section{PODER}

Persuasivo e sustentador de redes de contatos 
Os empreendedores usam uma estratégia definida para influenciar as outras pessoas a segui-los ou a fazer algo para eles. Uma estratégia de persuasão depende de todas as partes envolvidas, isto é, os empreendedores e as pessoas que ele está tentando persuadir. Empreendedores demonstram os seguintes comportamentos:

- Usam estratégias deliberadas para influenciar e persuadir outros;

- Usam pessoas chave como agentes para atingir os próprios objetivos; e

- Agem para desenvolver e manter uma rede de contatos de negócios.

Independência e autoconfiança

Essa competência está relacionada à segurança que o empreendedor tem em sua capacidade ou potencial para fazer alguma coisa. É uma confiança interna que é refletida pelos desafios que eles escolhem enfrentar em sua vida. Sendo autoconfiante significa assumir total responsabilidade por fazer as coisas acontecerem. Eles demonstraram os seguintes comportamentos:

- Buscam autonomia a partir das regras e/ou controlar outras pessoas;

- Atribuem as causas do sucesso e do fracasso a si próprio e à sua própria conduta; e

- Expressam confiança em sua habilidade para completar uma tarefa difícil ou superar um desafio.

FONTE: UNCTAD, 2013.

Segundo Matias (2010) além das dez características apresentadas no Quadro 1, McClelland (1987) ainda identificou outras características que haviam sido relacionadas em literatura prévia, mas que não obtiveram comprovação de que os empreendedores de sucesso as possuíam quando comparados aos demais empreendedores. Todavia essas características estavam presentes e poderiam distinguir empreendedores de não-empreendedores.

O instrumento desenvolvido por McClelland é até hoje um dos principais instrumentos para identificação de características empreendedoras e por isso é utilizado no programa Empretec (Programa de desenvolvimento do empreendedorismo), cujo objetivo é:

\footnotetext{
"Aumentar a capacidade produtiva e a competitividade internacional para o benefício do desenvolvimento econômico, erradicação da pobreza e participação igual dos países em desenvolvimento na economia mundial" (UNCTAD, 2013).
}

Esse programa promove a mudança de comportamento em um grupo seleto de empreendedores promissores, ajudando-os a colocar suas ideias em ação e consequentemente ajudando empresas incipientes a crescer (UNCTAD, 2013).

Segundo o relatório anual de 2011, o Empretec foi lançado em 1988 na Argentina e, desde então, se expandiu para 32 países em desenvolvimento e aguardava para ser implantado em mais 27 países. O projeto é gerenciado pela United Nations Conference on Trade and Development (UNCTAD) por meio do Programa das Nações Unidas para o Desenvolvimento (PNUD). Aplicado com parceiros locais, o programa já assistiu mais de 240.000 empreendedores. No Brasil o programa existe desde 1993, em parceria com o Serviço de 
apoio às micro e pequenas empresas (SEBRAE), e já treinou mais de 160.000 empreendedores (UNCTAD, 2011).

Nesta tese, optou-se por utilizar o instrumento de David McClelland para medir as características empreendedoras por entender ser esta a ferramenta mais adequada. Embora outros instrumentos tenham sido desenvolvidos, até mesmo propondo uma evolução do instrumento de David McClelland, eles ainda não possuem a mesma abrangência e replicabilidade.

\subsection{O processo de criação de novas empresas (Processo empreendedor)}

O processo empreendedor tem sido tema de pesquisa da área de empreendedorismo desde a década de 1980. Dentre os estudos existentes, é possível identificar linhas de pensamento distintas com pontos de divergência e de convergência entre os autores.

Estudar o processo empreendedor é importante para entender o fenômeno do empreendedorismo. Moroz e Hindle (2012 p.785) acreditavam que estudar o empreendedorismo como um processo é adequado, pois “ele é um fenômeno baseado na ação que envolve criatividade, estratégia e organização".

Nesta pesquisa, entender e descrever o processo empreendedor são importantes, visto que se pretende resgatar as informações fornecidas pelos empreendedores sobre quais foram as ações que eles realizaram durante a condução deste processo. Para Hisrich et al (2005) estudos sobre o processo empreendedor buscam responder o que os empreendedores fazem e como fazem, ou seja, mostrar as ações do empreendedor para criar uma organização.

Outro autor que associou o processo empreendedor às ações para criação de uma empresa foi Bygrave (2004, p.7), para quem o processo empreendedor envolve "todas as funções, atividades, e ações associadas com as oportunidades percebidas" para ofertar e comercializar no mercado um produto ou serviço. Nesse caso é possível observar que o processo empreendedor tem início antes mesmo da criação da empresa, estando associado também à percepção das oportunidades. 
Para entender o processo empreendedor é preciso conhecer o que é processo. Segundo Harrington (1993 p.10), processo é "Qualquer atividade que recebe uma entrada (input), agrega-lhe valor e gera uma saída (output) para um cliente interno ou externo.”. Dessa forma, é possível afirmar que o processo empreendedor tem como entrada uma ideia ou algumas ideias, às quais durante o processo são agregados outros fatores tais como recursos financeiros, humanos, materiais, entre outros, até resultarem em uma empresa estabelecida e posteriormente operando no mercado.

Em estudo pioneiro realizado no Brasil durante sua tese de doutorado, Santos (1983) definiu que o processo de criação de uma empresa industrial pode ser dividido em quatro etapas, as quais nomeou de maneira semelhante à evolução de um ser humano, a saber: concepção, gestação, nascimento, e pré-infância. Essa sequência pode ser observada na Ilustração 1.

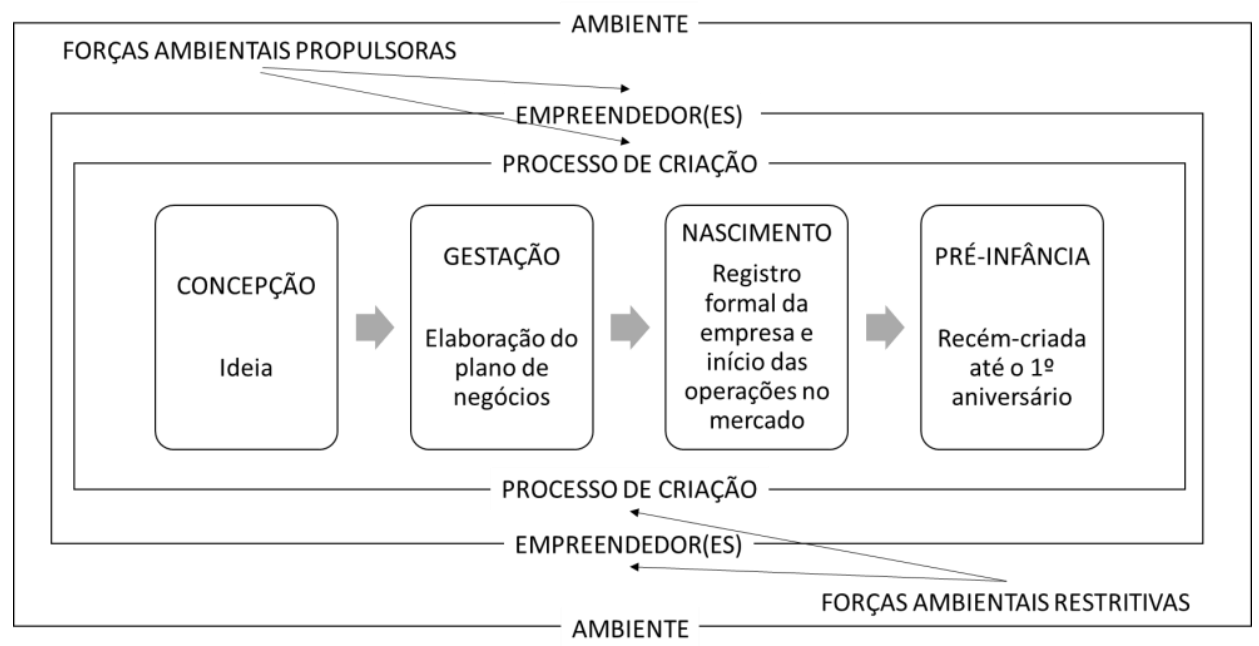

Ilustração 1 - Modelo de processo empreendedor

FONTE: SANTOS, 1983 (aprimorado pelo autor)

Santos (1983) entendia que o processo de criação da empresa é fruto da ação de empreendedores e que tanto esses quanto o próprio processo de criação de empresas são influenciados por forças ambientais propulsoras ou restritivas. É possível entender que o processo empreendedor conta com 3 elementos: o ambiente, o empreendedor e o processo de criação de empresas.

Santos (1983) ainda detalhou as atividades que ocorrem em cada uma das etapas do processo de criação da empresa: 


\begin{abstract}
"Etapa 1 Concepção: Surgimento da ideia de criação da empresa, acompanhada da respectiva decisão do empreendedor de iniciar as ações neste sentido.

Etapa 2 Gestação: Elaboração de todo o processo formal, incluindo decisões sobre a forma jurídica, localização, ramo, avaliação de recursos necessários, viabilidade de produção e de mercado, dentre outras.

Etapa 3 Nascimento: Aprovação formal do processo constitutivo da nova empresa pelos órgãos legais que regulam a atividade empresarial de caráter industrial.

Etapa 4 Pré-infância: Período que compreende desde a data de realização da primeira transação da empresa com seu mercado, até o seu primeiro aniversário de fundação. Este período foi arbitrariamente demarcado, em função dos objetivos iniciais que se pretende atingir na pesquisa." (SANTOS, 1983)
\end{abstract}

$\mathrm{Na}$ mesma época dos estudos de Santos, Gartner (1985) procurou criar um modelo que descrevesse a criação de novos negócios observando toda a teoria existente até então. $\mathrm{O}$ modelo que foi proposto por Gartner (1985, p.698) está demonstrado na Ilustração 2 e possui as mesmas três variáveis propostas por Santos (1983) (o empreendedor, o ambiente e o processo de criação da empresa), além de adicionar, como uma variável, a própria organização que foi criada.

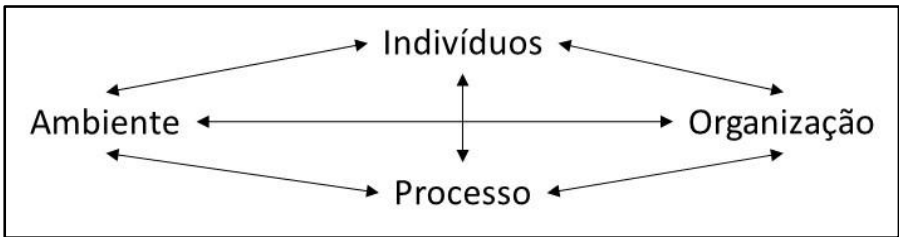

Ilustração 1 - Modelo de processo empreendedor FONTE: GARTNER, 1985, p. 698

Embora muito semelhante nas variáveis do processo, os modelos de Gartner (1985) e Santos (1983) apresentam divergências em outros pontos. Para Santos (1983) as setas indicam influência, para Gartner (1985) elas representam relação. Santos (1983) não se preocupou em analisar o indivíduo, a quem chamou de empreendedor, já Gartner (1985) indicava que deveriam ser analisadas as suas características.

Em relação às etapas do processo empreendedor, ambos também possuem diferenças em seus modelos. O modelo de Santos (1983) propõe quatro etapas, enquanto que Gartner (1985) propõem seis etapas (a ordem das etapas não implica uma sequência de ações), a saber: 1) Identificar a oportunidade, 2) mobilizar recursos, 3) colocar o produto ou serviço no mercado, 4) produzir o produto, 5) construir uma organização, 6) responder ao governo e à sociedade. Gartner (1985) não descreveu cada uma das etapas do processo, apenas as enumerou. 
Mais recentemente Moroz e Hindle (2012) identificaram que os estudos que procuravam definir o processo empreendedor eram muito variados, uma vez que diferentes autores apresentavam processos muito distintos em busca de oferecer uma contribuição adequada à teoria. Buscando encontrar um modelo mais adequado os autores analisaram todos os principais journals acadêmicos e livros didáticos publicados nos quarenta anos que os precederam e publicaram em seus artigos modelos de processo empreendedor. Foram encontrados mais de cem artigos ou livros, que os autores posteriormente reduziram a trinta e dois trabalhos ao eliminar redundâncias e verificar se o foco do modelo proposto era mesmo o processo empreendedor. A análise realizada pretendia encontrar as semelhanças entre os processos e também entender como eles se distinguem de outros processos propostos por outras linhas de estudo, que não a de empreendedorismo.

A pesquisa de Moroz e Hindle (2012) mostrou que nenhum dos modelos analisados conseguiu ser genérico (cobrir uma vasta gama de contextos e atividades empreendedoras) e distinto (genuinamente focado em atividades que podem ser demonstradas como únicas do empreendedorismo). Os estudos eram sempre heterogêneos e por isso não foi possível definir um único modelo de processo empreendedor. Dos trinta e dois modelos analisados por Moroz e Hindle (2012), quatro foram considerados como convergentes, pois eram simultaneamente genéricos e distintos. Foram eles Gartner (1985), Bruyat e Julien (2000), Sarasvathy (2006) e Shane (2003). O modelo de Gartner (1985) já foi apresentado nesta tese e os demais serão apresentados em detalhes mais adiante.

Para Bruyat e Julien (2000) o empreendedor é o indivíduo que é responsável pelo processo de criação de uma nova empresa. A criação de valor, por sua vez, é parte de um processo. Após a criação da empresa existe uma constante troca de experiências e informações entre o indivíduo e o novo valor criado. Como pode ser observado na Ilustração 3, os autores consideravam o ambiente, o empreendedor (indivíduo), a empresa (NVC new value created) e o processo. A inovação desse modelo consiste na realimentação do indivíduo pelo novo valor criado, ou seja, é um processo dinâmico de troca de informações. Os autores também se diferenciam dos demais pois entendem que o empreendedor só pode ser assim chamado após a criação da inovação ou da empresa. Bruyat e Julien (2000) não definiram etapas para o processo de criação da empresa, como feito por outros autores. 


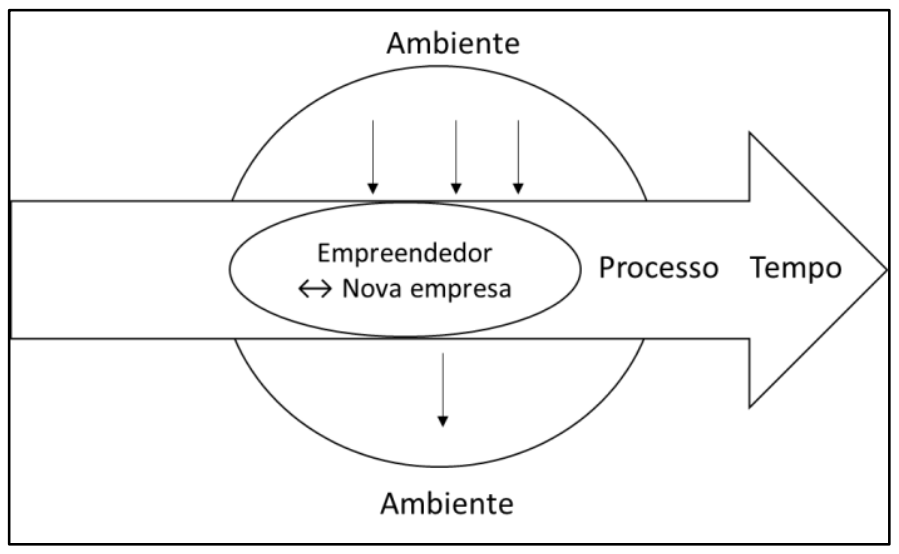

Ilustração 2 - Modelo de processo empreendedor FONTE: BRUYAT e JULIEN, 2000, p.170.

Outro modelo de processo empreendedor destacado por Moroz e Hindle (2012) foi o de Sarasvathy (2006). Nesse caso, o modelo não foi assim considerado pela autora, mas sim proposto a partir do que Moroz e Hindle (2012) definiram segundo suas análises de Sarasvathy (2001a e 2006). O modelo como pode ser observado na Ilustração 4 , é focado no empreendedor e não apresenta um processo de criação de uma nova empresa, além de focar em um momento anterior ao da criação efetiva de um novo empreendimento. É possível identificar que o modelo preocupa-se também com recursos e com o ambiente, embora de maneira muito superficial.

A inovação apresentada pelo modelo da Sarasvathy (2001a e 2006) para o processo empreendedor foi o fato de propor que não existe planejamento prévio pelo empreendedor, ou seja, as atividades simplesmente vão acontecendo ao longo do tempo.

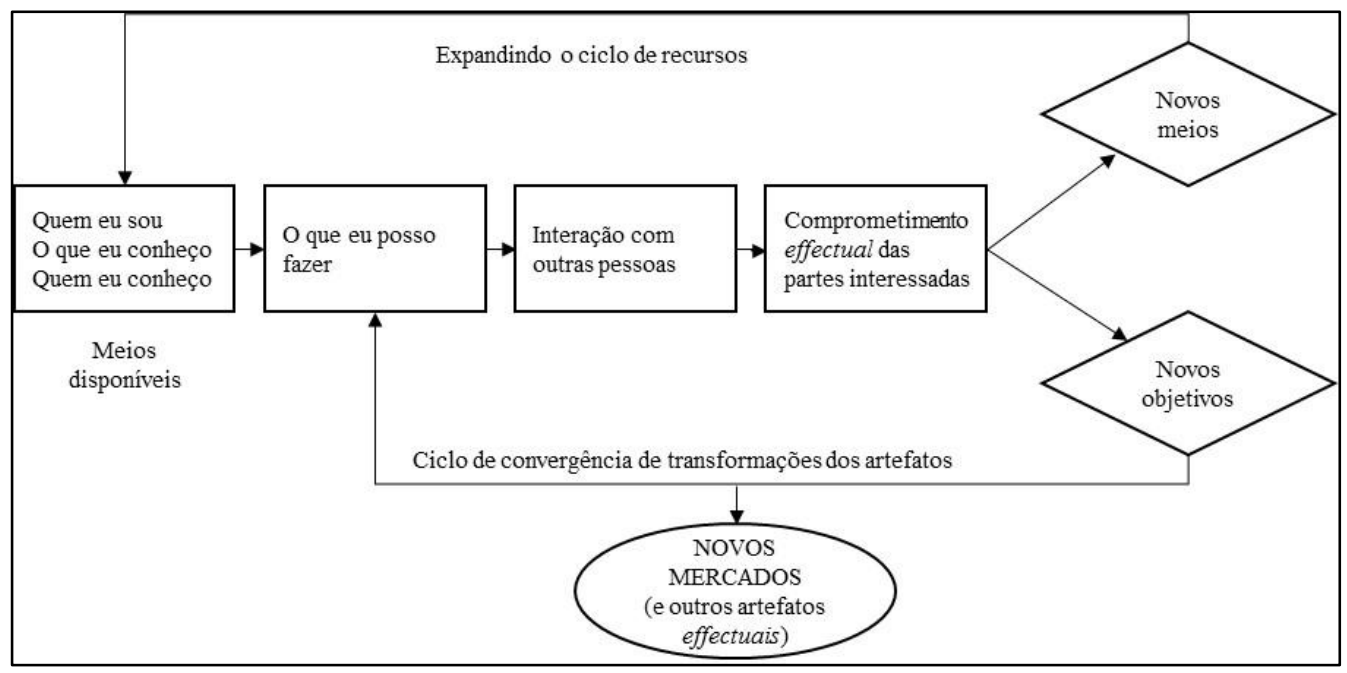

Ilustração 3 - Modelo de processo empreendedor

FONTE: Adaptado de SARASVATHY, 2001 a e 2006 por MOROZ e HINDLE, 2012, p.805. 
O último dos modelos que recebeu destaque na pesquisa de Moroz e Hindle (2012) foi o proposto por Shane (2003), para quem o processo empreendedor tem dois grandes influenciadores, o indivíduo e o ambiente, como pode ser observado na Ilustração 5. Essas variáveis se relacionam com um processo principal que passa pela descoberta da oportunidade, sua exploração e a consequente execução da nova empresa. As características do ambiente e do indivíduo influenciam em cada uma das etapas desse processo: a existência de uma oportunidade, a descoberta das oportunidades e a exploração da oportunidade (aquisição de recursos, estratégia, organização, e eventualmente desempenho).

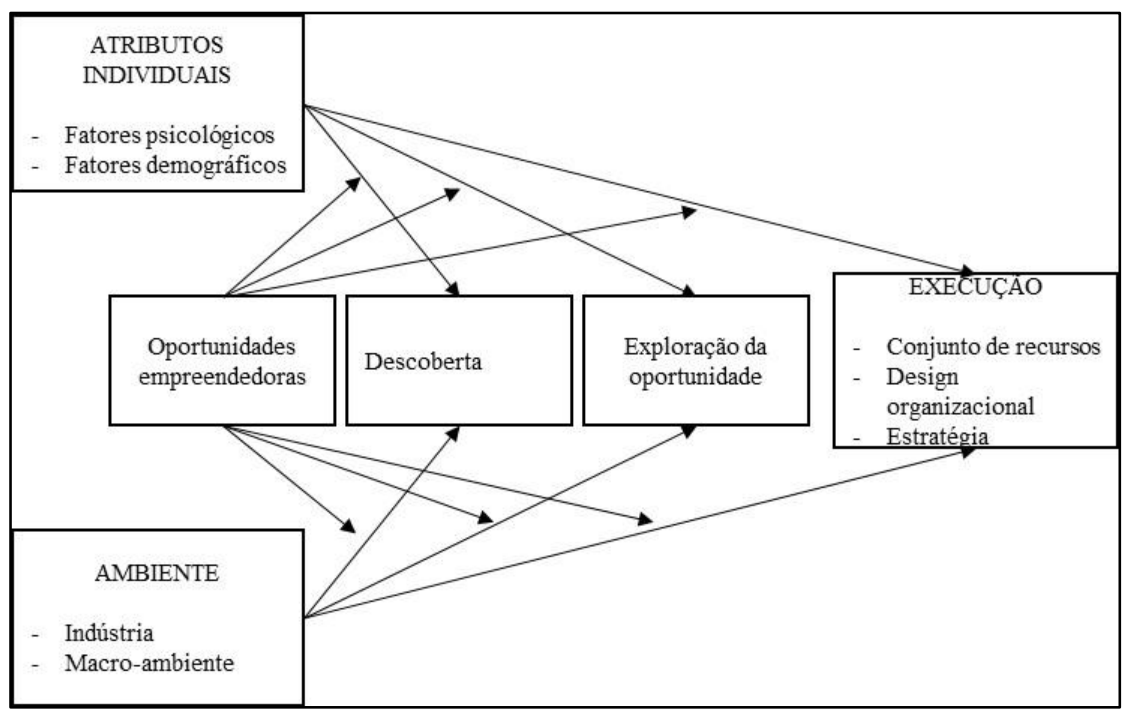

Ilustração 4 - Modelo de processo empreendedor FONTE: SHANE, 2003, p.11.

Embora não faça parte das análises de Moroz e Hindle (2012), Shane (2003) também definiu um processo mais centrado nas etapas que um empreendedor percorre para a criação de uma nova empresa. Esse processo está demonstrado na Ilustração 6.

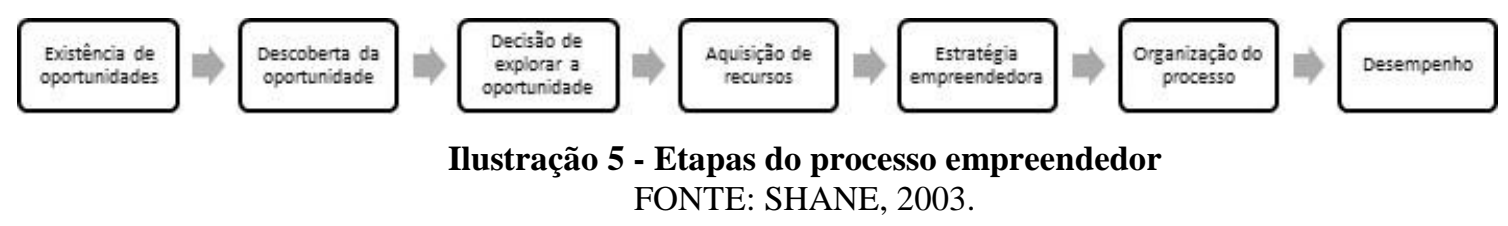

Na Ilustração 6 é possível observar que o processo empreendedor tem início com a percepção de que existe uma oportunidade, que é posteriormente descoberta por indivíduos que estão 
atentos (empreendedores) e desenvolvem ideias de como aproveitá-las. O indivíduo deve decidir se irá ou não explorar determinada oportunidade. Caso resolva explorá-la, ele inicia uma ação para mobilizar os recursos que são necessários e a definição de uma estratégia e organização para explorar a oportunidade identificada. Uma vez que a empresa foi iniciada para explorar a oportunidade, o empreendedor analisa constantemente seu desempenho.

Além dos modelos que receberam destaque na pesquisa de Moroz e Hindle (2012), neste estudo analisaram-se outros modelos que são muito citados em pesquisas acadêmicas e por isso também merecem destaque. Um desses modelos é o de Bhave (1994), criado com base em entrevistas realizadas com vinte e sete empreendedores que haviam criado empresas industriais na região de Nova York. Esse modelo define como etapas do processo empreendedor o reconhecimento da oportunidade (estimulada internamente ou externamente), o compromisso com uma criação física, o set-up da tecnologia de produção, a criação de uma organização, a criação do produto, a ligação com o mercado e o feedback dos consumidores. Para facilitar o entendimento do processo, o autor optou por dividi-lo em três estágios, o estágio da oportunidade, o estágio do set-up da tecnologia e criação da organização e o estágio da livre troca. Conceito do negócio, tecnologia de produção e produto são respectivamente as principais variáveis que representam os três estágios.

Diferentemente de alguns dos modelos apresentados anteriormente nessa revisão, o foco do modelo de Bhave (1994) é no processo de criação da empresa e por isso não inclui outras variáveis como ambiente ou o empreendedor.

O primeiro estágio do modelo de Bhave (1994) pode ser observado na Ilustração 7 e vai do reconhecimento da existência de uma oportunidade até o compromisso dos empreendedores em criar uma empresa (comprometer recursos físicos). Logo de início, é possível observar que o modelo difere de todos os demais analisados, uma vez que o autor propõe duas maneiras distintas para o início do processo durante o reconhecimento da oportunidade, podendo essa ser estimulada internamente ou externamente. 


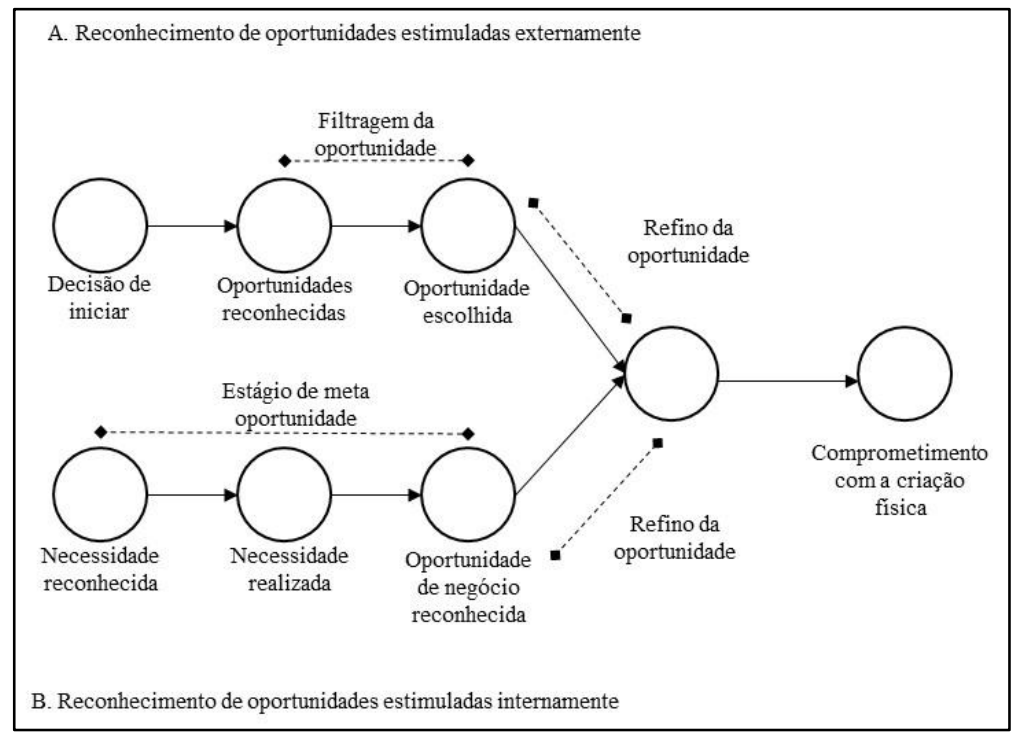

Ilustração 6 - Etapas iniciais do processo empreendedor FONTE: BHAVE, 1994, p.229.

Para os empreendedores que Bhave (1994) identificou que reconhecem oportunidades estimuladas externamente, o reconhecimento da oportunidade precede a decisão de começar a empresa. À medida que percebem necessidades não atendidas, eles tentam buscar suas próprias soluções para atendê-las. Nesse estágio ainda não se sabe se atender à necessidade é ou não uma oportunidade. Uma vez que a solução é encontrada, as possibilidades de negócio ficam aparentes. Ao longo do tempo, as possibilidades de negócio ficam atrativas e a decisão de começar a empresa é tomada.

Já para os empreendedores identificados por Bhave (1994) como os que reconhecem oportunidades internamente, o primeiro estímulo para empreender é de caráter pessoal, onde o indivíduo decide ser empreendedor e a partir disso passa a buscar oportunidades. A decisão é influenciada por circunstâncias pessoais e do ambiente do empreendedor naquele momento. A decisão de começar a empresa é seguida por uma busca para alinhar o conhecimento, experiência, habilidades e outros recursos do empreendedor com as necessidades do mercado.

Uma vez que o compromisso de perseguir uma oportunidade em particular é assumido, o empreendedor procura refinar a oportunidade e as etapas do processo para os dois tipos de empreendedor passam a ser iguais. A primeira etapa do processo, quando ele é unificado, é a identificação do conceito do negócio. Essa identificação é a evidência de que foram completados com sucesso os sub-processos de filtragem, seleção e refino da oportunidade. Uma vez que os empreendedores tenham focado nos seus respectivos conceitos de negócio, 
podem facilmente articular aspectos de sua empresa que irão distingui-la das outras que atuam no mesmo setor (BHAVE, 1994).

Após a identificação do conceito do negócio o empreendedor precisa de recursos, físicos e de outra natureza, para levar à frente a oportunidade. Logo uma organização precisa ser criada e tecnologia de produção definida para transformar o conceito do negócio em um produto vendável - esse é o objetivo do segundo estágio do processo. A decisão de buscar e investir recursos para criar uma empresa é um estágio significativo no processo de criação de empresas. O set-up da tecnologia de produção e a criação da empresa seguem o compromisso da criação física, como pode ser observado na Ilustração 8. O compromisso da criação física pode envolver desde uma empresa que comece pequena até grandes investimentos ou capital de terceiros (BHAVE, 1994).

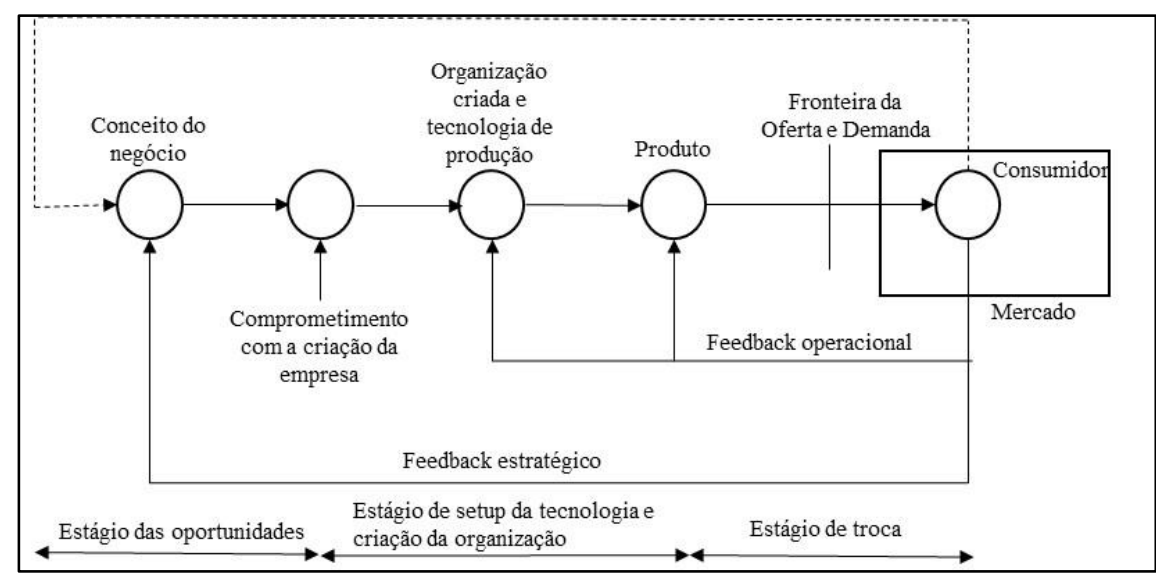

Ilustração 7 - Etapas finais do processo empreendedor FONTE: BHAVE, 1994, p.235

A criação da organização ocorre em paralelo com o set-up da tecnologia de produção para todas as empresas. Por criação da organização entende-se a criação da estrutura física, assim como os processos organizacionais (BHAVE, 1994).

A passagem para o último estágio do modelo ocorre com a criação do produto, que deve satisfazer as necessidades do consumidor. $\mathrm{O}$ empreendedor analisa o consumidor e pode, em alguns casos, fazer mudanças do conceito do negócio para o produto. As fronteiras da demanda e da oferta são a próxima barreira dos empreendedores (BHAVE, 1994). 
O último estágio da criação de uma empresa são a ligação com o mercado e a ação que os empreendedores tomam a partir do feedback dos consumidores, que pode indicar necessidade de mudança em qualquer um dos estágios anteriores (BHAVE, 1994).

Bhave (1994) afirma ainda que o processo não é sempre tão linear, alguns empreendedores, por exemplo, só se comprometem com a criação da empresa quando já contam com alguns consumidores. A barreira é ainda maior para empreendedores que contam com conceitos de negócios inovadores.

Dentre os pesquisadores brasileiros, após o modelo proposto por Santos (1983) não houve outro estudo de relevância que tratasse especificamente do processo empreendedor. Os autores brasileiros, Dornelas (2008) e Mariano e Mayer (2008), em seus livros sobre empreendedorismo, analisaram o processo empreendedor proposto por Moore (1986), que pode ser visto na Ilustração 9.

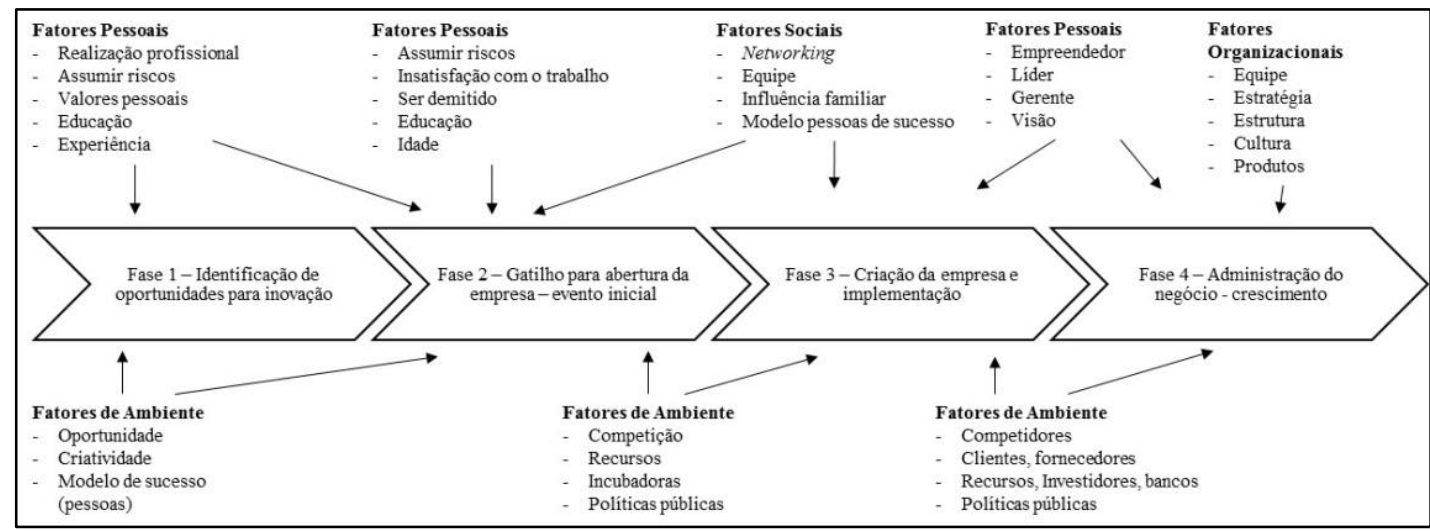

Ilustração 8 - Modelo de processo empreendedor

FONTE: Adaptado de MOORE, 1986 por DORNELAS, 2008.

O modelo de processo empreendedor de Moore (1986) propõe 4 etapas bem definidas: 1) Identificação de oportunidade para inovação; 2) gatilho para abertura da empresa - evento inicial; 3) criação da empresa e implementação; e 4) administração do negócio. Além disso, Moore (1986) analisa as variáveis pessoais, sociais, do ambiente e organizacionais que ocorrem e podem afetar as diversas fases do processo.

O modelo de Moore (1986) também foi o modelo de processo empreendedor proposto por Bygrave e Zacharakis (2010). Além deste modelo, os autores acrescentaram as variáveis pessoal, sociológica e do ambiente, que em sua visão influenciam o processo. Aspectos 
pessoais e ambientais como influenciadores do processo são semelhantes ao que outros autores já citados anteriormente propuseram. Especificamente a variável sociológica foi proposta unicamente por Bygrave e Zacharakis (2010), entretanto, se for analisado, o que os autores consideram como variáveis inerentes a pessoa empreendedora, como, por exemplo, família, idade, experiência, entre outros, pode-se entender a variável sociológica também estava presente no que outros autores caracterizaram como variáveis pessoais.

Dornelas (2008) também analisou o modelo de processo empreendedor proposto por Hisrich et al (2005), que prevê a existência de 4 etapas distintas bem definidas. Segundo Hisrich et al (2005), embora essas etapas sigam uma sequência, nenhuma delas é realizada isoladamente ou considerada totalmente completa antes de começar o trabalho em outras.

A primeira etapa, nomeada identificação e avaliação da oportunidade, inicia com o empreendedor estando alerta para as possibilidades existentes ou com o uso de mecanismos para identificar uma oportunidade. Na maioria dos casos os empreendedores não utilizam mecanismos formais para identificar a oportunidade. Uma vez que a oportunidade foi identificada, a próxima atividade do empreendedor, que é uma das mais críticas, é avalia-la. Nesse momento o empreendedor deve descobrir se o produto vai ou não oferecer o retorno adequado em comparação com os recursos necessários para explorá-lo. É importante que o empreendedor analise também se a oportunidade é adequada às suas habilidades e objetivos (HISRICH et al, 2005).

A segunda etapa recebe o nome de desenvolvimento do plano de negócios. A principal atividade dessa etapa é a elaboração de um plano de negócios que irá desenvolver e guiar a oportunidade a ser explorada (HISRICH et al, 2005).

A terceira etapa é a de determinar os recursos necessários. Nessa etapa o empreendedor deve analisar os recursos que possui e avaliar se serão suficientes para o negócio. Caso não sejam, ele pode buscar recursos externos (HISRICH et al, 2005).

A quarta e última etapa consiste na gestão da empresa resultante. Nesse momento as atividades do empreendedor visam a usar os recursos adquiridos para implementar o plano de negócios que desenvolveu. Para tanto, ele deve implementar sistemas de controle que possam rapidamente identificar problemas e resolvê-los (HISRICH et al, 2005). 
Em todos os modelos de processo empreendedor analisados no presente estudo é possível identificar que existem o processo principal e as variáveis que o influenciam. Após analisar todos os modelos de processo empreendedor propostos, conforme observado no Quadro 2, concluiu-se que não existe ainda na literatura sobre empreendedorismo um modelo único que esteja confirmado e consolidado pelos pesquisadores que possa ser utilizado neste estudo.

Quadro 2 - Modelos de Processo empreendedor

\begin{tabular}{|c|c|c|}
\hline Autor & Variáveis & Etapas \\
\hline \multirow{4}{*}{ Santos (1983) } & \multirow{4}{*}{ Ambiente, empreendedor, processo } & 1) Concepção \\
\hline & & 2) Gestação \\
\hline & & 3) Nascimento \\
\hline & & 4) Pré-infância \\
\hline \multirow{6}{*}{ Gartner (1985) } & \multirow{6}{*}{$\begin{array}{l}\text { Ambiente, empreendedor, } \\
\text { organização, processo }\end{array}$} & 1) Identificar a oportunidade \\
\hline & & 2) Mobilizar recursos \\
\hline & & 3) Colocar o produto ou serviço no mercado \\
\hline & & 4) Produzir o produto \\
\hline & & 5) Construir uma organização \\
\hline & & 6) Responder ao governo e à sociedade \\
\hline $\begin{array}{c}\text { Bruyat e Julien } \\
(2000)\end{array}$ & $\begin{array}{l}\text { Ambiente, empreendedor, empresa, } \\
\text { processo }\end{array}$ & Não foram definidas etapas \\
\hline $\begin{array}{l}\text { Sarasvathy (2001a e } \\
\text { 2006) }\end{array}$ & Ambiente, empreendedor, recursos & Não foram definidas etapas \\
\hline \multirow{7}{*}{ Shane (2003) } & \multirow{7}{*}{ Ambiente, empreendedor, processo } & 1) Existência da oportunidade \\
\hline & & 2) Descoberta da oportunidade \\
\hline & & 3) Decisão de explorar a oportunidade \\
\hline & & 4) Aquisição de recursos \\
\hline & & 5) Definição da estratégia empreendedora \\
\hline & & 6) Organização do processo \\
\hline & & 7) Análise e manutenção do desempenho \\
\hline \multirow{6}{*}{ Bhave (1994) } & \multirow{6}{*}{ Processo de criação } & 1) Identificação da oportunidade \\
\hline & & 2) Refinamento da oportunidade \\
\hline & & 3) Identificação do conceito de negócio \\
\hline & & 4) Compromisso com a criação física \\
\hline & & $\begin{array}{l}\text { 5) Criação da organização e set-up da tecnologia } \\
\text { de produção }\end{array}$ \\
\hline & & $\begin{array}{l}\begin{array}{l}\text { Criação do produto que satisfaça o } \\
\text { consumidor }\end{array} \\
\end{array}$ \\
\hline \multirow{4}{*}{ Moore (1986) } & \multirow{4}{*}{$\begin{array}{l}\text { Ambiente, empreendedor, empresa, } \\
\text { processo }\end{array}$} & 1) Identificação da oportunidade \\
\hline & & 2) Gatilho para abertura da empresa \\
\hline & & 3) Criação da empresa e implementação \\
\hline & & 4) Administração do negócio \\
\hline \multirow{4}{*}{ Hisrich et al (2005) } & \multirow{4}{*}{ Processo de criação } & 1) Identificação da oportunidade \\
\hline & & 2) Desenvolvimento do plano de negócios \\
\hline & & 3) Determinação dos recursos \\
\hline & & 4) Gestão da empresa \\
\hline
\end{tabular}


Optou-se por adotar um modelo de processo empreendedor elaborado pelo autor desta tese, partir da análise de todos os modelos do Quadro 2. Esse modelo é apresentado na Ilustração10.

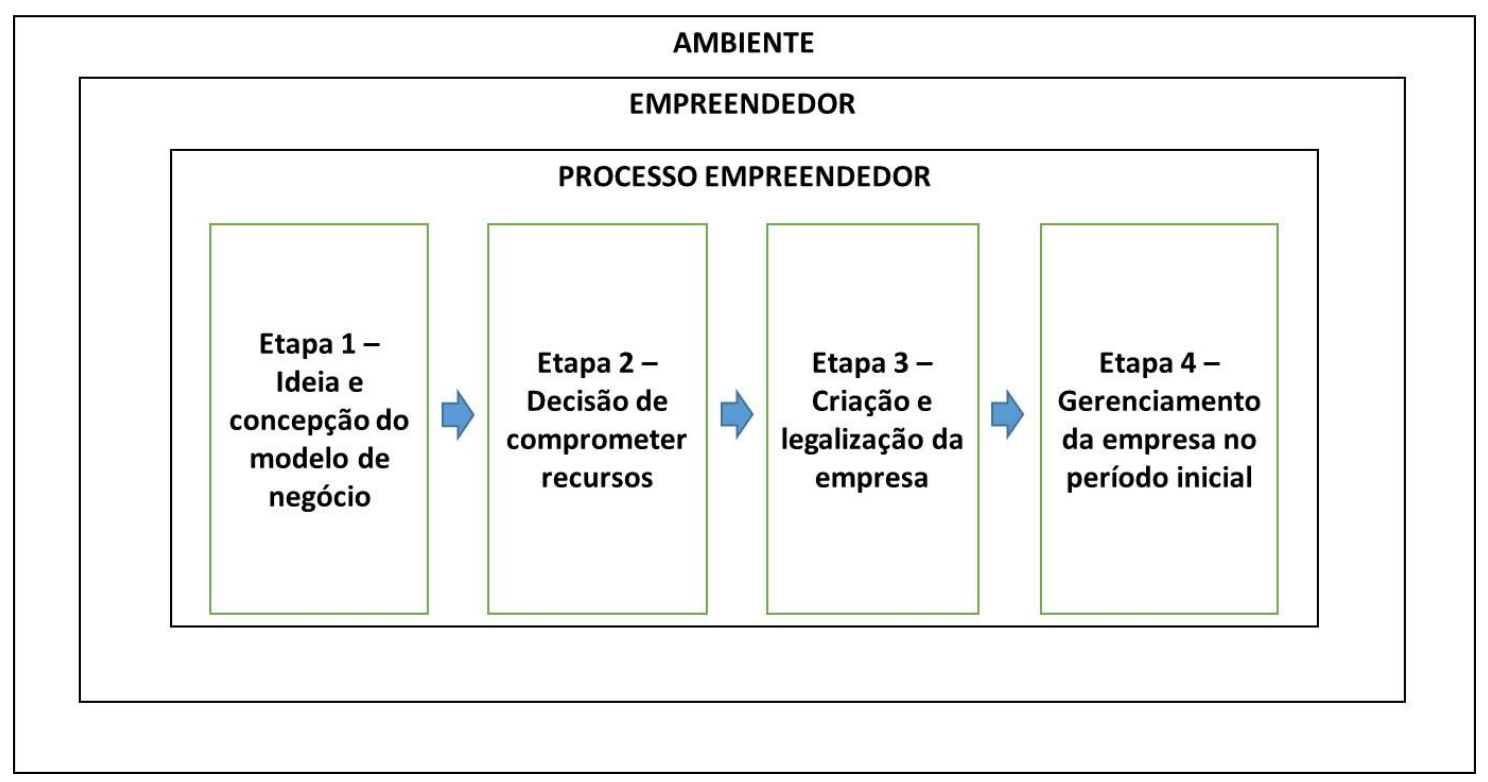

Ilustração 9 - Modelo de processo empreendedor proposto pelo autor.

FONTE - Elaborado pelo autor

É possível observar que o modelo proposto conta com três variáveis, o processo, o empreendedor e o ambiente. A maioria dos autores analisados também trabalhava com essas mesmas três variáveis. Alguns autores incluíam a empresa, como dimensão, no entanto, optou-se por não incluí-la no modelo, uma vez que acredita-se que a empresa é o resultado final esperado do processo empreendedor, e não parte integrante do mesmo.

O empreendedor é o agente do processo, ou seja, é o responsável por conduzir todo o processo, desde a ideia até o estabelecimento da empresa. É importante destacar que o próprio empreendedor sofre uma mudança durante o processo, uma vez que só pode ser considerado efetivamente empreendedor após a criação da empresa, que ocorre ao longo do processo.

A outra variável que afeta o processo é o ambiente. Essa variável afeta tanto o processo de criação da empresa quanto o próprio agente da empresa, ou seja, o empreendedor. Isso significa que variações no ambiente podem estimular ou inibir os empreendedores a participar do processo empreendedor e também podem afetar a maneira como o processo ocorre. 
Segundo Harrington (1993, p.35) os processos podem ser divididos em sub-processos, que por sua vez, são constituídos de várias atividades, que são as ações necessárias para produzir um resultado em particular. "Elas são as ações necessárias para produzir um resultado particular". Essas atividades podem ainda ser divididas em tarefas.

No modelo proposto neste estudo o processo de criação da empresa foi dividido em quatro sub-processos, assim como já havia sido feito por autores anteriores, conforme exposto no Quadro 2. O primeiro sub-processo inicia-se no momento que o indivíduo tem uma ideia e passa pela concepção de um modelo de negócios. O segundo sub-processo tem início no momento que o indivíduo decide comprometer recursos próprios e/ou de terceiros para implementar seu conceito de negócio. O terceiro sub-processo inicia-se com a criação e legalização da empresa e o quarto sub-processo consiste no gerenciamento da empresa em seus primeiros três anos de existência.

Uma vez que foram definidos os sub-processos do processo de criação da empresa, buscou-se definir as atividades que devem acontecer dentro de cada sub-processo desse processo, para que exista a criação da empresa e, posteriormente, sua sobrevivência aos primeiros anos (os mais críticos para a sua sobrevivência). Essas atividades foram definidas pelo próprio pesquisador a partir da observação de empreendedores que passaram por esse processo e ratificadas com especialistas. Elas estão descritas no Quadro 3.

Quadro 3 - Atividades do processo empreendedor

\begin{tabular}{|l|}
\hline SUBPROCESSO 1: Ter a ideia / Definir o conceito do negócio \\
\hline Atividade empreendedora \\
\hline Ter a ideia inicial \\
\hline Definir o conceito do negócio \\
\hline Adaptar o conceito de negócio às exigências dos stakeholders \\
\hline Buscar informações de mercado \\
\hline Buscar informações de concorrentes \\
\hline Definir os segmentos de clientes que serão atendidos \\
\hline Fazer o plano de negócios \\
\hline Buscar aprender sobre o negócio e gestão \\
\hline SUBPROCESSO 2: Comprometer recursos \\
\hline Atividade empreendedora \\
\hline Dedicar seu tempo à empresa \\
\hline Desenvolver o produto/serviço \\
\hline Fazer planejamento financeiro \\
\hline Buscar investimento \\
\hline Investir capital próprio \\
\hline Buscar recursos de terceiros (investidores, clientes e fornecedores) \\
\hline
\end{tabular}




\begin{tabular}{|l|} 
Buscar sócios \\
\hline SUBPROCESSO 3: Criar a empresa \\
\hline Atividade empreendedora \\
\hline Proteger a propriedade intelectual \\
\hline Adquirir máquinas e equipamentos \\
\hline Finalizar o desenvolvimento do produto/serviço \\
\hline Definir local de instalação da empresa \\
\hline Definir nome e marca \\
\hline Elaborar o contrato social para registro da empresa nos órgãos competentes \\
\hline SUBPROCESSO 4: Gerenciar os primeiros anos de vida \\
\hline Atividade empreendedora \\
\hline Realizar a primeira venda \\
\hline Efetuar a primeira ação de divulgação \\
\hline Contratar primeiros colaboradores \\
\hline Fazer controles financeiros \\
\hline Tomar decisões estratégicas \\
\hline
\end{tabular}

FONTE: Elaborado pelo autor

\subsection{Comportamento empreendedor}

O grupo de autores que tratou o empreendedorismo sob a ótica da psicologia ficou conhecido como comportamentalista, conforme já mencionado anteriormente neste estudo. Todavia, esse grupo também pode ser dividido. Um primeiro grupo é composto pelos autores que analisaram principalmente as características e motivações dos empreendedores, baseados principalmente nos estudos de McClelland (1961 e 1987).

O segundo grupo surgiu nos últimos anos, com uma nova linha de pesquisa sobre comportamento empreendedor, interessada em unir conhecimentos da área de empreendedorismo com conhecimentos da área de comportamento, especialmente de comportamento organizacional, duas áreas já estabelecidas na literatura de gestão. Esse grupo procura observar o comportamento do empreendedor como as ações manifestas por este durante a condução do processo empreendedor. Segundo Muller et al (2012), aumentou a quantidade de estudos cujo objetivo é descrever o comportamento empreendedor.

Bird (1989) foi pioneira nos novos estudos sobre comportamento empreendedor e na sua nova abordagem, menos ligada às características e motivações e mais voltada às teorias de comportamento organizacional. A autora considera esse comportamento como um tipo de comportamento organizacional. 
Recentemente, Dew et al (2008) analisaram a ligação entre a teoria do comportamento organizacional, em específico a teoria comportamental da firma (BTF - Behavioral theory of the firm) de Cyret e March (1963) e o empreendedorismo. Os autores entendiam que, segundo a teoria do comportamento organizacional, uma organização já estabelecida procura evitar a incerteza e gerenciar as expectativas de maneira racional. A organização também procura sempre optar pela alternativa que maximiza resultados futuros. Ao analisar o comportamento dos empreendedores, Dew et al (2008) acreditavam que eles preferiam soluções que satisfazem sua necessidade imediata (ao invés de soluções que maximizam resultados futuros) e que permitem que se beneficiem das incertezas.

Mueller et al (2012) também acreditavam que o comportamento do empreendedor que está no processo de criação de uma empresa é diferente do comportamento em organizações já estabelecidas. Portanto, é possível afirmar que existe uma nova e crescente linha de estudos sobre o comportamento empreendedor que têm como base a teoria do comportamento organizacional. Devido à evolução dessas pesquisas, atualmente já é possível identificar algumas diferenças entre o comportamento organizacional tradicional e o comportamento empreendedor.

A importância do tema como área de estudo do empreendedorismo é crescente, mas ainda não existe consenso em muitas de suas definições. Segundo Bird et al (2012), é importante estudalo, uma vez que ainda se entende pouco sobre o comportamento dos empreendedores e também se esse comportamento é distinguível do de outras pessoas. Ou seja, para identificar o comportamento dos empreendedores, é preciso entender como esse comportamento difere de outros tipos de comportamentos. Se levar em conta a teoria do comportamento organizacional, é preciso pensar como difere o comportamento empreendedor do comportamento de um indivíduo ou do conjunto de indivíduos em uma organização já estabelecida.

Bird e Schjoedt (2009, p.334) também "afirmaram que não existe ainda uma clareza sobre o comportamento empreendedor", assim como Gartner et al (2010), que procuraram definir o escopo e as fronteiras dos estudos de comportamento empreendedor para que este possa ser considerado um campo de estudos do empreendedorismo. Como ainda não existe consenso sobre o que é comportamento empreendedor, como defini-lo e suas fronteiras, o tema não 
consegue ganhar relevância para a área, uma vez que estudos com finalidades e definições dispersas tratam sobre o mesmo tema.

Em 2012, a revista acadêmica Entrepreneurship Theory and Practice, uma das mais importantes publicações acadêmicas sobre empreendedorismo, publicou uma edição especial dedicada a estudos sobre o comportamento empreendedor. Segundo Bird et al (2012, p. 889), que foram os responsáveis por essa edição da revista, o foco dos estudos nessa área são as pesquisas que analisam a "ação humana na criação, sobrevivência e primeiros estágios de crescimento de uma nova empresa, ou seja, os comportamentos durante a exploração de uma oportunidade". Mueller et al (2012) têm entendimento semelhante. Para eles, o foco desses estudos é descobrir o que os empreendedores realmente fazem. Para Gartner et al (2010), o foco dos estudos em comportamento empreendedor está em explorar como várias atividades realizadas por indivíduos emergem em organizações.

Para conhecer a literatura de comportamento empreendedor Bird et al (2012) analisaram os artigos publicados nas principais revistas acadêmicas mundiais de empreendedorismo e gestão. Essa análise resultou em 91 artigos publicados entre 2004 e 2010. O comportamento foi tratado como variável dependente, independente e de controle. A maioria dos estudos era cross-sectional, com alguns poucos longitudinais. Muitas medições usaram questionários auto-administrados de comportamentos atuais ou passados. Com isso é possível entender que a quantidade de artigos é crescente, mas ainda não existe um consenso sobre como o comportamento deve ser tratado.

Essa análise permitiu que Bird et al (2012, p.890) caracterizassem o comportamento empreendedor como "as ações concretas, teoricamente observáveis de indivíduos na fase de start-up ou nos primeiros estágios da criação de uma organização (normalmente 6 ou 7 anos)". Gartner et al (2010) acrescentam que o comportamento empreendedor ocorre por um período determinado de tempo (o que o classifica como um processo), e também entendem que deve ser individual e resultar em uma organização.

De maneira mais operacional, Bird et al (2012, p.890) definem comportamento como "ações que podem ser gravadas em áudio ou vídeo e podem ser obtidas por questionários autoadministrados". O comportamento pode ser dividido em eventos, tarefas ou processos e podem ter uma escala que vai de abstrato a específico. Comportamentos mais abstratos são 
difíceis de serem observados, mas podem ser acessados com questionários auto-administrados (BIRD et al, 2012). Ou seja, comportamento empreendedor pode ser caracterizado como as ações realizadas pelos empreendedores desde a ideia até a criação e manutenção da empresa nos primeiros anos e que podem ser observadas quando ele descrever como ocorreu esse processo.

Bird et al (2012) também afirmaram que os comportamentos são o resultado de características, conhecimentos, habilidades, cognição, motivação e emoção. Os autores concluíram suas análises afirmando que no futuro espera-se que os estudos tragam mais clareza ao que é o comportamento empreendedor e que seja possível analisar modelos situacionais. Essa afirmação de Bird et al (2012) está alinhada com o entendimento de comportamento empreendedor adotado por esta tese, na qual o comportamento será analisado conjuntamente com as características do empreendedor, e como influenciador do desempenho da empresa, que será observado nos indicadores de resultados alcançados pela mesma.

\subsubsection{Diferentes abordagens para o comportamento empreendedor}

$\mathrm{O}$ | comportamento empreendedor pode ter diferentes abordagens, conforme pode ser constatado pelos autores Endres e Woods (2006) e Fisher (2012). Os primeiros dois autores propuseram três diferentes abordagens teóricas para analisar o comportamento empreendedor. Estas abordagens, comumente chamadas de teorias foram: a teoria neoclássica, a teoria austríaca e a teoria comportamental. As duas primeiras teorias são voltadas à visão econômica do empreendedor e a teoria do comportamento, à visão psicológica. Esse tipo de divisão das teorias sobre comportamento empreendedor já foi citado anteriormente nesta tese.

Fisher (2012) propôs que as abordagens teóricas sobre o comportamento empreendedor poderiam ser divididas em bricolagem, effectuation e causation. Nesse caso todas as abordagens têm foco nas teorias comportamentais. As abordagens com foco causal, são aquelas de autores que propõem a ênfase em planejamento prévio para as ações dos empreendedores, enquanto que as com foco effectual procuram entender a forma de agir no dia a dia do empreendedor. A bricolagem propõe um modelo híbrido, mas ainda é uma teoria pouco desenvolvida e por isso não será observada em maiores detalhes nessa tese. 
Endres e Woods (2006) não analisaram trabalhos que tratassem especificamente de comportamento empreendedor, como fizeram Bird et al (2012) e Fillion (1997), e também não analisaram as teorias de comportamento organizacional. Os autores consideraram as teorias que relatavam uma sequência de comportamentos pelos quais o indivíduo descobria e explorava uma oportunidade de lucro. As análises de Endres e Woods (2006) tem foco no papel do empreendedorismo para a economia, enquanto que nesta tese o foco são as características e comportamentos do empreendedor ao agir.

Segundo Endres e Woods (2006), a abordagem neoclássica é baseada na criação da empresa em um contexto competitivo equilibrado. O empreendedor é visto como um recurso a mais, dentre os diversos que são necessários para a criação da empresa. O que diferencia o empreendedor dos demais recursos é que ele é um indivíduo que aceita o risco e por isso deve receber o lucro da empresa. Os autores neoclássicos entendem ainda que o empreendedor é o principal tomador de decisão da empresa e procura sempre otimizar o lucro derivado do risco que está correndo. Eles entendem que, diante da incerteza, a resposta do empreendedor será sempre sistemática, usando procedimentos de cálculos estatísticos para avaliar as oportunidades e as possíveis consequências de suas ações, e isso pressupõe também que ele tem todas as informações para tomar uma decisão. Essa forma de enxergar o empreendedor acredita que as oportunidades sempre terão o mesmo valor e estão disponíveis para serem exploradas por qualquer empreendedor.

Na prática, essa abordagem considera que todas as oportunidades e todos os empreendedores são iguais e que o mercado é estável, mas as imperfeições do mercado fazem com que, ao explorar a oportunidade, o empreendedor nunca tenha o retorno que havia planejado. Essa forma de analisar o empreendedor favorece uma análise geral de como a economia funciona, mas não responde às questões de como empreendedores agem de maneiras diferentes diante da mesma situação. Portanto, nessa tese não foi esse o enfoque de análise utilizado para avaliar o empreendedor.

Segundo Endres e Woods (2006), os autores da escola austríaca entendem que os empreendedores não são apenas indivíduos que estão mais dispostos que outros a correr riscos, mas são indivíduos que estão constantemente alertas às oportunidades. Isso significa que estão preparados para reconhecer oportunidades e para coordenar os recursos necessários para explora-las. Os autores dessa escola entendem que as oportunidades são latentes ou 
criadas por circunstâncias de mercado e que nem todas são descobertas ou exploradas instantaneamente. Diferentemente dos autores neoclássicos, esses autores acreditam que as oportunidades podem ser particulares para alguns empreendedores. Concordando com os neoclássicos, eles propõem que para explorar a oportunidade deve existir um processo, mas que as probabilidades de sucesso só são conhecidas quando esse processo tem início. A oportunidade só é assim considerada se for explorada. Os austríacos veem o empreendedor também como um indivíduo que procura otimizar o lucro em relação ao risco durante a exploração da oportunidade.

Essa escola procurava observar mais evidências empíricas do que a anterior, aproximando-se mais do empreendedor e suas ações do que do papel teórico do empreendedor em modelos econômicos. Ainda assim, a abordagem neoclássica não foi a utilizada nesta tese, uma vez que ela ainda analisa o empreendedor como um ser que tem todas as informações e consegue tomar a decisão ótima, o que não ocorre ao se observar os empreendedores em ação.

Segundo Endres e Woods (2006), os autores da escola comportamental consideram que o ambiente encontra-se em constante mudança e que os empreendedores não conseguem analisar todas as oportunidades possíveis de ação para tomar decisões ótimas. As oportunidades não estão prontas para serem exploradas, mas são percebidas e criadas pelo empreendedor em um processo cognitivo que não é otimizado, mas que envolve construções mentais que levam em conta a oportunidade e as aspirações pessoais. Elas não estão prontas sempre, podem ser criadas e são exploradas usando estratégias que vão moldando-as, de forma diferente se outras estratégias tivessem sido utilizadas.

A abordagem comportamental é a que mais se aproxima do que foi analisado do empreendedor nesta tese, com uma observação da maneira como ele realiza as atividades envolvidas em todo o processo empreendedor.

Analisando as três abordagens, é possível afirmar que a abordagem neoclássica se preocupa em analisar como o empreendedor ideal atuaria no contexto de criação de uma empresa. Já as abordagens austríaca e comportamental procuram observar empiricamente o empreendedor real. Em relação à descoberta da oportunidade, os austríacos acreditam que ela é existente e que o empreendedor é o indivíduo que está alerta e por isso a descobre, já a abordagem comportamental acredita que o empreendedor pode gerar e moldar as oportunidades ao seu 
estilo. Para explorar as oportunidades os austríacos acreditam que o empreendedor busca maximizar o retorno, focado nos fins, e não nos meios. Já os comportamentalistas veem o empreendedor como alguém que toma decisões constantemente baseado no contexto em que está presente. Para os comportamentalistas, o empreendedor está mais focado em minimizar o risco do que maximizar o retorno.

Outro autor que identificou diferentes abordagens para o comportamento empreendedor foi Fisher (2012), que propôs a bricolagem, a effectuation e a causation. Sua forma de dividir as abordagens diverge da proposta por Endres e Woods (2006). Enquanto esses autores observaram o comportamento empreendedor mais pela ótica de teorias econômicas, Fisher (2012) observou o comportamento deste agente sob a ótica das teorias do comportamento organizacional. De qualquer forma, é possível associar a causation à abordagem neoclássica, e, principalmente à escola austríaca e a effectuation e a bricolagem à escola comportamental.

Nesta tese serão abordados os tipos de comportamento causal e effectual. Essa opção se justifica pelo fato de serem dois tipos antagônicos que representam o extremo do planejamento a priori e da ação realizada sem planejamento algum. Entende-se que nenhum empreendedor seguirá em algum dos extremos durante todo o processo empreendedor, mas espera-se identificar se a prevalência de algum desses tipos de comportamento pode influenciar o desempenho da empresa criada.

\subsubsection{Causation}

Segundo Fisher (2012), este é o modelo mais tradicional de empreendedorismo, derivado das teorias de economia, em que o indivíduo procura uma área onde a demanda por um produto é maior que a oferta, descobre uma oportunidade e posteriormente avalia se deve ou não explora-la. Quando decide explora-la, ele busca e reúne os recursos para isso e, então, gera lucro.

Essa forma de se comportar já é descrita por autores anteriores, estivessem eles interessados em descrever o comportamento empreendedor ou não. Nos estudos de Endres e Woods (2006) é possível observar esse tipo de comportamento especialmente na descrição feita pelos economistas da escola austríaca. 
Sarasvathy (2001b) convencionou chamar esse comportamento tradicional do empreendedor de causation. Os empreendedores que se comportam dessa maneira realizam suas atividades com um objetivo previamente definido, de forma que consigam ao máximo controlar o que pode ocorrer no futuro e otimizar os recursos que têm disponíveis. Esses indivíduos procuram oportunidades em mercados já existentes e sua lógica é que sempre é preciso buscar informações para tomar uma decisão.

Este é o modelo de comportamento empreendedor mais tradicional descrito pela literatura. $\mathrm{O}$ plano de negócios é a ferramenta mais utilizada pelos empreendedores que pretendem se comportar dessa maneira. Ele é útil para que os empreendedores possam "[...]planejar suas ações e delinear as estratégias da empresa a ser criada [...]” (DORNELAS, 2008 p.79). É um documento escrito que descreve o estado atual e projeta o futuro de uma organização empresarial (HONIG; KARLSSON, 2004, p.29).

O plano de negócios deve mostrar as pessoas que estarão envolvidas com o negócio, a oportunidade que será explorada e o contexto em que o novo negócio estará envolvido. Segundo Schilit (1987), o plano de negócios serve para avaliar o estágio atual e futuro de uma organização e seu ambiente, delinear os objetivos de curto e de longo prazos baseado na avaliação realizada e desenvolver diretrizes de ações apropriadas para atingir este objetivo.

É possível entender que, como afirmam Bianchi et al (1998), as pequenas empresas sofrem ainda mais do que as grandes com a imprevisibilidade do futuro e a complexidade (ligada a fatores internos ou externos), de modo que fica ainda mais difícil elaborar um planejamento. Mas o plano de negócios, mesmo que não consiga prever com exatidão o que irá ocorrer no futuro, pode ser um direcionamento para a empresa e, dessa forma, auxiliar a definir o risco em que o empreendimento está incorrendo. A diminuição do risco é também de interesse do empreendedor, que, diferentemente do que algumas pessoas afirmam, também quer evitar o risco (SAHLMAN, 1997).

Segundo Bianchi et al (1998), o crescimento das pequenas empresas depende de quanto o empreendedor consegue discernir entre as decisões do presente (objetivos de curto prazo) e do futuro (objetivos de longo prazo). O conflito entre os objetivos de longo prazo e de curto prazo é um dos maiores enfrentados pelos empreendedores. Enquanto alguns sentem-se mais 
confortáveis em seguir atrás dos objetivos de longo prazo, outros tomam como foco as ações do presente, sem levar em conta suas possíveis consequências.

O plano de negócios é mais utilizado pelos empreendedores que tendem a agir de forma a priorizar as ações que lhe permitam atingir os seus objetivos de longo prazo previamente definidos. Segundo Rhonda (2003), o plano de negócios é a melhor ferramenta para um empreendedor atingir seus objetivos de longo prazo, permitindo que ele tome decisões mais acertadas, entenda as finanças da empresa, busque informações da indústria e mercados e antecipe e evite problemas.

\subsubsection{Effectuation}

O termo effectuation, embora já existisse em raros estudos da área de economia, foi introduzido às pesquisas de empreendedorismo por Saras D. Sarasvathy durante seu doutorado na Carnegie Mellon University. Seus estudos sobre o tema resultaram na tese na qual Sarasvathy (1998, p. 1) definiu effectuation como

\footnotetext{
"O processo pelo qual o empreendedor (individual ou time de empreendedores) no momento préempresa identifica, define e, frequentemente, cria um mercado para sua ideia, e também cria uma base de recursos e uma rede de stakeholders"
}

A afirmação de que o empreendedor cria um mercado deve ser observada com atenção. A autora não pretende com isso afirmar que todos os empreendedores criam inovações radicais que estimulam uma nova necessidade nos consumidores e consequentemente levam à criação de um novo mercado. Sua afirmação pretende demonstrar, que mesmo em mercados já consolidados, uma nova ideia pode conquistar parte desses consumidores, que atualmente são atendidos pelas empresas já existentes.

Também é preciso entender que a autora definiu como momento pré-empresa as ações que o empreendedor realiza no momento que antecede à formalização do seu negócio, ou seja ela pretende estudar o comportamento do empreendedor desde que ele teve uma ideia, até chegar à consolidação do negócio. 
A pesquisa empírica realizada por Sarasvathy (1998) foi dividida em duas partes totalmente independentes. Ambas as partes usaram protocolos de pensar em voz alta, um método amplamente usado nas ciências cognitivas para estudar tomada de decisões de especialistas. Os protocolos foram analisados utilizando-se análise de clusters e análise de conteúdo.

A primeira parte da pesquisa comparou empreendedores com banqueiros em relação à sua percepção e gestão de vários tipos de riscos. Para formular esse problema, Sarasvathy (1998) buscou autores anteriores que analisaram a relação de empreendedores com o risco. Além dos autores tradicionais, a autora analisou estudos que traziam uma visão diferenciada da relação entre o empreendedor e o risco. Esses estudos demonstravam que o empreendedor não é necessariamente um indivíduo que está mais propenso a correr riscos do que os outros indivíduos.

Para testar empiricamente sua hipótese, Sarasvathy (1998) apresentou cinco problemas (dois envolvendo somente risco financeiro, dois envolvendo risco para a vida humana e saúde e o último envolvendo o risco de um desastre natural) para quatro empreendedores e quatro banqueiros. $\mathrm{O}$ mesmo problema foi apresentado a todos os participantes, que foram orientados a pensar em voz alta a forma como o resolveriam.

As conclusões dessa parte da pesquisa mostraram que os empreendedores aceitam o risco como dado (determinam um nível de risco aceitável) e, após isso, consideram alternativas para aumentar o retorno; eles também enquadram o espaço de seus problemas com valores pessoais e assumem grande responsabilidade pessoal pelos resultados. Já os banqueiros focam em metas de retorno, tentando controlar o risco e evitando situações em que existe alto risco de responsabilidade pessoal.

A segunda parte do estudo de Sarasvathy (1998) foi mais completa e investigou o processo decisório de 30 empreendedores que criaram empresas que, em março de 1997 (época do estudo), tinham capital aberto e vendas anuais entre $\$ 200$ milhões e $\$ 6,5$ bilhões. O objetivo da pesquisa era descobrir semelhanças e diferenças no processo de decisão dos empreendedores.

Para isso, foi utilizado um exemplo fictício de uma ideia de empresa e definido um conjunto de dez decisões empreendedoras que precisam ser solucionadas ao criar uma nova empresa 
para desenvolver, produzir e comercializar um produto imaginário. Essas decisões foram baseadas em uma extensa pesquisa em literatura técnica e sobre histórias de startups, e também foi ratificada com empreendedores da região que não participaram posteriormente da amostra. As análises e resultados das primeiras duas das dez decisões foram apresentados na tese. Essas duas eram as decisões relacionadas especialmente a mercados.

A decisão 1 solicitou que os participantes respondessem cinco questões sobre como identificar um mercado potencial para a empresa. A decisão 2 ofereceu dados de pesquisa de mercado primária e secundária e requereu que os participantes tomassem três decisões de marketing.

Para responder à sua questão principal, Sarasvathy (1998) desenvolveu a seguinte hipótese: "Empreendedores experientes em uma situação de pré-firma exibem nenhuma preferência particular para qualquer uma das três possíveis crenças sobre previsibilidade do futuro.”.

Uma vez que a hipótese tem relação com a previsibilidade do futuro, é preciso descrever como Sarasvathy (1998) tratou teoricamente essa questão. Baseada em estudiosos anteriores, a autora criou o quadro reproduzido a seguir, em que trata da previsibilidade e apresenta o termo effectuation, que é a base de toda a sua teoria.

Quadro 4 - Taxonomia de fenômenos futuros

\begin{tabular}{|l|l|l|}
\hline & Baixa Previsibilidade & Alta previsibilidade \\
\hline Apenas ação humana & $\begin{array}{l}\text { Incerteza/Desequilíbrio } \\
\text { Regras desconhecidas } \\
\text { Effectuation }\end{array}$ & $\begin{array}{l}\text { Risco/Equilíbrio } \\
\text { Regras conhecidas } \\
\text { Teoria dos jogos }\end{array}$ \\
\hline $\begin{array}{l}\text { Ação humana e da } \\
\text { natureza }\end{array}$ & $\begin{array}{l}\text { Incerteza } \\
\text { Distribuição } \\
\text { desconhecida } \\
\text { Probabilidade subjetiva }\end{array}$ & $\begin{array}{l}\text { Risco } \\
\text { Distribuição } \\
\text { conhecida } \\
\text { Probabilidade }\end{array}$ \\
\hline $\begin{array}{l}\text { Apenas ação da } \\
\text { natureza }\end{array}$ & Ex: Terremotos & $\begin{array}{l}\text { Ex: Padrões do clima } \\
\text { de curto prazo }\end{array}$ \\
\hline
\end{tabular}

FONTE: Adaptado de SARASVATHY (1998)

É possível entender que effectuation refere-se a um fenômeno futuro, influenciado exclusivamente pela ação humana, ou seja, acredita que o futuro pode ser criado pela ação humana consensual. Com isso, entende-se que, ao optar por agir segundo a effectuation, as 
pessoas preferem ter ações com o objetivo de criar um futuro com baixa previsibilidade e seguindo regras desconhecidas do que gastar tempo e energia tentando prever o futuro desconhecido.

A análise dos resultados obtidos na pesquisa empírica demonstrou estatisticamente que, ao lidar com os problemas de decisão, os empreendedores expressam comportamentos do tipo effectual com mais frequência, com isso a autora rejeitou a hipótese nula.

A análise dos resultados obtidos para a decisão 2 mostrou que $63 \%$ das afirmações feitas por $74 \%$ dos participantes são afirmações sobre a forma de prever o futuro do mercado usando a effectuation, o que Sarasvathy (1998) entende que é razoável para concluir que a maioria dos empreendedores experientes busca o comportamento effectual na maior parte do tempo.

Os resultados da parte 2 da pesquisa mostraram que os participantes acreditavam que estavam lidando com uma incerteza que não poderia ser prevista, mas poderia ser influenciada e modelada pelas suas próprias ações. Para lidar com esse tipo de situação as respostas dos participantes mostraram que eles usam um conjunto de princípios heurísticos que a autora chamou de effectuation.

Effectuation pode ser considerado o oposto de causation. Causation assume um efeito como dado e seleciona dentre as possíveis causas como atingir o efeito desejado. Effectuation é o oposto, começa com uma causa ou conjunto de causas e iterativamente seleciona de um conjunto grande e open-ended de possíveis efeitos, usando tanto métodos de tentativa e erro quanto mecanismos de feedback de todos os tipos.

O resultado da pesquisa empírica permitiu a Sarasvathy (1998) propor uma forma alternativa de tomada de decisões de explorar um mercado por parte dos empreendedores. Enquanto a maneira clássica de definir um mercado para atuação da empresa segue as etapas listadas a seguir:

1) Definição do mercado: Identificar um universo de todos os consumidores de determinado produto.

2) Segmentação: Dividir esse universo (mercado) em segmentos baseados em critérios como demográfico, nível de renda, e outros. 
3) Definição do alvo: Coleta e análise das informações (fazendo pesquisas de mercado) para decidir o segmento alvo ótimo.

4) Definição do posicionamento: Desenvolvimento de um plano de marketing para atingir os consumidores do segmento alvo ótimo.

Sarasvathy (1998) propôs um processo diferente, que criou as bases da effectuation e está descrito a seguir:

Perda acessível: Encontrar uma maneira criativa de levar a ideia ao mercado com um pequeno investimento de tempo, dinheiro ou pesquisa de mercado - usando métodos tais como tentar vender para a primeira pessoa acessível ou tornando o primeiro consumidor acessível um parceiro estratégico antes mesmo de terminar o desenvolvimento completo do produto, dentre outros. Em outras palavras, desenvolver expectativas de retornos positivos não é uma condição prévia para levar uma ideia ao mercado;

Definição do consumidor: Generalizando o perfil do primeiro consumidor em um segmento de consumidores alvo, baseado tanto no processo de tentativa e erro iterativo e no feedback detalhado de cada iteração;

Expandindo as parcerias: Criando parcerias estratégicas, especialmente com consumidores, por meio da expansão das redes que tornam-se segmentos de mercado. A busca por parceiros estratégicos é contínua e versátil, fazendo uso de eventos de contingencia ao longo do ciclo de vida da pré-empresa;

Definição de mercado: O empreendedor na pré-empresa começa com somente um consumidor e generaliza o conceito do primeiro consumidor dentro dos limites de um ambiente de mercado adicionando segmentos baseados em eventos contingentes e eventualmente definindo a posição da empresa no ambiente de mercado. Essa definição do ambiente de mercado é determinada em termos de o que eles são e o que eles não são selecionando alguns consumidores e desprezando outros. Similarmente, o posicionamento da empresa nos ambientes de mercado selecionados é especificad tanto para o que ela é quanto para o que ela não é. 
A tese de Sarasvathy (1998) foi a base inicial para a criação da linha de pesquisa sobre effectuation em empreendedorismo. Seu trabalho é passível de críticas, uma vez que as análises feitas não conseguem garantir a negação das hipóteses propostas - muitas vezes a autora fez considerações que ainda não foram suficientemente testadas posteriormente pela comunidade de pesquisadores de empreendedorismo. Além disso, a amostra de 30 empreendedores ou de 4 empreendedores e 4 banqueiros utilizados, precisa ter seus resultados replicados em outras pesquisas em grandes amostras.

A definição da pré-empresa e da empresa também pode ser motivo de críticas. Acreditar que uma pré-empresa só se torna uma empresa quando torna-se de capital aberto exclui do universo milhares de empresas de capital fechado, que mereceriam ser consideradas. Todavia, a tese apresenta uma nova visão sobre o comportamento dos empreendedores que foi muito aceita por outros pesquisadores e deu início a uma nova linha de pesquisa.

$\mathrm{O}$ artigo que trata a tese com maior profundidade foi publicado por Sarasvathy na Academy of Management Review em 2001. Nesse artigo, Sarasvathy (2001a) faz uma forte discussão teórica para explicar a teoria da effectuation e sua contraposição à causation. Sarasvathy (2001a) explica a effectuation fazendo sua contraposição à causation, mas a autora explica que ambas podem ocorrer simultaneamente e que uma não é melhor que a outra. A contraposição serve para facilitar a explicação da effectuation, mas, na prática, nem sempre as ações e decisões são guiadas por um extremo ou outro.

A autora cita situações em que as diferentes formas de agir podem prevalecer. Segundo Sarasvathy (2001a), a causation é melhor para explorar conhecimentos, enquanto a effectuation é melhor quando existem contingências. A causation também é melhor quando é possível analisar e entender um processo futuro. Dessa forma, se o tomador de decisão acreditar que é possível medir ou prever razoavelmente o futuro, ele tende a buscar informações e analisa-las. Enquanto isso, a effectuation é ideal para lidar com o futuro incerto, em uma situação em que pode ser analisado somente o presente. Nesse caso o tomador de decisão deve usar a experimentação.

Sarasvathy e Kotha (2001) também trabalharam os conceitos da effectuation, especialmente sua contraposição com a causation. As autoras usaram um caso real de uma empresa de 
internet para mostrar como, na prática, os princípios propostos na teoria da effectuation se sobrepuseram aos propostos pelas teorias mais tradicionais.

Usando o que iniciou em sua tese e focando o aspecto comportamental do empreendedor, Sarasvathy (2001b) procurou mostrar que a forma de pensar effectual é o que faz com que algumas pessoas sejam empreendedoras, e com isso sejam diferentes de gestores ou estrategistas. Uma nova proposição nesse artigo é que a autora afirma que a lógica effectual é mais útil quando se pretende explorar um novo produto em um novo mercado, espaço este onde as técnicas de marketing tradicionais não costumam ser muito efetivas.

Sendo assim, é possível concluir que o effectuation é uma forma de se comportar do empreendedor de maneira mais intuitiva. Também é possível identificar que o comportamento do empreendedor não é necessariamente linear, podendo variar ao longo do processo e podendo também variar de acordo com o ambiente em que a empresa está sendo criada.

Nesta tese o comportamento do empreendedor será medido por meio do seu comportamento declarado durante a realização das tarefas que compõem o processo empreendedor. Esse comportamento pode variar de um extremo em que o indivíduo privilegia o benefício imediato em detrimento do benefício futuro a outro extremo em que o indivíduo privilegia as recompensas de longo prazo, mesmo que para isso precise abrir mão de benefícios imediatos.

\subsection{Desempenho da empresa criada}

Os estudos de empreendedorismo que pretendem medir o resultado econômico gerado pelo processo empreendedor utilizam em sua maior parte medidas de desempenho da empresa.

Medir o desempenho da empresa é muito difícil e apresenta um desafio para os pesquisadores (MURPHY et al, 1996; CHANDLER; HANKS, 1993). Embora a literatura esteja repleta de estudos que apresentam possíveis indicadores de desempenho de uma empresa, ainda não existe consenso a respeito de qual variável, ou qual conjunto de variáveis, melhor representa o desempenho da empresa que nasceu (BRUSH; VANDERWERF, 1992; MURPHY et al, 1996). Também existem dificuldades para obter os dados (MURPHY et al, 1996) - pois como as pequenas empresas não são obrigadas a divulgar informações, muitas informações podem 
não estar disponíveis (CHANDLER; HANKS, 1993) - e para comparar empresas muito diferentes (MURPHY et al, 1996), especialmente em indústrias diferentes que podem afetar o desempenho financeiro (CHANDLER; HANKS, 1993).

Os estudos que analisam o desempenho de uma nova empresa não realizam análises sobre as métricas que irão ser utilizadas para esta finalidade São escassos, de fato, os estudos que mensuram desempenho de empresas novas, simplesmente definem algumas métricas mais comuns, baseadas em estudos anteriores que mediram o desempenho de novas empresas ou utilizam métricas que são comuns em estudos de medidas de desempenho, mesmo que essas métricas tenham como foco medir desempenho de grandes empresas já estabelecidas. Os estudos que se destacam por ter analisado as formas de medir o desempenho da empresa pequena ou nascente de maneira mais aprofundada são os estudos de Brush e Vanderwerf, (1992), Murphy et al (1996) e Chandler e Hanks (1993).

Com a intenção de identificar qual o melhor indicador para medir o desempenho de uma nova empresa, Brush e Vanderwerf (1992) fizeram uma revisão da literatura de trinta e quatro artigos publicados entre 1987 e 1988 sobre empreendedorismo que mediram algum aspecto do desempenho. Os autores estavam preocupados não só com os indicadores utilizados, mas também com o método de coleta de dados e as fontes de informações utilizadas. Eles identificaram que o principal método para obter dados era a survey, utilizando questionários auto-administrados e que a principal fonte de informações eram os gestores, executivos, fundadores ou proprietários.

Especificamente sobre as métricas de desempenho da empresa, Brush e Vanderwerf, (1992) encontraram trinta e cindo métricas diferentes, sendo que as mais populares foram alterações na receita das vendas, alterações no número de empregados, lucratividade (retorno das vendas, retorno do investimento e lucro líquido), e continuidade/descontinuidade do negócio. A maioria dos estudos analisados usaram múltiplas medidas que em sua maioria eram objetivas, com o uso de escalas, embora existissem também questões abertas e de múltipla escolha. Poucos estudos utilizavam medidas subjetivas.

Assim como Brush e Vanderwerf (1992), Murphy et al (1996) também fizeram uma extensa revisão da literatura procurando encontrar os melhores indicadores para definir o desempenho empreendedor. Os autores analisaram cinquenta e um artigos de empreendedorismo 
publicados entre 1987 e 1993 e que usavam o desempenho como variável dependente. Posteriormente os autores aplicaram as medidas mais citadas para analisar o desempenho de uma amostra de pequenas empresas.

Murphy et al (1996) identificaram que a maioria das métricas utilizadas provém das teorias das organizações ou da estratégia. As proposições da gestão estratégica podem ser divididas ainda em três correntes teóricas. A primeira que analisa uma empresa essencialmente pelo seu desempenho financeiro, a segunda que também leva em conta a qualidade do produto e a participação de mercado (que de alguma forma também acabam por afetar o desempenho da empresa no longo prazo), e a terceira que considera múltiplas dimensões.

As medidas de desempenho mais utilizadas, segundo Murphy et al (1996), podem ser divididas em três grupos: eficiência, crescimento e lucro. Para medir a eficiência são utilizados o retorno sobre o investimento (ROI), o retorno sobre os ativos (ROA) ou o retorno sobre o patrimônio (ROE). Para medir o crescimento utiliza-se o crescimento na quantidade de empregados e ou de vendas e para medir o lucro utilizam-se retorno das vendas, margem de lucro líquida e margem de lucro bruta. Os autores sugerem ainda que sejam utilizadas sempre várias medidas de desempenho, visto que a relação entre uma variável independente e o desempenho pode até ser invertida quando se usa outra métrica para medir o desempenho.

Chandler e Hanks (1993) analisaram as três estratégias mais utilizadas em pesquisas de desempenho de novas empresas quando apenas dados de questionários auto-administrados estão disponíveis e apresentaram uma comparação. As estratégias analisadas foram:

1) Usar categorias amplas para medir o desempenho,

2) Usar medidas subjetivas de satisfação do proprietário sobre o desempenho,

3) Usar medidas subjetivas de desempenho em relação aos concorrentes.

Os estudos de Chandler e Hanks (1993) identificaram que a estratégia mais adequada é utilizar duas categorias amplas, o crescimento e o volume de negócios, tendo essa estratégia apresentado resultados melhores que as outras duas. - Essas duas categorias foram escolhidas por terem sido as mais citadas pelos empreendedores em pesquisas que utilizaram questionários auto-administrados. Além disso, as medidas tradicionais podem não ser apropriadas. As taxas de crescimento podem ser muito variadas e gerar muitos outliers. 
Medidas convencionais (ROE, ROI e ROA) também são problemáticas. Os ativos podem ser muito pequenos, então uma empresa que tem retorno pequeno, mas ativos muito pequenos, pode parecer muito melhor que outra mais sólida, mas com mais ativos.

Chandler e Hanks (1993 p.404) afirmam que

\footnotetext{
"Quando se pretende usar questionários auto-administrados como medida do desempenho da empresa, crescimento e volume de negócios são as dimensões de desempenho mais familiares e mais referenciadas pelos fundadores".
}

Para operacionalizar a categoria crescimento os autores utilizaram três itens.

1) Crescimento percebido da participação de mercado

2) Mudanças no fluxo de caixa

3) Crescimento de vendas

Já para a categoria volume de negócios Chandler e Hanks (1993) utilizaram:

1) Renda gerada para o empreendedor incluindo o seu salário

2) Vendas

3) Patrimônio Líquido

Os resultados obtidos por Chandler e Hanks (1993) mostraram que é adequado usar as dimensões amplas crescimento e volume de negócios, pois elas são consideradas relevantes pelos empreendedores e mostraram consistência interna superior à satisfação com o desempenho da própria empresa e validade superior à satisfação com o desempenho em relação aos competidores. Os autores inclusive consideram que pode não ser adequado utilizar a satisfação com o desempenho da empresa.

Esses foram os três autores que analisaram as formas de medir o desempenho da empresa por meio de uma análise mais aprofundada Os demais estudos que utilizam o termo desempenho da empresa têm foco em outras questões da empresa ou do empreendedor e utilizam o desempenho como variável dependente para identificar outros aspectos da empesa ou do empreendedor que podem afetá-lo. 
Miner (1997), em seu estudo procurava relacionar os tipos psicológicos dos empreendedores e o seu sucesso. O autor usou métricas de desempenho empreendedor para medir o que caracterizou como sucesso. As métricas utilizadas foram a variação anual nas vendas (em valores monetários), na quantidade de empregados e na lucratividade.

Man et al (2008) usaram o desempenho empreendedor como variável dependente em seu estudo para analisar as competências empreendedoras. Os autores utilizaram três grupos de indicadores: eficiência do investimento, crescimento da empresa e desempenho relativo à concorrência. A eficiência do investimento é representada pelo retorno do capital investido na empresa, pela margem de lucro bruta, pelo lucro líquido das operações, pelo índice de lucro sobre vendas e pelo retorno sobre o investimento.

Assim como Man et al (2008), Wiklund e Shepherd (2005) também acreditam que é importante usar o crescimento da empresa ou de alguns de seus resultados financeiros para medir o desempenho. Esses autores afirmam que usar os valores contábeis apenas, sem considerar a variação de um ano para outro, pode ter validade pequena devido à grande variedade de setores de atuação e portes das empresas.

Wiklund e Shepherd (2005) afirmam, entretanto, que uma empresa pode trocar crescimento no longo prazo por lucro no curto prazo. Por isso o desempenho deve ser medido de modo multidimensional e deve integrar diferentes dimensões. Os autores sugerem uma combinação de medidas de desempenho financeiro e de crescimento. Para desempenho financeiro sugerem medidas coletadas por meio de questionários auto-administrados de margem bruta e lucratividade e fluxo de caixa comparado aos concorrentes. Foi solicitado aos respondentes que estimassem o lucro e as vendas do último ano, e a margem bruta, como o indicador do lucro bruto para as vendas. Também foi solicitado que estimassem o lucro e o fluxo de caixa comparado com os competidores em uma escala de cinco pontos, que ia de muito pior a muito melhor. Para estimar o crescimento da empresa os autores utilizaram os indicadores de crescimento das vendas e da quantidade de empregados.

Witt (2004) propôs diferentes formas de medir se uma empresa tinha ou não sucesso. A primeira forma seria considerar que a empresa ter sido criada já pode ser caracterizado como a conclusão adequada do processo empreendedor. Outra forma seria por meio da avaliação subjetiva do fundador. Uma terceira forma proposta seria a sobrevivência e permanência da 
empresa no mercado. Nesse caso, o autor propõe que é possível identificar a data de fundação da empresa e, então, verificar quais empresas continuam existindo por mais tempo.

Witt (2004) também propôs o uso de um conjunto de medidas objetivas, analisando sempre o crescimento dessas medidas e o número absoluto, pois empresas muito novas podem ter taxa de crescimento bem maior do que empresas antigas mais estabelecidas. Para relativizar as medidas o autor sugere usar indicadores financeiros dos últimos três anos e também dividir a quantidade de empregados pelo número de anos de existência da empresa. $\mathrm{O}$ autor sugere que devem ser analisados a receita de vendas, a quantidade de empregados, ou o balanço da empresa. Para obter os dados, sugerem-se entrevistas ou questionários pessoais feitos com o empreendedor.

Witt (2004) propõe uma terceira opção, que é utilizar indicadores comumente utilizados por grandes empresas, tais como lucro e retorno sobre o investimento, mas o autor alerta que utilizar esses indicadores pode gerar o problema de empresas nascentes precisarem sacrificar lucro e fluxo de caixa para aumentar o crescimento. $\mathrm{O}$ autor também destaca a dificuldade de obter essas informações de empresas que não são obrigadas a divulga-las.

Frese et al (2000), para medir o sucesso econômico de uma empresa usaram as variáveis crescimento de vendas, de lucro, de investimento e renda pessoal obtida pelo empreendedor desde o início da empresa. Ao invés de solicitar dados objetivos no seu questionário para medir a renda pessoal e a quantidade de empregados, os autores utilizavam gráficos que mostravam o desempenho ao longo dos anos e pediam que os empreendedores escolhessem o que mais se adequava à sua situação. Essas escolhas foram transformadas posteriormente em uma escala de 5 pontos. Para medir mudanças em vendas, lucro e investimento, foi solicitado que o próprio empreendedor desenhasse o gráfico que representa a evolução desde o início da empresa até o momento presente.

Sandberg e Hofer (1987) também utilizaram o desempenho da nova empresa como variável dependente. Como o objetivo desses autores era estudar somente empresas ambiciosas, que buscavam principalmente o crescimento econômico, eles utilizaram o retorno sobre o patrimônio (ROE) como o principal critério de desempenho. Diferentemente de outros autores que usam múltiplos critérios, Sandberg e Hofer (1987) criaram cinco grupos que iam de muito 
sucesso, com ROE bastante alto, até muito insucesso, que era a falência da empresa. Os entrevistados deveriam selecionar em qual dos cinco grupos sua empresa melhor se inseria.

Wiklund e Shepherd (2003) usaram o desempenho como variável dependente do estudo que queria analisar a importância da base de conhecimentos da empresa e da orientação empreendedora. O desempenho da empresa foi analisado usando múltiplas variáveis. Diferentes dos estudos citados anteriormente em que o respondente deveria considerar apenas o desempenho de sua empresa, neste caso foi solicitado que o respondente comparasse o desenvolvimento de sua empresa nos últimos três anos em relação aos dois mais importantes concorrentes em dez diferentes dimensões de desempenho: crescimento de vendas, crescimento de receita, crescimento na quantidade de empregados, margem de lucro líquida, inovação em produto/serviço, inovação no processo, adoção de novas tecnologias, qualidade do produto/serviço, variedade do produto/serviço e satisfação do consumidor. A análise deveria ser feita utilizando uma escala de cinco pontos que ia de muito pior a muito melhor. A forma de obter os dados proposta por Wiklund e Shepherd é considerada uma forma subjetiva de se perguntar dados objetivos, sendo assim, o autor evita o problema de ter respostas muito diferentes devido a empresas que possam estar em realidades muito diferentes, mas ele acrescenta o erro que pode existir da subjetividade de análise do empreendedor em relação à sua empresa e aos concorrentes.

Hmieleski e Corbett (2008), em sua pesquisa, usaram uma variável única para medir o desempenho da empresa, que era o crescimento das vendas. Chattopadhyay e Ghosh (2002) usaram para medir o sucesso do empreendedor o lucro anual da empresa e o turnover anual. $\mathrm{O}$ lucro foi considerado o aumento do lucro anual dividido pelo número de anos que a empresa existe. - O turnover é entendido pelo incremento do turnover dividido pelo número de anos que a empresa existe. Cooper e Artz (1995 p.447) usou como variável de controle “a quantidade de dinheiro retirada da empresa pelo empreendedor nos últimos 12 meses, incluindo salários, dividendos e outros".

As várias métricas para medir o desempenho receberam críticas. Cooper e Artz (1995) criticam a utilização de métricas que utilizam o fluxo de caixa gerado para medir o desempenho de empresas iniciantes. Esses autores acreditam que, no período inicial da empresa, o fluxo de caixa gerado pode ser baixo, inclusive afetando a remuneração dos empreendedores, mas nesse período muitas empresas necessitam reinvestir o fluxo de caixa 
para que possam ter melhor desempenho no longo prazo. Embora tenham feito críticas, essa foi a métrica utilizada por esses autores.

Walker e Brown (2004 p.578) também criticaram as métricas mais tradicionais, como a quantidade de empregados e o lucro, turnover ou retorno sobre investimento. Eles entendem que essas métricas pressupõem que todas as empresas querem ou precisam crescer.

Ao indagar os empreendedores sobre sua satisfação como empreendedor, Chandler e Hanks (1993) identificaram que alguns empreendedores preocupavam-se mais em manter o controle da empresa do que em crescer ou ganhar dinheiro, portanto o desempenho da empresa pode estar relacionado à expectativa que o empreendedor tem e ao que deseja para o futuro da empresa, que nem sempre é crescer. Witt (2004) encontrou resultados semelhantes de empreendedores que não desejavam crescer para não perder o controle sobre a empresa e a qualidade dos produtos e dos funcionários.

Após analisar toda a literatura existente sobre o desempenho das empresas nascentes optou-se por utilizar na pesquisa desta tese, cinco métricas, a saber: quantidade de vendas, aumento da base de clientes, receita, lucro líquido e quantidade de empregados. - Além disso, existirá uma questão para saber se a empresa ainda existe ou já foi descontinuada ou vendida. A questão será apresentada para o empreendedor em um questionário auto-administrado, que deverá indicar o crescimento de cada uma das métricas acima citadas na sua empresa observando o horizonte dos últimos três anos. 


\section{METODOLOGIA DE PESQUISA}

\subsection{Método de pesquisa utilizado}

Esta pesquisa foi realizada tendo por base as orientações do método survey, ou levantamento. Segundo Hair et al (2005 p.157) "Survey é um procedimento para coleta de dados primários a partir de indivíduos.”, o que atendeu aos objetivos, uma vez que pretendia-se obter dados de indivíduos que são empreendedores. Ainda segundo Hair et al (2005 p.157), “... as surveys são usadas quando o projeto de pesquisa envolve a coleta de informações de uma grande amostra de indivíduos.", o que também atendeu ao objetivo da presente pesquisa.

A survey utilizou questionários auto-administrados, ou seja, não havia um pesquisador presente no momento da resposta. Segundo Hair et al (2005), esse tipo de questionário está sujeito à baixa taxa de resposta e deve-se cuidar para que o conteúdo e o formato sejam atraentes o suficiente para motivar o respondente. Buscando diminuir esses problemas, foi realizado um pré-teste do questionário com 10 empreendedores que faziam parte da população-alvo, com 5 especialistas em empreendedorismo e com 2 especialistas em métodos quantitativos.

Outro ponto importante de ser observado na aplicação da survey que foi apresentado por Hair et al (2005) refere-se à necessidade de conhecimento sobre o assunto por parte dos respondentes. Neste caso, todos os respondentes possuíam conhecimento prévio sobre o tema da pesquisa, pois foram entrevistados somente aqueles que já vivenciaram a experiência de iniciar uma empresa e já buscaram alguma vez conhecimento sobre plano de negócios e empreendedorismo.

Foi utilizado um questionário eletrônico, cuja cópia encontra-se no apêndice 1, hospedado em um servidor independente ao qual somente os respondentes tiveram acesso. $\mathrm{O}$ acesso ao banco de dados com as respostas dos questionários foi exclusivo do pesquisador.

A pesquisa foi transversal, uma vez que os dados foram coletados na extração de apenas uma amostra da população e as informações dessa amostra foram obtidas uma única vez no tempo (MALHOTRA, 2001). 
É possível afirmar que a pesquisa é descritiva, uma vez que procura identificar se existe associação entre as variáveis do comportamento empreendedor e o desempenho da empresa criada. Segundo Cooper e Schindler (2011) estudos descritivos procuram descobrir associações entre as diferentes variáveis.

A pesquisa pode ser dividida em duas fases. A primeira teve como objetivo descrever as características que são mais presentes no perfil dos empreendedores pesquisados, descrever o comportamento empreendedor que prevalece em cada atividade e sub-processo do processo empreendedor e descrever tipos de comportamento empreendedor.

A segunda e principal fase da pesquisa teve como objetivo verificar a existência de relação entre o perfil empreendedor, o comportamento empreendedor durante a condução do processo de criação da empresa e o desempenho da empresa após sua criação.

Dessa forma, esta pesquisa é descritiva com a obtenção dos dados de maneira transversal por meio da utilização de uma survey eletrônica com questionários auto-administrados.

\subsection{Definição do universo e da amostra}

Antes de definir o universo e a amostra, é importante que seja definida qual será a unidade de amostragem do estudo. Nesta pesquisa a unidade de amostragem foram os indivíduos que em algum momento de sua vida estiveram envolvidos na atividade de criação de uma nova empresa, ou seja, empreendedores.

Espera-se que os resultados da pesquisa sejam relevantes para os empreendedores brasileiros. De acordo com Greco et al (2011 p. 15), existiam no Brasil em 2011 aproximadamente "27 milhões de adultos entre 18 e 64 anos que estão envolvidos na criação ou já administraram um negócio próprio", ou seja, que são ou já foram empreendedores no Brasil.

No entanto, diante da impossibilidade de realizar uma pesquisa que representasse todos os empreendedores brasileiros, optou-se neste estudo por realizá-la com indivíduos cadastrados em um portal de negócios (www.planodenegocios.com.br) na internet que oferecia 
informação sobre empreendedorismo e plano de negócios. O portal existe desde o ano 2000, com 15 anos de atuação e acesso totalmente gratuito. Neste período se tornou uma das principais referências em língua portuguesa (especialmente para brasileiros) para empreendedores que procuram informações sobre empreendedorismo e ferramentas para o desenvolvimento de planos de negócios. Nesse período formou uma base de dados que conta com mais de 130.000 usuários cadastrados, dos quais aproximadamente 30\% estão ou já estiveram envolvidos na criação de um novo negócio. Sendo assim, a população do presente estudo são os empreendedores cadastrados no referido website. Segundo Hair et al (2005 p.239) “A população alvo é o grupo completo de objetos ou elementos relevantes para o projeto de pesquisa.".

Uma vez que não seria viável coletar dados de todos os indivíduos dessa população, buscouse definir uma amostra para ser realizada a pesquisa. Hair et al (2005 p.237) entendem que "uma amostra é um subconjunto relativamente pequeno da população". O processo de seleção dos indivíduos que fariam parte da amostra pode ser probabilístico ou não-probabilístico (HAIR et al, 2005 e SAMPIERI et al, 2006). Para Sampieri et al (2006 p. 254) "Escolher uma amostra probabilística ou não probabilística depende dos objetivos do estudo, tipo de pesquisa e da contribuição que se pensa fazer com ela.”. Na presente pesquisa, levando-se em conta os objetivos e as limitações, optou-se por utilizar a amostra não-probabilística. Segundo Hair et al (2005), essa forma de amostragem usa métodos subjetivos para selecionar os elementos da amostra, o que não permite que os resultados sejam generalizados para a população-alvo, mas "Isso não significa que amostras não probabilísticas não devem ser utilizadas. De fato, em algumas situações, elas podem ser a alternativa preferível” (HAIR et al 2005 p. 246).

Definido o método que seria utilizado para fazer a amostragem, buscou-se entender como selecionar os elementos que fariam parte da amostra. Para Sampieri et al (2006 p.254), "Nas amostras não-probabilísticas, a escolha dos elementos não depende da probabilidade, mas sim das causas relacionadas com as características da pesquisa ou de quem faz a amostra.". Para a seleção da amostra foi usado o critério de conveniência. Para Hair et al (2005 p. 247) esse critério “[...] envolve a seleção de elementos de amostra que estejam mais disponíveis para tomar parte no estudo e que podem oferecer as informações necessárias.”.

Nesta pesquisa foi efetuado um primeiro corte entre todos os indivíduos da base de dados com a finalidade de utilizar apenas aqueles que correspondiam ao público-alvo de interesse para 
responder ao questionário. O corte visou a excluir os indivíduos que nunca participaram do processo de criação de uma empresa, ou seja, não podem ser considerados empreendedores para os objetivos desta pesquisa. Para tanto, existia uma afirmação na introdução do questionário orientando para que ele fosse respondido somente por quem já possuiu ou é atualmente proprietário de uma empresa, como pode ser visto no apêndice 1.

Como benefício da amostragem por conveniência, foi possível realizar um estudo com um grande número de respondentes, porém não será possível generalizar os resultados deste estudo para a população nem principalmente para todos os empreendedores brasileiros. Segundo Hair et al (2005) os indivíduos selecionados por essa forma podem ser diferentes da população alvo, assim não é possível generalizar.

A pesquisa foi enviada para todos os usuários cadastrados no referido portal. Foi enviada via e-mail com a solicitação para que fosse respondido um questionário armazenado em um servidor independente. Foram enviados dois e-mails para toda a base de usuários, o que resultou em 467 respondentes, dos quais 10 foram excluídos após análise da existência de outlier multivariado, resultando em 457 casos válidos. Os outliers eram compostos de indivíduos que indicaram sempre o mesmo valor da escala em todas as questões de determinada seção da pesquisa, o que demonstrava que não responderam com veracidade às questões.

A amostra com 457 casos é adequada para a realização das análises. Segundo Barclay et al (1995) apud Hair et al (2013) a amostra mínima para realizar a PLS deve ter dez vezes o maior número de indicadores formativos utilizados para medir um único constructo, sendo assim é possível afirmar que a amostra mínima para o presente estudo seria de 80 casos, número bastante inferior aos 457 casos apresentados.

Esse tamanho de amostra respeita também a amostra mínima proposta por Cohen (1992) apud Hair et al (2013), segundo o qual, quando existem 8 variáveis para o mesmo constructo, como o presente estudo, para se obter, com nível de significância de $1 \%$ e $\mathrm{R}^{2}$ mínimo de 0,10 , a amostra mínima deve ter 238 casos, menos que os 457 casos apresentados. É possível afirmar, portanto, que o tamanho da amostra utilizada atende ao tamanho mínimo sugerido pelos diferentes autores, dos menos aos mais criteriosos. 


\subsection{Instrumento de coleta de dados}

$\mathrm{O}$ instrumento de pesquisa foi dividido em quatro grandes partes. A primeira delas continha questões cujo objetivo era identificar o comportamento do empreendedor. A segunda parte das questões pretendia identificar as características empreendedoras, a terceira buscava identificar o desempenho da empresa e a quarta continha questões sobre características pessoais do respondente. Todas as partes serão descritas em detalhes a seguir.

\subsubsection{Comportamento do empreendedor}

O instrumento criado para mensurar o comportamento empreendedor durante a condução do processo de criação da empresa utilizou escala numérica de dez pontos. Segundo Hair et al (2005, p. 187), “[...]esse tipo de escala pode ser usado para avaliar o nível com que se concorda ou discorda de algo". Ainda segundo Hair et al (2005) essas medidas podem ser classificadas e analisadas como métricas.

$\mathrm{O}$ instrumento de pesquisa solicitou inicialmente que o respondente lembrasse-se do momento de criação de sua empresa e de como ele conduziu cada uma das etapas desse processo.

O questionário sobre o comportamento empreendedor foi construído com vinte e seis sentenças afirmativas, de modo que houvesse pelo menos uma sentença afirmativa sobre cada uma das atividades realizadas pelos empreendedores durante o processo de criação da empresa. Algumas das sentenças afirmam que o empreendedor realizou a atividade priorizando o planejamento e seus objetivos no futuro, e outras sentenças afirmam que ele realizou a atividade priorizando os benefícios imediatos. Essa associação entre a atividade e a sentença pode ser observada no apêndice 2 .

As vinte e seis afirmações estavam divididas entre os quatro sub-processos que fazem parte do processo empreendedor. O comportamento do empreendedor em cada sub-processo será também mensurado utilizando-se escalas de itens múltiplos, ou seja, a resposta a cada uma das afirmações será somada ao final criando um escore único para medir o comportamento do empreendedor naquele subprocesso. Segundo Hair et al (2005, p. 195), esse tipo de escala consiste em "uma série de afirmações individuais estritamente relacionadas cujas respostas são combinadas em um escore composto para medir um conceito." 
Como o instrumento de coleta de dados foi aplicado pela primeira vez, alguns cuidados foram tomados para garantir que tenha validade e confiabilidade. Segundo Hair et al (2005), o pesquisador deve "... garantir que as variáveis selecionadas para representar e mensurar o conceito o fazem de maneira precisa e coerente".

Segundo Hair et al (2005) validade é o ponto até onde um construto mede o que deve medir, e existem três tipos: validade de conteúdo, de constructo e de critério. Para garantir a validade de conteúdo, Hair et al (2005) sugere consultar uma pequena amostra de respondentes típicos e/ou especialistas.

Dessa forma o presente questionário foi avaliado por 5 especialistas em empreendedorismo e por 2 especialistas em métodos quantitativos. Também foi realizado um pré-teste em que o pesquisador acompanhou a resposta com 10 empreendedores para analisar o tempo que demoraram para responder todo o questionário e se tinham sugestões. Hair et al (2005) sugere que todo questionário deve passar por um pré-teste.

Tanto a avaliação dos especialistas quanto o pré-teste resultaram em sugestões de melhoria, especialmente para a redação das questões, que foram então aprimoradas pelo pesquisador antes de aplicar o questionário à amostra final.

\subsubsection{Características pessoais do empreendedor}

O questionário para identificação das características dos empreendedores contará com as questões propostas por McClelland (1965; 1987; RAVEN, 2001). Esse questionário é utilizado nos projetos da United Nations Conference on Trade and Development (UNCTAD), como pode ser visto no apêndice 3. Ele propõe cinquenta e cinco afirmações sobre atitudes e ações do empreendedor para serem respondidas em uma escala que vai de 1 (discordo totalmente) a 5 (concordo totalmente). Considera-se que o instrumento está consolidado na literatura, tendo sido aplicado em pesquisas acadêmicas (VENTURI, 2003; MATIAS, 2010) e também no Projeto Empretec - capacitação de potenciais empreendedores realizado em vinte e sete países, o que lhe assegura fidedignidade e validação empírica. 


\subsubsection{Desempenho atual da empresa}

Existia uma seção do questionário para identificar o desempenho atual da empresa criada. $\mathrm{O}$ mesmo questionário tinha questões objetivas para que o empreendedor descrevesse a variação ocorrida nos principais indicadores de desempenho de uma empresa propostos pela literatura analisada.

\subsubsection{Outras questões}

Além do instrumento para coletar as informações relativas às características e comportamento do empreendedor e do desempenho da empresa criada, o questionário contava com outras questões. Existia uma questão para identificar a idade, o grau de escolaridade e o gênero do respondente e quantas vezes ele já esteve envolvido na criação de uma nova empresa e o seu conhecimento prévio do setor de atuação. Também havia uma questão sobre o grau de inovação da empresa que o empreendedor criou e sobre o seu setor de atuação. Essas questões podem levantar indícios para novas propostas de pesquisas futuras.

\subsection{Procedimentos de coleta de dados}

O procedimento para coleta de dados foi realizado por meio de questionário eletrônico que foi disponibilizado em um servidor independente contendo todas as questões. Esse questionário completo encontra-se no Apêndice 1.

Foi enviado um e-mail para todos os cento e trinta mil usuários cadastrados no portal de negócios, solicitando que aqueles que fossem empreendedores (já tivessem participado do processo de criação de uma empresa em algum momento de sua vida) respondessem ao questionário para auxiliar em uma pesquisa acadêmica.

O questionário ficou aberto para respostas durante sessenta dias, o que resultou em um total de 467 indivíduos que responderam ao questionário. Todos esses deverão receber o resultado da pesquisa após sua conclusão, conforme prometido previamente.

\subsection{Técnicas utilizadas no tratamento dos dados}


Foram utilizadas técnicas estatísticas univariadas e multivariadas para tratamento dos dados desta pesquisa. A análise foi realizada especialmente com o auxílio dos softwares SPSS® (Statistical Package for the Social Sciences) e SmartPLS 3.0® e Microsoft Excel®.

As primeiras análises na amostra final foram realizadas para caracterizá-la. Foram analisadas as distribuições de frequência das questões relativas à idade dos respondentes, ao grau de escolaridade, ao setor de atuação, e ao grau de inovação da empresa. A partir dessas informações, foram realizadas análises descritivas de frequência, média e desvio-padrão.

Dentre as técnicas multivariadas de análise, primeiramente foi realizada uma análise de agrupamentos ou clusters, técnica que foi utilizada para definir os padrões de comportamento dos empreendedores. Segundo Hair et al (1998), essa análise pretende agrupar objetos segundo suas características, formando grupos homogêneos. Os grupos devem ter homogeneidade interna e heterogeneidade externa. Pretendeu-se criar grupos de empreendedores com comportamento semelhante, podendo até serem criadas tipologias de comportamento do empreendedor no processo empreendedor.

A segunda técnica utilizada foi a modelagem de equações estruturais (structural equations modeling -SEM) baseada no método PLS (Partial Least Squares). De acordo com Hair El at (2014) essa técnica é utilizada para desenvolver teorias, especialmente em pesquisas exploratórias. Segundo Klem (1995), essa técnica pode ser vista como uma extensão à regressão múltipla, que pode ser utilizada quando o pesquisador está interessado em prever mais de uma variável dependente. Na presente pesquisa pretendeu-se estimar se existe relação entre o comportamento empreendedor, seu perfil (características) e o desempenho da empresa.

Para Maruyama (1998) a modelagem de equações estruturais deve partir de um modelo conceitual que demonstre as relações entre um conjunto de variáveis. Dessa forma, Farias e Santos (2000) acreditam que a teoria oferece o ponto central dessa técnica.

O primeiro modelo conceitual que foi utilizado nesta pesquisa é o proposto por McClelland (1987). Esse modelo prevê que as 10 características empreendedoras (variáveis) analisadas podem ser agrupadas em 3 fatores. 
O segundo modelo conceitual foi criado pelo autor e visa a identificar o comportamento do empreendedor na condução do processo de criação de uma empresa. Esse processo foi dividido em 26 atividades principais que foram consideradas como as variáveis. O terceiro modelo conceitual também será criado pelo autor para identificar o desempenho da empresa.

A modelagem por equações estruturais identificou as relações entre os fatores do modelo de características empreendedoras de McClelland, com o comportamento empreendedor e principalmente relações entre os comportamentos e o desempenho da empresa.

\subsection{Modelo conceitual da pesquisa}

A partir da fundamentação teórica e procurando responder aos objetivos desta pesquisa foi desenvolvido um modelo conceitual que é apresentado na Ilustração 11. Este modelo apresenta o perfil do empreendedor, tanto em relação às características empreendedoras propostas por McClelland (1987) quanto em relação a outras características pessoais do empreendedor em seu lado esquerdo. Esse perfil deve influenciar a forma de agir do empreendedor durante o processo de criação da empresa, neste modelo detalhado em suas quatro etapas. Durante o processo empreendedor, foi observado o comportamento explicitado pelo empreendedor. Esse comportamento pode variar entre dois extremos, o causal e o effectual. Tanto o perfil, quanto o comportamento do empreendedor influenciam o desempenho da empresa criada, que foi medido por meio de cinco indicadores descritos no extremo direito do modelo apresentado na Ilustração 11. 


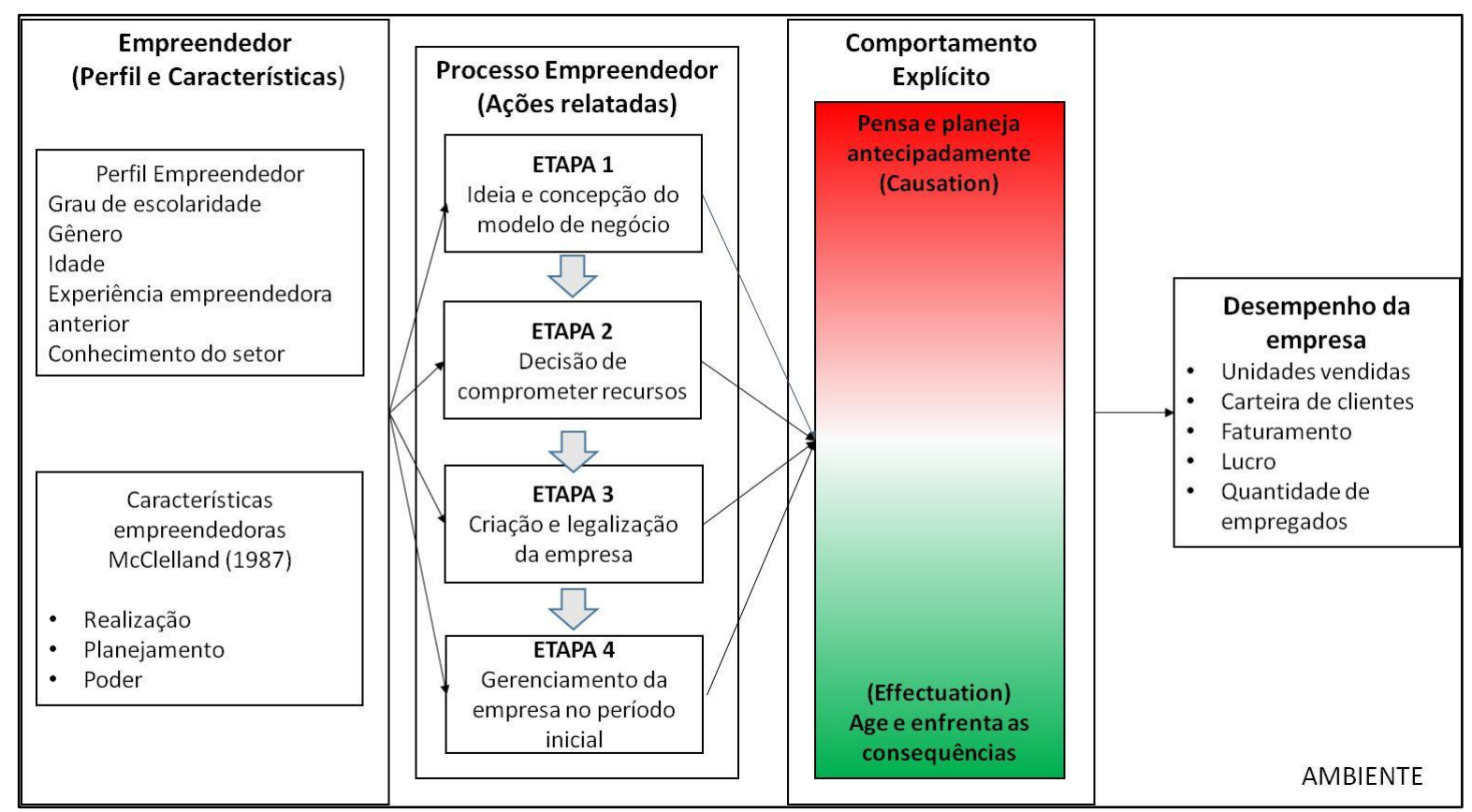

Ilustração 12 - Modelo conceitual da pesquisa

FONTE: Elaborado pelo autor 


\section{APRESENTAÇÃO E ANÁLISE DOS DADOS DA PESQUISA}

\subsection{Apresentação e Análise dos dados}

O primeiro passo para realização das análises foi a identificação e posterior exclusão dos outliers existentes na amostra. Primeiro verificou-se a existência de outliers univariados, quando não foi detectada a necessidade de exclusão de nenhum caso. Em seguida, foi analisada a presença de outliers multivariados, com a utilização do software SPSS, por meio do cálculo da Distância de Mahalanobis, e esse teste apontou para a exclusão de 10 casos, que possuíam z-score acima de 2,5, o que representa significância menor que 0,001. De acordo com Hair et al (1998), devido à sua natureza esse teste deve ser usado com uma medida bem conservadora, ou seja, apenas valores de significância inferiores a 0,001 devem ser excluídos. Dessa forma, a amostra utilizada para as análises foi de 457 casos e não de 467 casos como inicialmente definida.

\subsubsection{Caracterização da Amostra}

A amostra utilizada para este estudo é composta de 457 casos, todos eles indivíduos que em algum momento se cadastraram no banco de dados de um portal de negócios na internet, e que se disponibilizaram a responder voluntariamente à pesquisa, que estava hospedada em um servidor independente. Todos os indivíduos da amostra declararam já ter participado de pelo menos um processo empreendedor em algum momento da sua vida.

A amostra é composta predominantemente por homens, com 75,71\% dos indivíduos assim caracterizados, como pode ser observado na Tabela 01. Essa relação é bastante diferente da apresentada por Greco et al (2013), que aponta que 52,2\% dos empreendedores brasileiros são mulheres.

Tabela 1 - Gênero dos participantes

\begin{tabular}{|l|r|c|}
\hline Gênero & \multicolumn{1}{|l|}{ Quantidade } & $\%$ \\
\hline Masculino & 346 & $76 \%$ \\
\hline Feminino & 111 & $24 \%$ \\
\hline
\end{tabular}


Em relação ao grau de escolaridade, identifica-se que $48 \%$ dos indivíduos declararam possuir nível de pós-graduação e 30\%, ensino superior completo. Essa informação pode ser observada na Tabela 02. Devido ao alto grau de escolaridade dos indivíduos da amostra, suspeita-se de que ela é composta de pessoas que teriam oportunidades em outras ocupações, devido ao seu alto grau de instrução, mas que optaram pelo caminho empreendedor.

O grau de escolaridade dos indivíduos da presente amostra também é bastante diferente daquele apresentado pelo Greco et al (2013), que aponta que 50,9\% dos empreendedores brasileiros não têm o segundo grau completo, $35,1 \%$ completaram apenas o segundo grau e apenas $14 \%$ têm mais do que o segundo grau completo.

Tabela 2 - Grau de escolaridade

\begin{tabular}{|l|r|r|}
\hline Grau de escolaridade & Quantidade & \multicolumn{1}{|c|}{$\%$} \\
\hline Ensino Médio incompleto & 12 & $3 \%$ \\
\hline Ensino Médio completo & 15 & $3 \%$ \\
\hline Ensino Superior incompleto & 32 & $16 \%$ \\
\hline Ensino Superior completo & 139 & $30 \%$ \\
\hline Pós-Graduação & 219 & $48 \%$ \\
\hline
\end{tabular}

Com as duas caracterizações da amostra apresentadas até aqui, é possível afirmar que tanto o gênero quanto o grau de escolaridade dos indivíduos pesquisados não correspondem ao padrão médio do empreendedor brasileiro, identificado por Greco et al (2013). Dessa forma, uma das limitações do presente estudo é que o mesmo não pode ser generalizado para todos os empreendedores brasileiros, visto que essas diferenças na amostragem fazem com que a mesma não seja representativa da população de empreendedores do Brasil.

Outra característica analisada dos empreendedores foi o conhecimento prévio que possuíam do negócio em que exerceram o processo empreendedor. Metade (50\%) dos empreendedores declararam ter conhecimento prévio do setor, mas não consideravam que o dominavam, e apenas $10 \%$ dos empreendedores se aventuraram por um setor no qual não tinham nenhum conhecimento, como pode ser observado na Tabela 03. 
Tabela 3 - Conhecimento prévio do setor de atuação

\begin{tabular}{|l|r|c|}
\hline Conhecimento setor atuação & Quantidade & $\%$ \\
\hline Conhecia muito o setor & 91 & $20 \%$ \\
\hline Conhecia o setor, mas não dominava & 228 & $50 \%$ \\
\hline Conhecia um pouco do setor & 92 & $20 \%$ \\
\hline Não tinha conhecimento do setor & 46 & $10 \%$ \\
\hline
\end{tabular}

A maioria dos empreendedores da amostra passou recentemente pelo processo empreendedor, sendo que $42 \%$ deles ainda estão atualmente envolvidos no processo e $23 \%$ estiveram em um período entre 2 e 5 anos anteriores ao momento em que responderam à pesquisa, como pode ser observado na Tabela 04.

Tabela 4 - Quando conduziu o processo empreendedor

\begin{tabular}{|l|r|c|}
\hline Quando conduziu o processo empreendedor & Quantidade & $\%$ \\
\hline Está atualmente conduzindo o processo & 193 & $42 \%$ \\
\hline Conduziu o processo há mais de 2 anos & 107 & $23 \%$ \\
\hline Conduziu o processo há mais de 5 anos & 81 & $18 \%$ \\
\hline Conduziu o processo há mais de 10 anos & 76 & $17 \%$ \\
\hline
\end{tabular}

Também foi analisada a quantidade de vezes em que os indivíduos participaram de um processo empreendedor, visto que existem autores que acreditam que a experiência em participar deste processo pode ser positiva para o seu desempenho. Identificou-se que $69 \%$ dos respondentes já estiveram envolvidos em mais do que um processo empreendedor, ou seja, têm experiência prévia como empreendedor, como pode ser observado na Tabela 05.

Tabela 5 - Experiência empreendedora prévia

\begin{tabular}{|l|r|c|}
\hline Já foi responsável por conduzir quantos processos? & Quantidade & $\%$ \\
\hline 1 & 147 & $31 \%$ \\
\hline 2 & 148 & $32 \%$ \\
\hline 3 & 76 & $16 \%$ \\
\hline 4 ou mais & 96 & $21 \%$ \\
\hline
\end{tabular}

Nas informações relativas às empresas resultantes dos processos empreendedores, observa-se na Tabela 06 que os setores que predominaram nas respostas foram o setor de comércio tradicional e o de serviços, contrariando a expectativa de que, por ser uma pesquisa feita pela internet, com usuários cadastrados em um portal de negócios na internet, existisse grande quantidade de respondentes de empresas de comércio eletrônico. 
Como essa questão só permitia uma resposta é possível que algumas empresas se enquadrassem em mais de um setor de atuação, no comércio tradicional e no eletrônico, por exemplo, mas tenham respondido apenas à informação do setor predominante de atuação.

Tabela 6 - Setor de atuação da empresa

\begin{tabular}{|l|r|r|}
\hline Setor de atuação da empresa & Quantidade & \% \\
\hline Comércio tradicional & 84 & $18 \%$ \\
\hline Comércio eletrônico & 20 & $4 \%$ \\
\hline Indústria & 42 & $9 \%$ \\
\hline Serviços & 258 & $56 \%$ \\
\hline Agricultura & 12 & $3 \%$ \\
\hline Outros & 41 & $9 \%$ \\
\hline
\end{tabular}

Os indivíduos foram ainda indagados a respeito do grau de inovação de sua empresa, visto que existem indícios de que empresas mais inovadoras podem ter desempenho superior às demais. A maioria dos empreendedores (47\%) afirmou que as empresas eram inovadoras, em menor ou maior grau, ou seja, haviam criado algum novo produto ou serviço nos últimos anos, como pode ser observado na Tabela 07.

Tabela 7 - Grau de inovação da empresa

\begin{tabular}{|l|r|c|}
\hline A empresa é inovadora? & Quantidade & $\%$ \\
\hline Muito inovadora & 47 & $10 \%$ \\
\hline Inovadora & 171 & $37 \%$ \\
\hline Normal & 168 & $37 \%$ \\
\hline Pouco inovadora & 51 & $11 \%$ \\
\hline Nada inovadora & 20 & $4 \%$ \\
\hline
\end{tabular}

Com isso é possível afirmar que o respondente padrão desta pesquisa é homem, com pósgraduação e conhecimento prévio sobre o setor de atuação, embora sem domínio completo do mesmo. Ele está atualmente conduzindo o processo empreendedor, mas já esteve envolvido nesse processo mais de uma vez. A empresa atua no setor de serviços e é considerada inovadora, na ótica do seu empreendedor. 


\subsubsection{Análise do Perfil Empreendedor}

O perfil dos empreendedores foi coletado utilizando o instrumento proposto por McClelland (1987), que aponta o nível da presença de 10 características empreendedoras. Ainda seguindo os procedimentos propostos por McClelland (1987), essas características são posteriormente agrupadas em 3 grupos.

O perfil predominante nos empreendedores foi analisado com foco nos grupos de características, e não nas características individuais. Essa análise foi realizada de duas formas. - A primeira forma ocorreu com a análise do conjunto de características predominante no empreendedor, ou seja, não importando o grau de presença de cada característica, mas sim a que teve maior presença no perfil do empreendedor. Quando dois ou os três conjuntos de características estavam presentes no perfil do empreendedor no mesmo grau, esse tipo de perfil também foi considerado. Essa análise pode ser observada na Tabela 08.

Tabela 8 - Perfil do empreendedor

\begin{tabular}{|l|r|c|}
\hline Perfil predominante & Quantidade & \% \\
\hline Realização & 98 & $21 \%$ \\
\hline Planejamento & 206 & $44 \%$ \\
\hline Poder & 64 & $14 \%$ \\
\hline Realização e Planejamento & 60 & $13 \%$ \\
\hline Realização e Poder & 13 & $3 \%$ \\
\hline Planejamento e Poder & 13 & $3 \%$ \\
\hline Realização, Planejamento e Poder & 13 & $3 \%$ \\
\hline
\end{tabular}

De acordo com a análise da Tabela 08, é possível afirmar que o conjunto de características que mais se destaca no perfil dos empreendedores da amostra é o planejamento, que foi a característica principal de $44 \%$ dos empreendedores, além de ser uma característica predominante junto com outras, em 19\% dos entrevistados.

A segunda análise sobre o perfil dos empreendedores pesquisados foi realizada por meio da média da presença de cada um dos três grupos de característica no perfil dos elementos da amostra. É possível observar na Tabela 09 que o planejamento também se destaca nesta análise, mostrando média superior aos demais grupos de características. 
Tabela 9 - Perfil Empreendedor

\begin{tabular}{|l|r|r|r|}
\hline & \multicolumn{1}{|c|}{ Realização } & Planejamento & Poder \\
\hline Mediana & 19 & 19 & 18 \\
\hline Desvio Padrão & 2,165 & 2,496 & 2,291 \\
\hline Média & 18,47 & 18,92 & 17,84 \\
\hline Coeficiente de Variação & 0,117 & 0,132 & 0,128 \\
\hline
\end{tabular}

Com essas duas análises é possível responder a um dos objetivos da presente pesquisa, que busca descobrir qual a característica de perfil que aparece com maior frequência nos empreendedores da amostra pesquisada. É possível afirmar que a característica predominante é o planejamento.

Para garantir que existe diferença significativa entre os três grupos, foi realizado um teste não paramétrico, denominado Teste de Friedman, utilizando-se o software SPSS, cujos resultados são apresentados na Tabela 10.

\section{Tabela 10 - Resultado do Teste de Friedman}

\begin{tabular}{|l|r|}
\hline \multicolumn{2}{|c|}{ Test Statistics $^{\text {a }}$} \\
\hline N & 457 \\
Qui-quadrado & 114,394 \\
Df & 2 \\
Significância Assintótica &, 000 \\
\hline
\end{tabular}

a. Friedman Test

O teste de Friedman demonstra que existe diferença estatística significativa entre os três grupos devido ao resultado apresentado de Qui-quadrado de 114,394 e p=0,000.

Também foi realizado o teste de Wilcoxon, para testar se existe diferença entre os grupos de perfil dois a dois, utilizando-se o software SPSS. Os resultados deste teste são apresentados na Tabela 11. Com os valores de $\mathrm{Z}$ apresentados, muito superiores a 1,96, é possível afirmar que analisados dois a dois os grupos são estatisticamente diferentes. 
Tabela 11 - Resultado do teste de Wilcoxon

\begin{tabular}{|l|r|r|r|}
\hline & \multicolumn{2}{|c|}{ Test Statistics $^{\mathbf{a}}$} \\
& $\begin{array}{c}\text { Planejamento }- \\
\text { Realização }\end{array}$ & $\begin{array}{c}\text { Poder - } \\
\text { Realização }\end{array}$ & $\begin{array}{c}\text { Poder - } \\
\text { Planejamento }\end{array}$ \\
\hline Z & $-4,848$ & $-7,175$ & $-9,851$ \\
Sig. Assint. (2 caudas) &, 000 &, 000 &, 000 \\
\hline
\end{tabular}

a. Wilcoxon Signed Ranks Test

A realização desses dois testes supracitados permite concluir que todos os três conjuntos de características empreendedoras analisados são estatisticamente diferentes. Com isso, é possível afirmar que o conjunto de características de planejamento é predominante no perfil dos empreendedores da amostra, seguido pela realização e pelo poder, respectivamente.

Não é objetivo dessa pesquisa explicar o motivo dessa característica ter prevalecido no perfil dos empreendedores. A amostra da pesquisa ter sido extraída de um site com foco em plano de negócios pode ser uma dessas motivações. O perfil da amostra, composto de empreendedores com elevado grau de instrução, com experiência empreendedora prévia e proprietários de empresas inovadoras também pode ser uma das explicações. Pesquisas futuras poderão focar este objetivo e responder quais perfil de empreendedores têm a prevalência de características de planejamento.

\subsubsection{Análise do Comportamento Empreendedor}

Com o objetivo de analisar o comportamento (causal ou effectual) que prevalece em cada uma das atividades do processo empreendedor, analisou-se primeiramente as médias das respostas dos 457 casos pesquisados. Essas respostas são apresentadas na Tabela 12. Para realização da análise foi importante identificar que, quanto menor o valor, mais planejada foi a realização da atividade e, quanto maior o valor, menor foi o planejamento realizado. A descrição das atividades pode ser observada no Apêndice 2.

Tabela 12 - Atividades do Processo Empreendedor

\begin{tabular}{|c|c|c|c|c|c|}
\hline \multirow{2}{*}{} & & & & \multicolumn{2}{|c|}{$\begin{array}{c}\text { Intervalo de } \\
\text { Confiança }\end{array}$} \\
\cline { 4 - 6 } Atividade & Média & $\begin{array}{c}\text { Desvio } \\
\text { Padrão }\end{array}$ & Erro padrão & Mínimo & Máximo \\
\hline 1 & 5,97 & 2,93 & 0,14 & 5,83 & 6,11 \\
\hline 2 & 3,80 & 2,55 & 0,12 & 3,68 & 3,92 \\
\hline 3 & 7,10 & 2,41 & 0,11 & 6,99 & 7,21 \\
\hline
\end{tabular}




\begin{tabular}{|l|l|l|l|l|l|}
4 & 2,64 & 2,84 & 0,13 & 2,51 & 2,77 \\
\hline 5 & 3,00 & 2,84 & 0,13 & 2,87 & 3,13 \\
\hline 6 & 3,21 & 2,88 & 0,14 & 3,07 & 3,35 \\
\hline 7 & 4,82 & 3,56 & 0,17 & 4,65 & 4,99 \\
\hline 8 & 3,05 & 2,99 & 0,14 & 2,89 & 3,19 \\
\hline 9 & 4,22 & 3,48 & 0,16 & 4,06 & 4,38 \\
\hline 10 & 5,85 & 2,82 & 0,13 & 5,72 & 5,98 \\
\hline 11 & 3,87 & 3,00 & 0,14 & 3,73 & 4,01 \\
\hline 12 & 6,26 & 3,15 & 0,15 & 6,11 & 6,41 \\
\hline 13 & 4,74 & 3,42 & 0,16 & 4,58 & 4,90 \\
\hline 14 & 3,53 & 3,33 & 0,16 & 3,37 & 3,49 \\
\hline 15 & 4,04 & 3,55 & 0,17 & 3,87 & 4,21 \\
\hline 16 & 5,12 & 3,87 & 0,18 & 4,94 & 5,30 \\
\hline 17 & 8,18 & 2,22 & 0,10 & 8,08 & 8,28 \\
\hline 18 & 5,90 & 3,23 & 0,15 & 5,75 & 6,05 \\
\hline 19 & 3,28 & 3,20 & 0,15 & 3,13 & 3,43 \\
\hline 20 & 2,49 & 2,93 & 0,14 & 2,35 & 2,63 \\
\hline 21 & 2,96 & 3,00 & 0,14 & 2,82 & 3,10 \\
\hline 22 & 2,82 & 2,86 & 0,13 & 2,69 & 2,95 \\
\hline 23 & 7,54 & 2,74 & 0,13 & 7,41 & 7,67 \\
\hline 24 & 5,68 & 3,40 & 0,16 & 5,52 & 5,84 \\
\hline 25 & 2,07 & 2,52 & 0,12 & 1,95 & 2,19 \\
\hline 26 & 7,90 & 2,15 & 0,10 & 7,80 & 8,00 \\
\hline & & & & & \\
\hline
\end{tabular}

É possível identificar que as atividades que são realizadas com mais ênfase em planejamento prévio são as atividades $2,4,5,6,7,8,9,11,13,14,15,19,20,21,22,25$, enquanto as outras atividades priorizam a execução. Ou seja, dezesseis atividades são realizadas de modo predominantemente causal e dez atividades são realizadas de modo predominantemente effectual.

A predominância de atividades realizadas com foco no planejamento prévio, em detrimento de atividades realizadas com foco no benefício imediato, se opõe a Sarasvathy (1998), que afirma que a maioria dos empreendedores age de modo effectual na maior parte de suas atividades, e também contradiz Dew et al (2008), para quem os empreendedores priorizam ações imediatistas. Isso pode ser explicado por algumas características da presente amostra, que a tornam diferente da grande maioria dos empreendedores e também das amostras utilizadas pelos autores citados. A cultura americana, onde a pesquisa dos autores citados foi realizada é diferente da cultura brasileira, onde esta pesquisa foi realizada, o que pode ser outra explicação para os resultados diferentes. 
Também é possível afirmar que a atividade que foi realizada com menor planejamento prévio foi a atividade 17 e a que teve mais planejamento prévio foi a 25 . Na Tabela 13, para permitir uma análise mais aprimorada estão agrupadas as cinco atividades que caracterizam-se por ser realizadas com mais ênfase causal e effectual. A seleção dessas atividades foi feita de acordo com os valores das médias que mais se aproximavam dos extremos (menor valor demonstrava mais ênfase no comportamento do tipo causal e maior valor demonstrava mais ênfase no comportamento do tipo effectual).

Tabela 13 - Atividades com mais ênfase em comportamento causal e effectual

\begin{tabular}{|c|c|}
\hline \multicolumn{2}{|r|}{ Causal } \\
\hline 25 & $\begin{array}{l}\text { Acompanhava rotineiramente as finanças da empresa para ter certeza de que tudo seguia como eu } \\
\text { havia planejado }\end{array}$ \\
\hline 20 & $\begin{array}{l}\text { Pesquisei muito para definir o nome e a marca da empresa, inclusive me preocupei em saber se } \\
\text { eles já eram usados por outras empresas }\end{array}$ \\
\hline 4 & Busquei informações antes de iniciar a empresa sobre o mercado no qual eu poderia atuar \\
\hline 22 & $\begin{array}{l}\text { A primeira venda da empresa aconteceu para um cliente que se enquadrava exatamente no } \\
\text { público-alvo que eu planejara }\end{array}$ \\
\hline 5 & $\begin{array}{l}\text { Busquei informações antecipadas sobre quais seriam meus concorrentes e com isso refinei meu } \\
\text { conceito de negócio }\end{array}$ \\
\hline \multicolumn{2}{|r|}{ Effectual } \\
\hline 17 & Comecei a empresa com a estrutura mínima possível, sabendo que depois eu poderia melhorá-la \\
\hline 26 & $\begin{array}{l}\text { Procuro assumir alguns riscos ao definir as ações/projetos/iniciativas da empresa, pois assim } \\
\text { posso aproveitar mais oportunidades }\end{array}$ \\
\hline 23 & $\begin{array}{l}\text { As primeiras ações de divulgação da empresa foram feitas boca a boca por pessoas do meu } \\
\text { relacionamento }\end{array}$ \\
\hline 3 & $\begin{array}{l}\text { O conceito do negócio foi construído pouco a pouco em função de adaptações para atender a } \\
\text { possíveis parceiros e clientes }\end{array}$ \\
\hline 12 & $\begin{array}{l}\text { Eu sabia que o valor máximo a ser investido na empresa deveria ser o dinheiro que eu tinha } \\
\text { disponível, mesmo que isso significasse não seguir o melhor para a empresa }\end{array}$ \\
\hline
\end{tabular}

A análise da Tabela 13 permite algumas suposições. Percebe-se que uma das maiores preocupações dos empreendedores é com os recursos financeiros, dessa forma o empreendedor procura monitorar sistematicamente suas contas (atividade 25), opta por começar a empresa com o menor investimento possível (atividade 17) e evita ir atrás de recursos externos (atividade 12). Essa análise conjunta não garante ênfase ao comportamento causal ou effectual, mas demonstra que o empreendedor acredita e monitora o seu planejamento financeiro para não fugir do mesmo, mas não confia o suficiente nele a ponto de arriscar-se investindo mais inicialmente ou buscando recursos de terceiros. Essa análise 
demonstra um comportamento de quem evita o risco, o que é um pouco contraditório, visto que a atividade 26, que foi uma das que demonstrou comportamento mais effectual, afirma que o empreendedor procura assumir alguns riscos.

Sugere-se a realização de estudos futuros com foco nesta contradição para entendê-la melhor. Por hora é possível supor que o empreendedor acredita estar assumindo um risco superior ao de outras pessoas, por ter escolhido criar uma empresa, por isso declara que procura assumir riscos, mas a partir de então seus comportamentos tendem a diminuir o risco, especialmente no que se refere a critérios financeiros. Assim o empreendedor prefere seguir passo a passo com pequenos investimentos, mesmo que isso não maximize seus resultados futuros, de forma que caso a empresa não seja bem sucedida a perda financeira seja menor. É interessante notar esse comportamento tanto para os recursos próprios quanto para os recursos de terceiros.

As atividades também foram analisadas quando agrupadas, conforme previa o Processo Empreendedor. Foi possível identificar que as atividades iniciais do processo são objeto de mais planejamento prévio (média inferior a 5), enquanto as atividades finais têm menos planejamento prévio (média superior a 5), como pode ser visto na Tabela 14. Com isso é possível inferir que o empreendedor inicia o processo mais preocupado em ter um planejamento prévio, mas que, ao final, a prioridade passa a ser a execução.

Esse comportamento que se altera ao longo do processo também merece estudos futuros para ser melhor entendido. Acredita-se que com o tempo o empreendedor possa ganhar confiança na sua atividade e que aprenda com o processo, de modo que passa a agir mais intuitivamente em suas ações, consequentemente necessitando de menor planejamento prévio. Outra análise que pode ser feita está relacionada ao empreendedor perceber que planejar em excesso algumas vezes pode frear o seu crescimento e por isso começa a ter ações mais ágeis.

Tabela 14 - Grupos de atividades do Processo Empreendedor

\begin{tabular}{|l|c|c|c|c|c|}
\hline & & & & \multicolumn{2}{|c|}{ Intervalo de Confiança } \\
\cline { 5 - 6 } & Média & Desvio Padrão & Erro Padrão & Mínimo & Máximo \\
\hline Sub-processo 1 & 4,21 & 1,68 & 0,152 & 4,06 & 4,36 \\
\hline Sub-processo 2 & 4,65 & 1,18 & 0,107 & 4,54 & 4,76 \\
\hline Sub-processo 3 & 4,69 & 1,67 & 0,151 & 4,54 & 4,84 \\
\hline Sub-processo 4 & 5,18 & 1,17 & 0,106 & 5,07 & 5,29 \\
\hline
\end{tabular}




\subsection{Análises multivariadas}

\subsubsection{Análise de Clusters}

A primeira análise multivariada realizada foi a Análise de Clusters, cujo objetivo foi verificar a existência de grupos com comportamentos semelhantes entre os indivíduos da amostra.

O primeiro passo para elaboração dos clusters consistiu em calcular o score em cada um dos quatro sub-processos do processo empreendedor para cada um dos 457 casos estudados. Esse score foi criado usando a média do comportamento do empreendedor em todas as atividades daquele sub-processo.

Elaborados os scores, seguiram-se os procedimentos sugeridos por Hair et al (1998) para Análise de Clusters. Para o cálculo dessas etapas foi utilizado o software SPSS. Primeiramente, foi realizado um agrupamento utilizando-se o Método Hierárquico, com Distância Euclidiana Quadrada e Vínculo entre grupos, que apontou para a solução sugerida da utilização de 3 clusters. Como pode ser observado na Tabela 15 essa é a melhor solução uma vez que apresenta a maior diferença nos resultados dos Coeficientes entre um Estágio e outro $(25,179-21,080=4,099)$.

Tabela 15 - Recorte do resultado do cluster utilizando método hierárquico

\begin{tabular}{|c|c|c|c|c|c|c|}
\hline \multicolumn{7}{|c|}{ Planejamento de aglomeração } \\
\hline \multirow[b]{2}{*}{ Estágio } & \multicolumn{2}{|c|}{ Cluster combinado } & \multirow[b]{2}{*}{ Coeficientes } & \multicolumn{2}{|c|}{$\begin{array}{l}\text { O cluster de estágio é } \\
\text { exibido primeiro }\end{array}$} & \multirow{2}{*}{$\begin{array}{c}\text { Próximo } \\
\text { estágio }\end{array}$} \\
\hline & Cluster 1 & Cluster 2 & & Cluster 1 & Cluster 2 & \\
\hline 445 & 3 & 10 & 13,636 & 442 & 437 & 447 \\
\hline 446 & 6 & 14 & 14,022 & 431 & 335 & 454 \\
\hline 447 & 3 & 13 & 14,519 & 445 & 426 & 449 \\
\hline 448 & 7 & 19 & 15,367 & 0 & 440 & 452 \\
\hline 449 & 3 & 41 & 17,871 & 447 & 428 & 451 \\
\hline 450 & 1 & 5 & 18,220 & 441 & 444 & 452 \\
\hline 451 & 3 & 36 & 18,350 & 449 & 443 & 454 \\
\hline 452 & 1 & 7 & 20,339 & 450 & 448 & 455 \\
\hline 453 & 2 & 35 & 20,926 & 0 & 434 & 455 \\
\hline 454 & 3 & 6 & 21,080 & 451 & 446 & 456 \\
\hline 455 & 1 & 2 & 25,179 & 452 & 453 & 456 \\
\hline 456 & 1 & 3 & 27,120 & 455 & 454 & 0 \\
\hline
\end{tabular}


Uma vez que foi definida a quantidade de clusters que deveriam ser utilizados, foi realizado um novo agrupamento, desta vez pelo método não hierárquico. Esse método apontou a existência do Grupo 1 com 184 indivíduos, do Grupo 2 com 114 indivíduos e do Grupo 3 com 159 indivíduos. A classificação desses grupos segundo a análise dos clusters finais proporcionada pelo software SPSS, pode ser observada na Tabela 16.

Tabela 16 - Centro de Clusters finais

\begin{tabular}{|l|l|c|c|}
\hline \multicolumn{4}{|c|}{ Centros de clusters finais } \\
\cline { 2 - 4 } & \multicolumn{3}{|c|}{ Cluster } \\
\hline Sub-processo 1 & 4,18 & 2 & \multicolumn{1}{c|}{3} \\
Sub-processo 2 & 4,90 & 5,28 & 2,72 \\
Sub-processo 3 & 4,63 & 6,63 & 3,78 \\
Sub-processo 4 & 5,27 & 5,63 & 3,27 \\
\end{tabular}

É possível observar que os 3 grupos são bastante distintos entre si. Para a análise das características de cada um dos grupos, é importante lembrar novamente que quanto menor o score apresentado no sub-processo, maior a quantidade de planejamento prévio existente no comportamento do empreendedor.

O Grupo 3, o qual optou-se denominar empreendedores causais apresenta os indivíduos com maior presença de planejamento prévio. É possível observar que neste grupo, o maior planejamento ocorre no Sub-processo $1 \mathrm{e}$, conforme o processo vai se encaminhando para o final, o nível de planejamento vai sendo reduzido.

O Grupo 2, o qual optou-se denominar empreendedores effectuais foi o que apresentou menor planejamento prévio, ou seja, foi o grupo que contava com indivíduos mais dispostos a agir primeiro e depois enfrentar as consequências. Nesse grupo é interessante observar que o nível de planejamento do Sub-processo 1 é menor que o encontrado no Sub-processo 4. Isso pode significar que ao longo do processo o indivíduo sente a necessidade de aumentar seu nível de planejamento.

O Grupo 1, o qual optou-se denominar empreendedores intermediários, conta com os indivíduos com comportamento entre o Grupo 2 e o 3. Nele estão incluídos os indivíduos que não planejaram tanto quanto os do Grupo 3, mas que também não foram tão impulsivos 
quanto os do Grupo 2. Esses indivíduos começaram planejados, mas ao longo do processo foram ficando mais intuitivos, de modo que no Sub-processo 4 já agiam para enfrentar a consequência mais do que planejavam previamente.

Ao analisar esses 3 grupos, observa-se que indivíduos que declararam ênfase no comportamento causal no início da empresa tendem a diminuir a explicitação deste tipo de comportamento com o passar do tempo, enquanto indivíduos com ênfase no comportamento effectual tendem a tornarem-se mais planejados ao longo do tempo. É possível que todos busquem um meio-termo entre planejamento e execução e que esse meio-termo seja encontrado com o aprendizado natural existente ao longo do processo. Esse pode ser considerado um novo achado desta pesquisa, ainda não identificado em outra publicação existente na literatura científica sobre empreendedorismo que fizeram parte da fundamentação teórica desta tese. Estudos futuros poderão indicar, inclusive, se ao participar de um próximo processo empreendedor, o empreendedor irá agir de maneira semelhante à primeira empresa que criou ou irá agir de maneira diferente, influenciado pelo aprendizado que obteve ao longo do processo.

Na Tabela 17 é apresentada a Tabela ANOVA dos clusters calculada por meio do software SPSS. Nessa tabela é possível observar, por meio da análise dos níveis de significância, que todas as variáveis (sub-processos) são estatisticamente diferentes em todos os três clusters. Esse tipo de análise foi proposto por Hair et al (1998).

Tabela 17 - Tabela ANOVA dos Clusters

\begin{tabular}{|r|r|r|r|r|r|r|}
\hline & \multicolumn{2}{|c|}{ Cluster } & \multicolumn{2}{c|}{ Erro } & \multirow{2}{*}{ F } & \multirow{2}{*}{ Sig. } \\
\cline { 2 - 6 } & Quadrado Médio & Df & Quadrado Médio & Df & & \\
\hline Sub-processo 1 & 420,592 & 2 &, 954 & 454 & 441,067 &, 000 \\
Sub-processo 2 & 101,531 & 2 &, 897 & 454 & 113,148 &, 000 \\
Sub-processo 3 & 375,396 & 2 & 1,044 & 454 & 359,669 &, 000 \\
Sub-processo 4 & 22,423 & 2 & 1,235 & 454 & 18,160 &, 000 \\
\hline
\end{tabular}

Ainda observando a Tabela 17 é possível afirmar que a variável que mais influenciou na formação dos clusters foi a primeira variável, ou seja, Sub-processo 1. Com isso, entende-se que o comportamento que tem maior relevância para a classificação do empreendedor em 
determinado cluster é aquele que ocorre nas ações que estão no início do processo empreendedor.

O Sub-processo 4 é o que menos influenciou a formação dos clusters, ou seja, nas atividades finais do processo os empreendedores classificados em diferentes grupos tendem a ter um comportamento mais semelhante, independente se até aquele momento demonstraram tendência a comportamento mais causal ou effectual.

\subsubsection{Modelagem de Equações Estruturais - Análise da relação perfil $x$ comportamento $x$ desempenho da empresa}

O primeiro procedimento para realização da análise da Modelagem de Equações Estruturais (Structural Equation Modeling) com o método Partial Least Squares (PLS-SEM) foi avaliar se o tamanho da amostra era adequado para a utilização dessa técnica. Concluiu-se que a amostra com 457 casos é adequada para a realização das análises. Segundo Barclay et al (1995) apud Hair et al (2013) a amostra mínima para realizar a PLS-SEM deve ter dez vezes o maior número de indicadores formativos utilizados para medir um único constructo, sendo assim, é possível afirmar que a amostra mínima para o presente estudo seria de 80 casos, número bastante interior aos 457 casos apresentados.

Esse tamanho de amostra respeita também a amostra mínima proposta por Cohen (1992) apud Hair et al (2013) segundo o qual, quando existem 8 variáveis para o mesmo constructo, como no presente estudo, para se obter, com nível de significância de $1 \%$ e $\mathrm{R}^{2}$ mínimo de 0,10 , a amostra mínima deve ter 238 casos, menos que os 457 casos do presente estudo.

Uma vez que o tamanho da amostra foi considerado adequado, partiu-se para a elaboração do modelo a ser testado por meio da PLS-SEM. Todos os cálculos realizados e modelos criados foram feitos com o software SmartPLS 3.0. O primeiro modelo elaborado pode ser observado na Ilustração 12. 


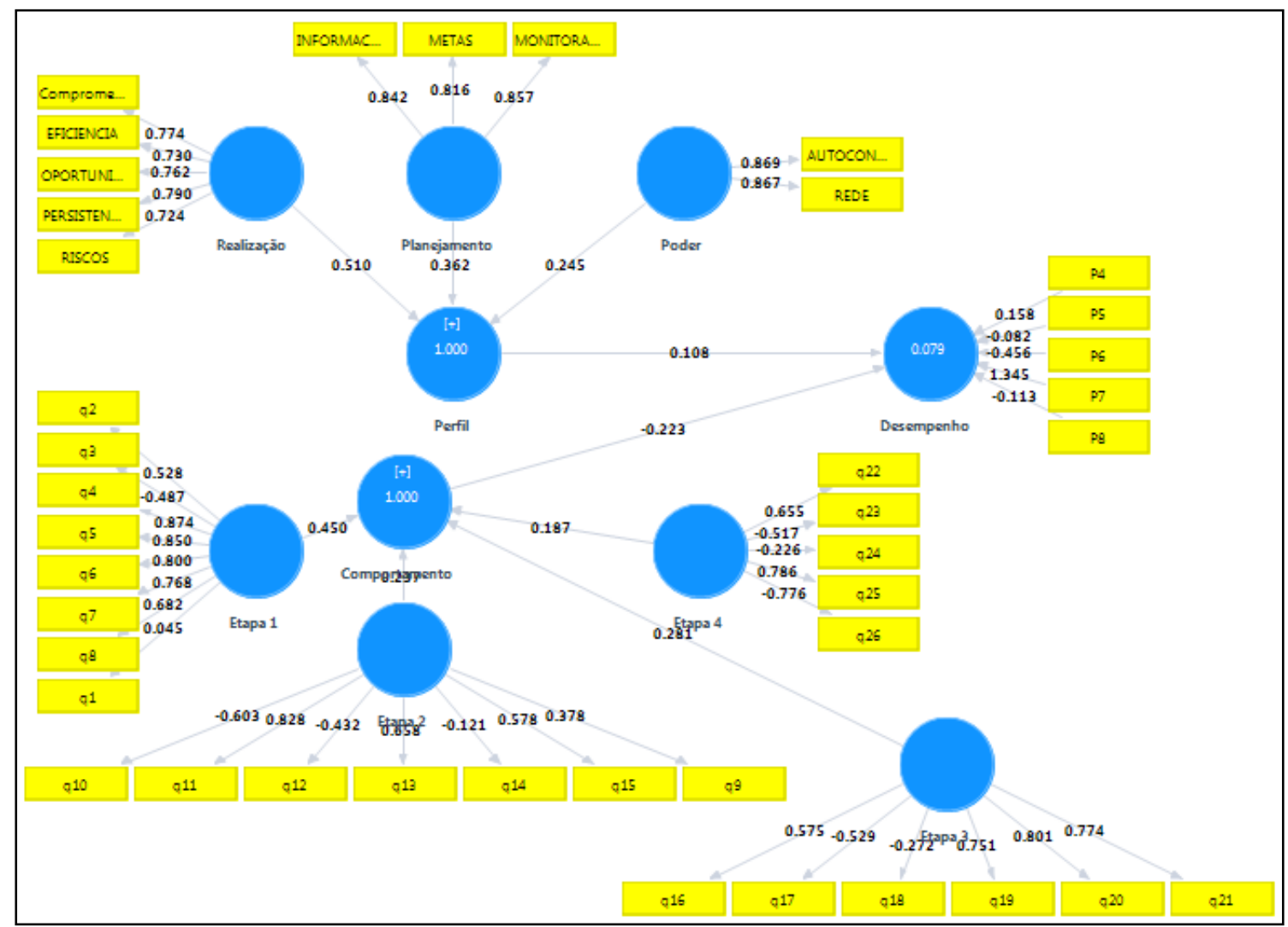

Ilustração 102 - Modelo 01

A primeira ação realizada para verificar a adequação do modelo foi observar as cargas fatoriais das variáveis apresentadas. Segundo Hair et al (2013), a maioria dos especialistas em PLS-SEM determina que as cargas fatoriais devem ser superiores a 0,70. No entanto, Hulland (1999) apud Hair et al (2013) entende que em estudos de ciências sociais, especialmente quando são usadas escalas novas (como é o caso da variável latente Comportamento e da variável latente Desempenho), as cargas fatoriais podem ficar baixas. Neste caso, cargas fatoriais entre 0,4 e 0,7 podem ser aceitáveis. Neste estudo optou-se por considerar apenas cargas fatoriais acima de 0,5, visto que cargas fatoriais muito baixas podem afetar análises posteriores, como a do AVE, por exemplo.

É possível observar que no constructo do Perfil Empreendedor, para o qual foi utilizada uma escala já consolidada para medição, as cargas fatoriais foram mais altas, sendo a menor delas 0,724. Já no constructo Comportamento Empreendedor, as variáveis 1, 3, 9, 12, 14, 18 e 24 apresentaram cargas fatoriais inferiores a 0,5 , e por isso optou-se por removê-las do modelo.

Após excluir as variáveis citadas, o modelo foi testado novamente, conforme pode ser observado na Ilustração 13. 


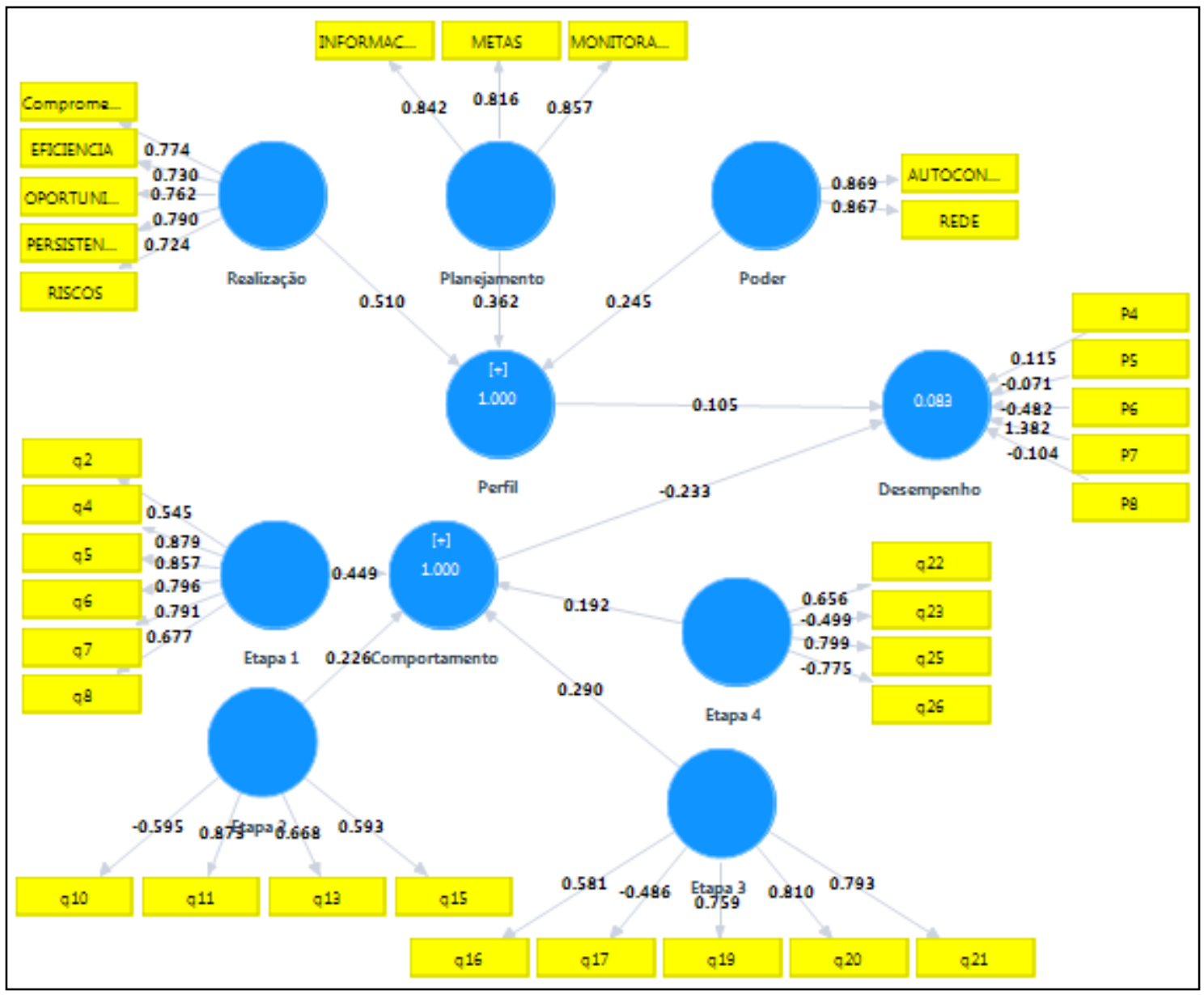

Ilustração 113 - Modelo 02

O Modelo 02, apresentado na Ilustração 13, após as exclusões das variáveis com cargas fatoriais inferiores a 0,5, apresentou duas novas variáveis com cargas fatoriais menores que o aceitável, as variáveis 17 e 23. Dessa forma foi criado um novo modelo, apresentado na Ilustração 14, excluindo-se as variáveis 17 e 23. 


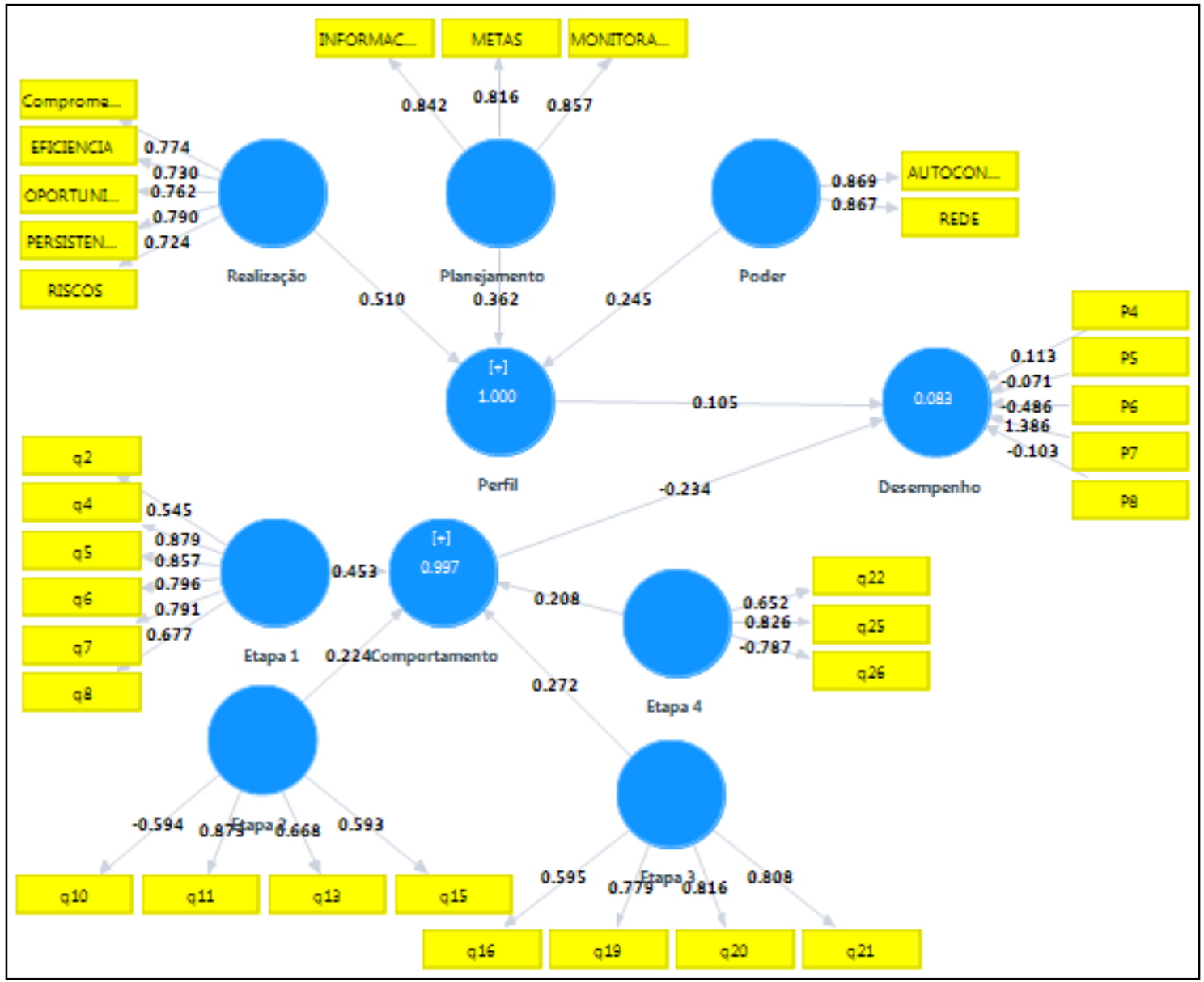

Ilustração 124 - Modelo 03

Uma vez que as cargas fatoriais das variáveis latentes reflexivas mostraram-se adequadas, a próxima análise que foi realizada para avaliar o modelo foi a análise do constructo Desempenho, que era formativo, e não reflexivo como os demais. A primeira análise que deve ser feita neste tipo de constructo refere-se à possibilidade de existência de multicolinearidade entre as variáveis que o compõem. Para realizar essa análise foi utilizado o FIV (Fator de inflação de variância), disponível no software SmartPLS 3.0. Na tabela 18 são apresentados os valores dos FIVs das variáveis que compõem o constructo Desempenho no Modelo 03.

Tabela 18 - FIV

\begin{tabular}{|l|r|}
\hline & \multicolumn{1}{|l|}{ FIV } \\
\hline P4 & 4,903 \\
\hline P5 & 3,99 \\
\hline P6 & 6,604 \\
\hline P7 & 3,617 \\
\hline P8 & 1,582 \\
\hline
\end{tabular}


Não existe um consenso entre os autores sobre os valores de FIV aceitáveis para que a existência de multicolinearidade não seja prejudicial ao modelo. Segundo Hair et al (2013), valores de FIV superiores a 5 representam um problema e devem ser tratados no modelo. Para Bido et al (2010) valores de FIV superiores a 1,43 já sugerem que existe multicolinearidade que afeta os resultados o modelo. Bido et al (2010) realizaram várias simulações e concluíram que, quando os valores de FIV indicam multicolinearidade, a variável latente pode ser tratada como reflexiva ao invés de formativa, com baixo prejuízo no cálculo dos pesos fatoriais. Esse procedimento foi adotado com sucesso por Prearo (2013).

Dessa forma foi criado um novo modelo apresentado na Ilustração 15, em que a variável latente Desempenho foi considerada reflexiva. É possível observar na variável latente Desempenho que as cargas fatoriais nesse caso ficaram adequadas (acima de 0,5), não sendo necessária a exclusão de nenhuma variável.

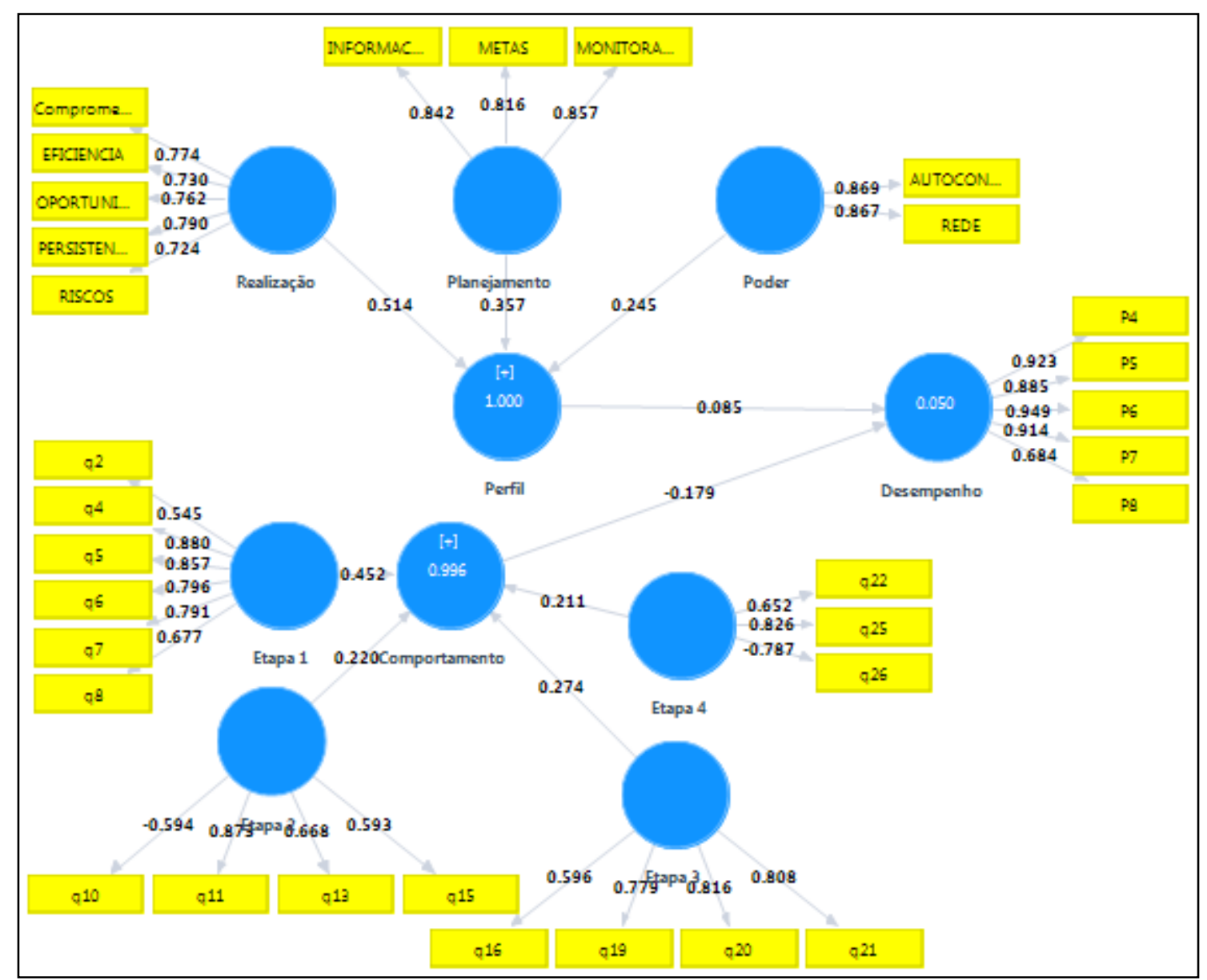

Ilustração 135 - Modelo 04 
Uma vez que a multicolinearidade foi tratada, como próximo passo na análise do modelo observou-se a relação estrutural entre as variáveis latentes, a saber, Perfil Empreendedor, Comportamento Empreendedor e o Desempenho da Empresa. Essa análise foi feita com base no Modelo 04, apresentado na Ilustração 15.

A análise a ser feita é que, quanto mais distante de 0 é o valor da relação estrutural, maior a influência que um constructo possui sobre o outro. Como o valor do Comportamento Empreendedor $(-0,179)$ é maior que o valor da relação do Perfil Empreendedor $(0,085)$, é possível afirmar que o Comportamento Empreendedor exerce mais influência sobre o Desempenho da Empresa do que o Perfil Empreendedor.

O significado de a relação apresentar sinal negativo entre Comportamento Empreendedor e Desempenho da Empresa demonstra que o comportamento causal tem influência positiva no Desempenho da Empresa. Essa afirmação é possível de ser feita, uma vez que a escala que mede o comportamento empreendedor tinha no 0 o comportamento causal e no 10 o comportamento effectual, sendo que o sinal negativo demonstra que a maior influência é feita pelos casos que estavam abaixo de 5, ou seja mais próximos do extremo causal.

O passo seguinte recomendado para analisar o modelo de PLS-SEM foi testar a Confiabilidade dos constructos reflexivos. Esse teste foi realizado por meio do Alfa de Cronbach, disponibilizado pelo software SmartPLS 3.0, e seus resultados são apresentados na Tabela 19. Segundo Hair et al (2013), quando os valores do Alfa de Cronbach são inferiores a 0,60 , isso significa que existe um problema de confiabilidade interna naquele constructo.

Destacam-se o resultado negativo apresentado no Sub-processo 4, o que faz com que esse valor não seja passível de análise e o resultado muito baixo apresentado no Sub-processo 2. Esses valores decorrem do fato de o cálculo do Alfa de Cronbach ser distorcido quando existem variáveis com sinais diferentes em sua composição, como é o caso do Sub-processo 4 e do Sub-processo 2. 
Tabela 19 - Análise da Confiabilidade

\begin{tabular}{|l|r|}
\hline & \multicolumn{2}{|c|}{ Confiabilidade } \\
\hline Sub-processo 1 & 0,853 \\
\hline Sub-processo 2 & 0,150 \\
\hline Sub-processo 3 & 0,745 \\
\hline Sub-processo 4 & $-0,721$ \\
\hline Planejamento & 0,788 \\
\hline Poder & 0,674 \\
\hline Realização & 0,813 \\
\hline
\end{tabular}

Ainda para verificar a qualidade do modelo foi analisada a Validade Convergente, que é a extensão com que uma medida se correlaciona positivamente com medidas alternativas de medir o mesmo constructo (HAIR, et al 2013). Para verificar a Validade Convergente foi utilizado o AVE (Variância Média Extraída), que pode ser observado na Tabela 20. O Subprocesso 2 novamente apresentou problemas. Segundo Hair et al (2013), essa medida deve ser superior a 0,5 .

Tabela 20 - AVE (Validade Convergente)

\begin{tabular}{|l|r|}
\hline & AVE (Validade Convergente) \\
\hline Sub-processo 1 & 0,587 \\
\hline Sub-processo 2 & 0,478 \\
\hline Sub-processo 3 & 0,570 \\
\hline Sub-processo 4 & 0,576 \\
\hline Planejamento & 0,703 \\
\hline Poder & 0,754 \\
\hline Realização & 0,572 \\
\hline
\end{tabular}

Foi ainda analisada a validade discriminante das variáveis latentes por meio do teste de Fornell-Larcker, conforme proposto por Hair et al (2013), utilizando-se o software SmartPLS 3.0. O resultado desse teste é apresentado na Tabela 21. Nessa tabela, os valores das diagonais correspondem aos valores da raiz quadrada do AVE de determinada variável latente e os valores nas linhas e colunas correspondem ao valor da correlação entre as duas variáveis latentes. O ideal é que o valor da diagonal seja superior aos valores das linhas e colunas.

No teste de Fornell-Larcker o único problema apresentado foi entre a variável latente Subprocesso 2 e a variável latente Sub-processo 1. Isso significa que essas duas variáveis latentes podem não ser totalmente distintas uma da outra. 
Tabela 21 - Teste de Fornell-LAcker

\begin{tabular}{|l|l|l|l|l|l|l|l|l|l|l|}
\hline $\begin{array}{l}\text { Validade } \\
\text { Discriminante } \\
\text { (Fornell-Larcker) }\end{array}$ & $\begin{array}{l}\text { Comport } \\
\text { amento }\end{array}$ & $\begin{array}{l}\text { Desempe } \\
\text { nho }\end{array}$ & $\begin{array}{l}\text { Sub- } \\
\text { proces } \\
\text { so 1 }\end{array}$ & $\begin{array}{l}\text { Sub- } \\
\text { proces } \\
\text { so 2 }\end{array}$ & $\begin{array}{l}\text { Sub- } \\
\text { proces } \\
\text { so 3 }\end{array}$ & $\begin{array}{l}\text { Sub- } \\
\text { proces } \\
\text { so 4 }\end{array}$ & Perfil & $\begin{array}{l}\text { Planej } \\
\text { amento }\end{array}$ & $\begin{array}{l}\text { Pod } \\
\text { er }\end{array}$ & $\begin{array}{l}\text { Realiz } \\
\text { ação }\end{array}$ \\
\hline Comportamento & 0.643 & & & & & & & & & \\
\hline Desempenho & -0.206 & 0.876 & & & & & & & & \\
\hline Sub-processo 1 & 0.931 & -0.188 & 0.766 & & & & & & & \\
\hline Sub-processo 2 & 0.855 & -0.173 & 0.732 & 0.692 & & & & & & \\
\hline Sub-processo 3 & 0.860 & -0.163 & 0.711 & 0.648 & 0.755 & & & & & \\
\hline Sub-processo 4 & 0.726 & -0.185 & 0.550 & 0.576 & 0.566 & 0.759 & & & & \\
\hline Perfil & -0.338 & 0.147 & -0.287 & -0.247 & -0.308 & -0.347 & 0.720 & & & \\
\hline Planejamento & -0.420 & 0.168 & -0.367 & -0.336 & -0.374 & -0.379 & 0.872 & 0.838 & & \\
\hline Poder & -0.269 & 0.149 & -0.245 & -0.193 & -0.245 & -0.238 & 0.838 & 0.633 & 0.86 & \\
\hline Realização & -0.237 & 0.098 & -0.186 & -0.155 & -0.222 & -0.298 & 0.939 & 0.700 & $\begin{array}{l} \\
8\end{array}$ & 0.757 \\
\hline
\end{tabular}

Todavia, para certificar-se de que o modelo pode ser utilizado, também é preciso realizar um teste-t utilizando-se o processo de Bootstraping, que neste estudo foi realizado com 500 amostragens. De acordo com Hair et al (2013), os resultados de todas as relações devem ser superiores a 1,96 para que o modelo seja adequado com nível de significância de 5\%, ou superiores a 1,645 para que ele seja adequado com nível de significância de $10 \%$, o que pode ser observado na Ilustração 16. 


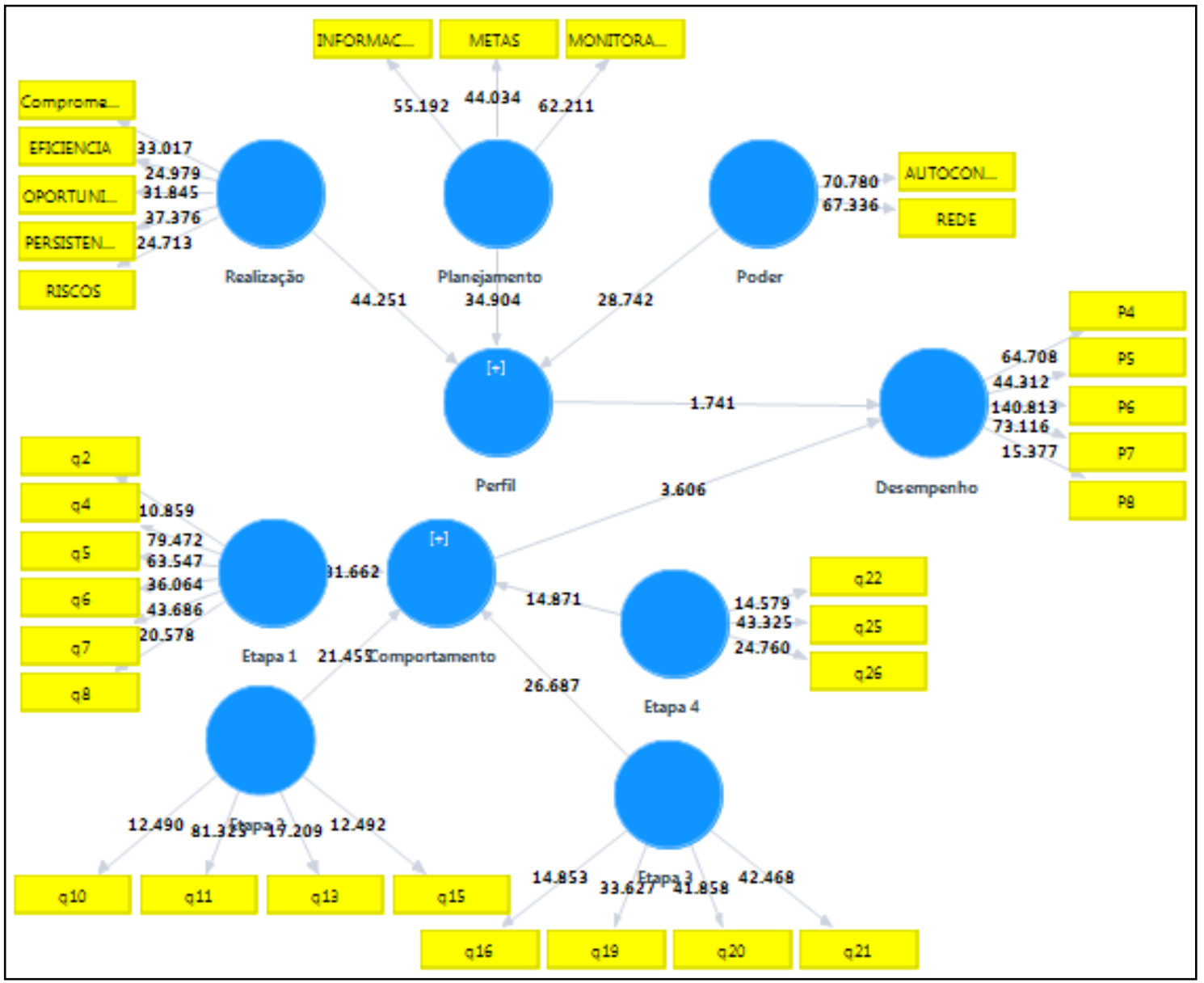

Ilustração 146 - Bootstrapping Modelo 04

A análise dos resultados do procedimento de Bootstrapping permite afirmar que tanto o Perfil do Empreendedor quanto o Comportamento do Empreendedor afetam o Desempenho da Empresa. É possível ainda afirmar que a influência do Comportamento é maior do que do Perfil sobre o Desempenho.

Uma limitação apresentada reside no valor da relação entre o Perfil do Empreendedor e o Desempenho da Empresa. Esse valor permite afirmar que existe relação entre os dois constructos apenas com nível de significância de 10\%, e não com 5\%, como era esperado.

Ao analisar-se o modelo estrutural como um todo, identificou-se que o valor do $\mathrm{R}^{2}$ da variável latente Desempenho da Empresa é baixo. Enquanto os demais constructos apresentaram valores superiores a 0,9 , esse constructo apresentou $R^{2}$ de apenas 0,050 , como pode ser observado na Ilustração 15. Isso significa que além das variáveis utilizadas nessa pesquisa, existem outras que explicam o desempenho da empresa. Estudos futuros podem incluir outras 
variáveis a este modelo aqui apresentado com o objetivo de aumentar o poder de explicação do mesmo sobre essa variável.

Em resumo, o Modelo 04 proposto nesta tese por meio da técnica PLS-SEM permite afirmar que o Perfil do Empreendedor e o Comportamento do Empreendedor afetam positivamente o Desempenho da Empresa criada. Ressalta-se que o comportamento causal tem maior poder de explicar o desempenho positivo da empresa do que o comportamento effectual.

Todavia, o modelo possui alguns valores não tão expressivos em suas análises que poderão ser corrigidas com o aprimoramento das escalas de medição em futuros estudos. Esses valores decorrem principalmente dos constructos que foram medidos por meio de instrumentos novos, criados pelo pesquisador e aplicados pela primeira vez. As inconsistências mais relevantes encontradas são da variável latente Sub-processo 2 que não foi aprovada em alguns dos testes realizados e do $\mathrm{R}^{2}$ da variável Desempenho.

\subsubsection{Modelos alternativos}

Durante os procedimentos para análise do modelo que melhor explicasse os resultados da pesquisa com a utilização das PLS-SEM, foram testados dois modelos alternativos, nos quais a variável latente Comportamento do Empreendedor era a variável mediadora entre o Perfil do Empreendedor e o Desempenho da Empresa. O primeiro dos dois modelos alternativos supunha que existe uma relação direta entre o Perfil do Empreendedor e o Desempenho da Empresa, mas que também existe uma relação mediada pelo Comportamento do Empreendedor. Esse modelo é identificado na Ilustração 17. 


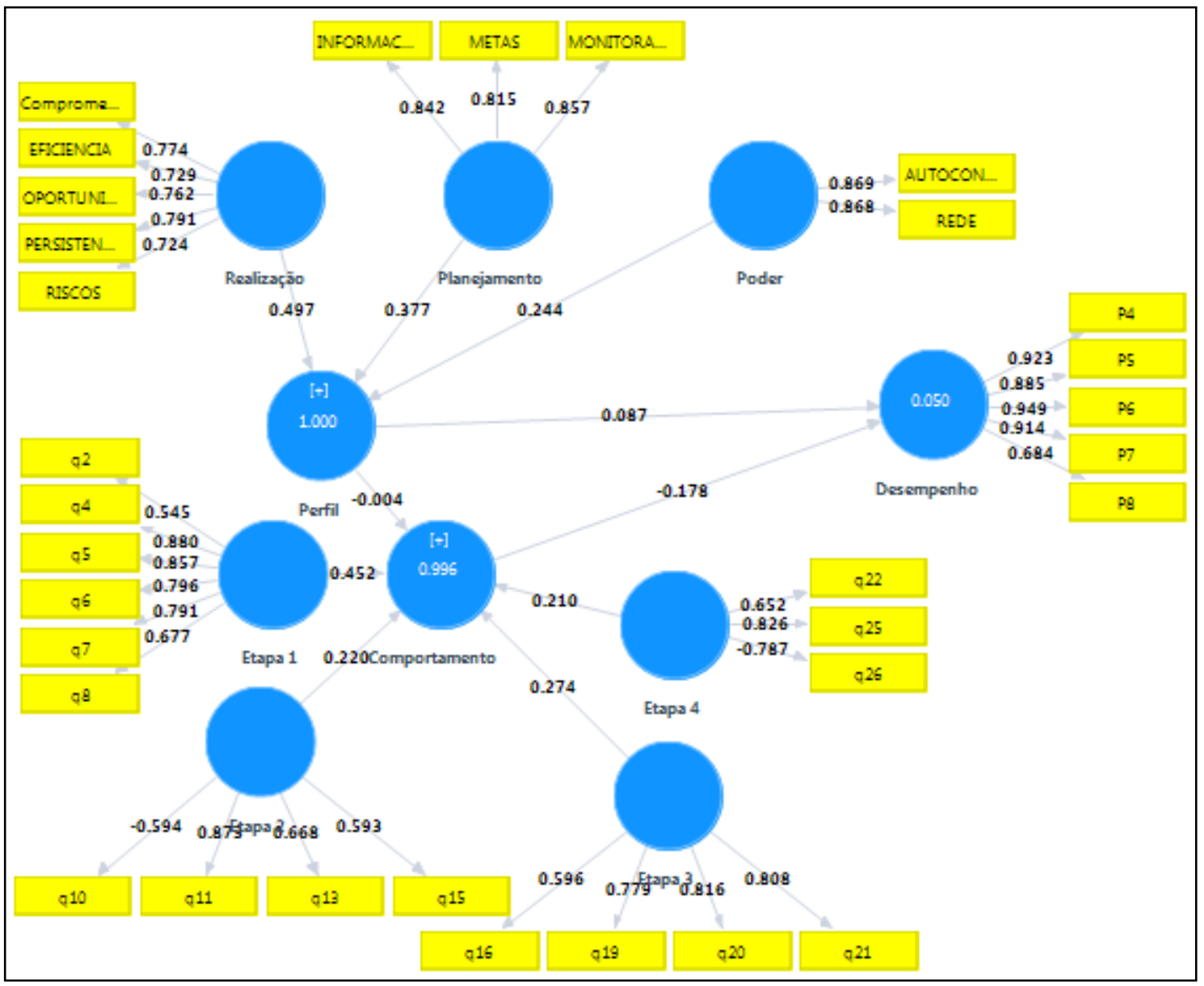

Ilustração 157 - Modelo alternativo 01

Como pode ser observado na Ilustração 17, neste modelo alternativo a relação estrutural entre Perfil e Comportamento ficou muito baixa $(-0,004)$, mas ainda assim testou-se o modelo por meio do Bootstrapping, cujo resultado é apresentado na Ilustração 18. A relação ficou ainda mais baixa $(1,084)$ que no primeiro modelo, demonstrando que esse modelo é menos adequado que o primeiro modelo proposto. 


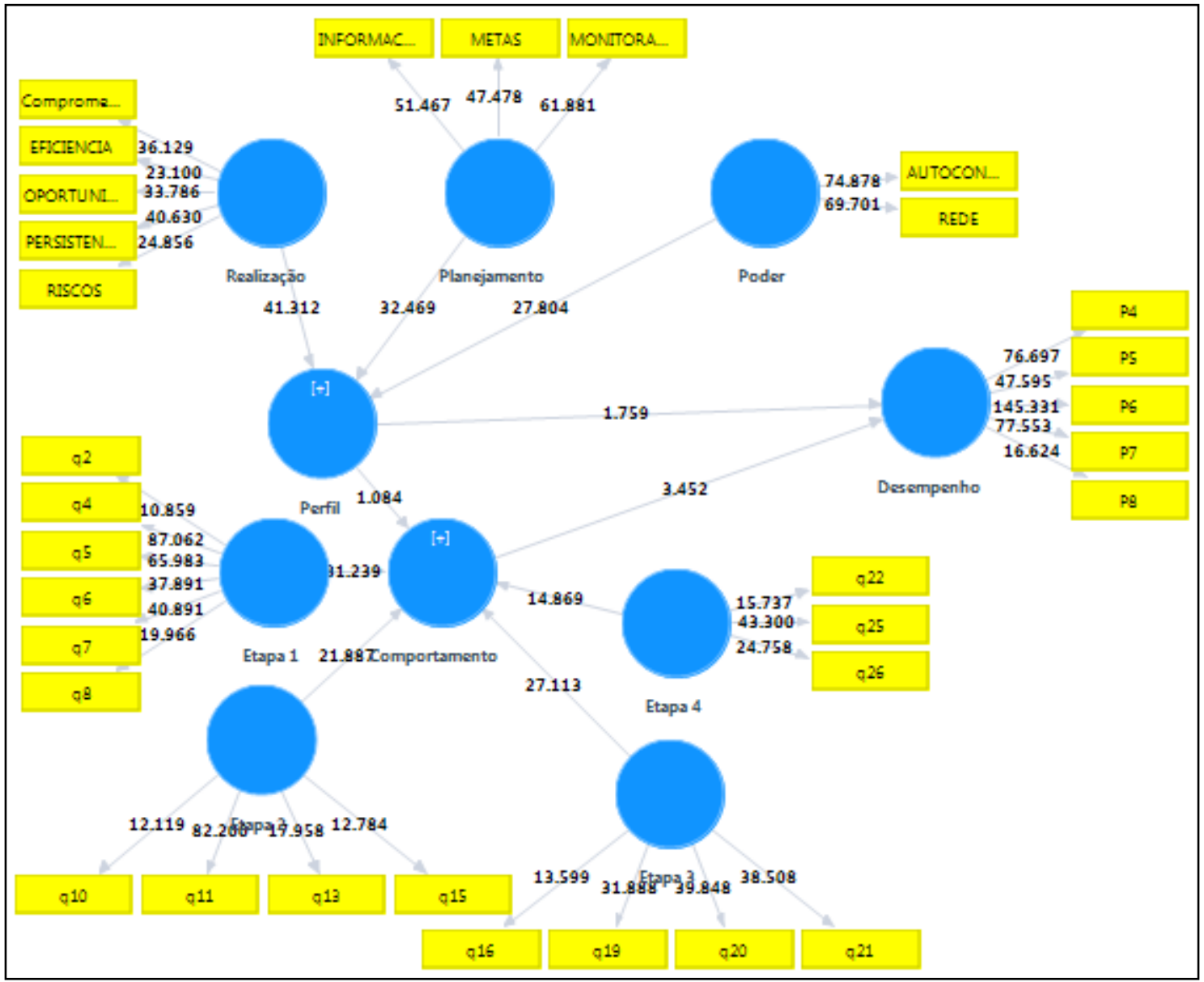

Ilustração 168 - Bootstrapping Modelo alternativo 01

Também foi testado um terceiro modelo, em que a única relação entre Perfil do Empreendedor e Desempenho da Empresa era mediada pelo Comportamento do Empreendedor, não existindo relação direta entre as duas variáveis. Esse modelo também apresentou relação estrutural muito baixa $(-0,004)$ entre as variáveis latentes, como pode ser observado na Ilustração 19. 


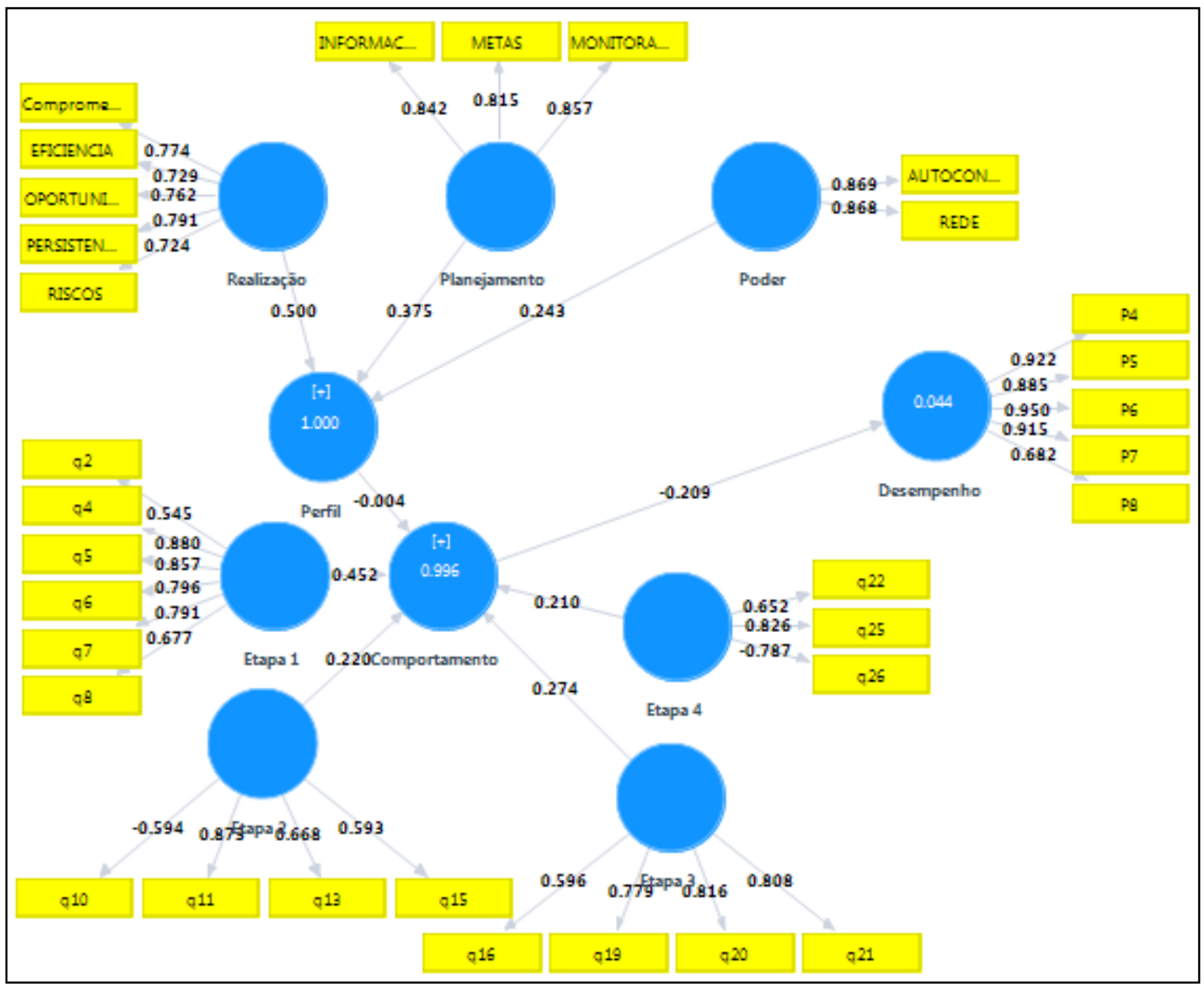

Ilustração 179 - Modelo alternativo 02

Apenas para garantir que esse modelo não seria adequado, foi feito o Bootstrapping do mesmo, cujo resultado é apresentado na Ilustração 20 e comprova o resultado inadequado, ainda menor que no modelo anterior. 


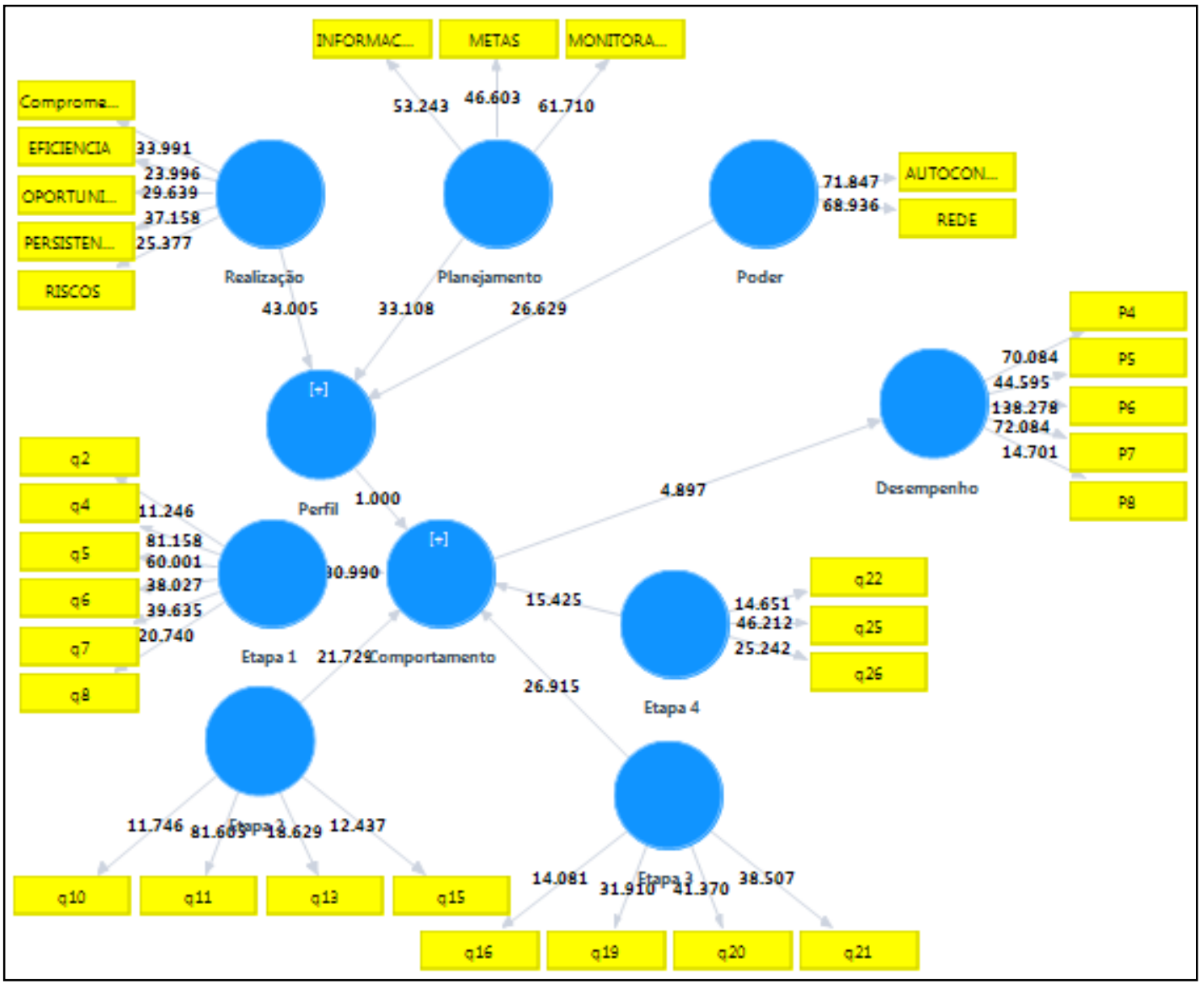

Ilustração 2018 - Bootstrapping Modelo alternativo 02

Como os dois modelos alternativos apresentados demonstraram resultados inferiores ao modelo original, especialmente nas relações entre as variáveis latentes, entende-se que o primeiro modelo apresentado, embora tenha limitações, é o modelo mais adequado para medir a relação entre as 3 variáveis latentes apresentadas neste estudo.

\subsubsection{Análise Multigrupos}

Visto que as empresas resultantes dos processos empreendedores pesquisadas eram muito diversas, optou-se por fazer uma análise dos diferentes setores de atuação dos negócios, a fim de verificar se existiam diferenças entre eles. Foi possível comparar os grupos Comércio Tradicional e Serviço, que apresentavam quantidades de respondentes suficientes para formarse uma amostra mínima necessária para realização do procedimento da PLS-SEM (A Tabela 06 apresenta a quantidade de casos em cada um dos setores de atuação). A análise multigrupos foi realizada utilizando-se o software SmartPLS 3.0 na sua função Análises Multigrupos. 
Um dos principais problemas apresentados no modelo quando analisado com a amostra completa foi o problema do $\mathrm{R}^{2}$, ou seja, as variáveis utilizadas no modelo para medir o desempenho explicavam pouco do mesmo. Esse problema foi amenizado na amostra que continha apenas empresas de Comércio Tradicional, como pode ser observado na Tabela 22. $\mathrm{O} \mathrm{R}^{2}$ dessa amostra ficou em 0,261 , valor considerado adequado para o $\mathrm{R}^{2}$ (Segundo Hair et al (2013) valores de $\mathrm{R}^{2}>0,2$ são aceitáveis) e bastante superior ao 0,050 apresentado no Modelo 04 com a amostra completa.

Tabela 22 - $\mathbf{R}^{2}$ Análise Multigrupos

\begin{tabular}{|l|l|l|l|l|l|l|}
\hline & $\begin{array}{l}\text { R-Square } \\
\text { Mean } \\
\text { (Comércio) }\end{array}$ & $\begin{array}{l}\text { R-Square } \\
\text { Mean } \\
\text { (Serviço) }\end{array}$ & $\begin{array}{l}\text { t-Values } \\
\text { (Comércio) }\end{array}$ & $\begin{array}{l}\text { t-Values } \\
\text { (Serviço) }\end{array}$ & $\begin{array}{l}\text { p-Values } \\
\text { (Comércio) }\end{array}$ & $\begin{array}{l}\text { p-Values } \\
\text { (Serviço) }\end{array}$ \\
\hline Comportamento & 0.996 & 0.996 & 594.717 & $1,095.761$ & 0.000 & 0.000 \\
\hline Desempenho & 0.261 & 0.048 & 3.041 & 1.656 & 0.002 & 0.098 \\
\hline Perfil & 1.000 & 1.000 & $22,199.035$ & $107,467.310$ & 0.000 & 0.000 \\
\hline
\end{tabular}

Já o $\mathrm{R}^{2}$ no grupo de empresas de Serviços ficou menor que o 0,050 da amostra original, demonstrando que esse grupo pode ter sido um dos motivos de ter puxado o $\mathrm{R}^{2}$ da amostra completa para baixo. É possível afirmar portanto que as variáveis utilizadas neste estudo para medir o constructo Desempenho da Empresa são mais bem adaptadas para analisar Comércio Tradicional, enquanto para Serviço elas não medem adequadamente.

Foi analisada também a Confiabilidade das variáveis latentes de cada um dos dois grupos (Comércio Tradicional e Serviço), por meio do Alfa de Cronbach. O resultado dessa análise é apresentado na Tabela 23. É possível observar que a variável latente Sub-processo 2 segue apresentando valores muito pequenos em ambos os grupos, embora apresente um valor maior do que o valor da amostra completa para o grupo de Comércio Tradicional. A variável latente Sub-processo 4 também continua apresentando valores negativos. Dessa forma é possível afirmar que a Confiabilidade do Sub-processo 2 e do Sub-processo 4 seguem distorcidas pela existência de variáveis com sinais diferentes em sua composição, não sendo possível realizar sua análise. 
Tabela 23 - Teste de Confiabilidade Multigrupos

\begin{tabular}{|l|r|r|}
\hline & $\begin{array}{l}\text { Cronbachs Alpha Mean (Comércio } \\
\text { Tradicional) }\end{array}$ & Cronbachs Alpha Mean (Serviço) \\
\hline Sub-processo 1 & 0.830 & 0.869 \\
\hline Sub-processo 2 & 0.313 & -0.005 \\
\hline Sub-processo 3 & 0.757 & 0.755 \\
\hline Sub-processo 4 & -1.333 & -1.047 \\
\hline Planejamento & 0.810 & 0.788 \\
\hline Poder & 0.667 & 0.686 \\
\hline Realização & 0.849 & 0.800 \\
\hline
\end{tabular}

Utilizou-se novamente o AVE para testar a Validade Convergente nos dois grupos. Observam-se os resultados deste teste nos grupos na Tabela 24. Nessa análise identifica-se que o Sub-processo 2 ainda apresenta problemas em ambos os grupos, embora o grupo de Serviços apresente valor melhor que a amostra completa.

Tabela 24 - Validade Convergente Multigrupos

\begin{tabular}{|l|r|r|}
\hline & AVE Mean (Comércio) & AVE Mean (Serviço) \\
\hline Sub-processo 1 & 0.568 & 0.613 \\
\hline Sub-processo 2 & 0.477 & 0.490 \\
\hline Sub-processo 3 & 0.597 & 0.582 \\
\hline Sub-processo 4 & 0.528 & 0.634 \\
\hline Planejamento & 0.729 & 0.703 \\
\hline Poder & 0.753 & 0.761 \\
\hline Realização & 0.632 & 0.558 \\
\hline
\end{tabular}

Também foram observadas as relações entre os constructos, cujos resultados estão apresentados na Tabela 25. É possível observar que a relação entre Comportamento do Empreendedor e Desempenho da Empresa é mais bem explicada no setor de Comércio Tradicional do que na amostra completa, e especialmente do que no setor de Serviço. É possível observar também que a relação entre Perfil do Empreendedor e Desempenho da Empresa é muito baixa para o segmento de Comércio Tradicional, enquanto para o segmento de Serviço ela é bem superior à da amostra completa.

A análise da Tabela 25 permite inferir que para as empresas de Comércio o Comportamento do Empreendedor tem grande influência no Desempenho da Empresa e o Perfil do Empreendedor tem influência pouco relevante. Já para as empresas de Serviços, a influência do Perfil e a do Comportamento são pequenas e muito semelhantes. 
As análises acima permitem algumas conjecturas, dentre elas é possível que para os empreendedores do setor de comércio, onde normalmente os investimentos são maiores e o consumidor recebe produtos previamente criados (ou adquiridos), o comportamento do empreendedor durante o processo seja mais importante do que necessariamente seu perfil de empreendedor. Já no caso do setor de serviços, onde as primeiras entregas, em especial, são muitas vezes desenvolvidas em conjunto com o cliente, não é tão importante o comportamento do empreendedor durante o processo, mas sim que ele tenha um perfil empreendedor. Estudos futuros poderão identificar essas diferenças existentes entre os dois grupos.

Tabela 25 - Relação entre os Constructos Multigrupos

\begin{tabular}{|c|c|c|c|c|}
\hline & \begin{tabular}{|l|l|l|l} 
Path Coefficients \\
(Comércio)
\end{tabular} & Mean & \begin{tabular}{|l} 
Path Coefficients \\
(Serviço)
\end{tabular} & Mean \\
\hline Comportamento -> Desempenho & & -0.482 & & -0.128 \\
\hline Sub-processo 1 -> Comportamento & & 0.392 & & 0.449 \\
\hline Sub-processo 2 -> Comportamento & & 0.265 & & 0.214 \\
\hline Sub-processo 3 -> Comportamento & & 0.268 & & 0.263 \\
\hline Sub-processo 4 -> Comportamento & & 0.188 & & 0.230 \\
\hline Perfil -> Desempenho & & -0.020 & & 0.114 \\
\hline Planejamento -> Perfil & & 0.345 & & 0.365 \\
\hline Poder -> Perfil & & 0.232 & & 0.252 \\
\hline Realização -> Perfil & & 0.514 & & 0.508 \\
\hline
\end{tabular}

$\mathrm{Na}$ tabela 26, por meio do teste $\mathrm{t}$ (feito pelo processo de Bootstrapping pelo software SmartPLS 3.0) da relação entre os constructos, é possível observar que o modelo é bastante fraco para explicar o Desempenho das empresas do setor de serviço, visto que tanto a relação Comportamento - Desempenho quanto a relação Perfil - Desempenho apresentaram valores bem inferiores a 1,96. Já na análise do setor de Comércio Tradicional é possível afirmar que existe uma relação bastante forte entre Comportamento - Desempenho, mas que a relação Perfil - Desempenho é muito fraca. 
Tabela 26 - Teste t da relação entre os constructos Multigrupos

\begin{tabular}{|l|r|r|}
\hline & t-Values (Comércio) & t-Values (Serviço) \\
\hline Comportamento -> Desempenho & 4.563 & 1.762 \\
\hline Sub-processo 1 -> Comportamento & 11.401 & 22.805 \\
\hline Sub-processo 2 -> Comportamento & 12.674 & 16.520 \\
\hline Sub-processo 3 - Comportamento & 9.497 & 21.262 \\
\hline Sub-processo 4 -> Comportamento & 4.659 & 14.665 \\
\hline Perfil -> Desempenho & 0.249 & 1.581 \\
\hline Planejamento -> Perfil & 15.855 & 25.491 \\
\hline Poder -> Perfil & 14.049 & 20.151 \\
\hline Realização -> Perfil & 22.889 & 30.481 \\
\hline
\end{tabular}

Também foi realizado o teste $\mathrm{p}$ das relações entre os constructos nos dois grupos, cujo resultado é apresentado na Tabela 27. Esse resultado corrobora o que já foi apresentado no teste t.

Tabela 27 - Teste p da relação entre os constructos Multigrupos

\begin{tabular}{|l|r|r|}
\hline & p-Values (Comércio) & p-Values (Serviço) \\
\hline Comportamento -> Desempenho & $\mathrm{p}<0,01$ & 0.080 \\
\hline Sub-processo 1 -> Comportamento & $\mathrm{p}<0,01$ & $\mathrm{p}<0,01$ \\
\hline Sub-processo 2 -> Comportamento & $\mathrm{p}<0,01$ & $\mathrm{p}<0,01$ \\
\hline Sub-processo 3 -> Comportamento & $\mathrm{p}<0,01$ & $\mathrm{p}<0,01$ \\
\hline Sub-processo 4 -> Comportamento & $\mathrm{p}<0,01$ & $\mathrm{p}<0,01$ \\
\hline Perfil -> Desempenho & 0.942 & 0.103 \\
\hline Planejamento -> Perfil & $\mathrm{p}<0,01$ & $\mathrm{p}<0,01$ \\
\hline Poder -> Perfil & $\mathrm{p}<0,01$ & $\mathrm{p}<0,01$ \\
\hline Realização -> Perfil & $\mathrm{p}<0,01$ & $\mathrm{p}<0,01$ \\
\hline
\end{tabular}

Com todas as análises realizadas nos dois grupos é possível afirmar que, de maneira geral, o modelo é mais explicativo para o setor de atuação de Comércio Tradicional do que para o setor de atuação de Serviços. Inclusive o modelo é mais adequado para o setor de Comércio Tradicional do que para a amostra contendo todos os indivíduos. É possível afirmar ainda que o Comportamento do Empreendedor tem forte influência no Desempenho para o Comércio Tradicional, mas que o Perfil do Empreendedor não tem influência no desempenho neste setor.

Suspeita-se que as variáveis utilizadas para medir o Desempenho da Empresa sejam mais adequadas para o setor de Comércio Tradicional do que para o setor de Serviços e também os 
demais setores da pesquisa. Isso pode esclarecer o maior poder de explicação do modelo como um todo para este setor de Comércio Tradicional do que para os demais setores. Estudos futuros podem buscar ferramentas específicas para medir o desempenho de empresas do setor de Serviços e testar o modelo proposto nesta tese.

\subsubsection{Comércio Tradicional $x$ Serviços}

Após a análise do modelo com cada um dos dois grupos (Setor de atuação: Comércio Tradicional e Serviço), faz-se necessária a análise da comparação entre os grupos, buscando responder à questão se existem diferenças estatisticamente significantes entre os dois modelos. Hair et al (2013) entende que essa análise pode ser feita utilizando-se o teste paramétrico, ou ainda que uma análise mais aprofundada pode ser feita utilizando-se o teste de Henseler.

De acordo com Hair et al (2013, p.255), quando p<0,05, é possível afirmar que existe diferença estatística significante entre os grupos. De acordo com o teste paramétrico apresentado na Tabela 28, é possível afirmar que no presente estudo existem diferenças significativas na relação entre os constructos Comportamento e Desempenho e entre os constructos Sub-processo 2 e Comportamento.

Tabela 28 - Teste paramétrico (Comércio vs Serviço)

\begin{tabular}{|l|c|c|}
\hline Teste Paramétrico & t-Value (Comércio vs Serviço) & p-Value (Comércio vs Serviço) \\
\hline Comportamento -> Desempenho & 2.562 & 0.011 \\
\hline Sub-processo 1 -> Comportamento & 1.441 & 0.151 \\
\hline Sub-processo 2 -> Comportamento & 1.972 & 0.049 \\
\hline Sub-processo 3 -> Comportamento & 0.232 & 0.816 \\
\hline Sub-processo 4 -> Comportamento & 1.171 & 0.242 \\
\hline Perfil -> Desempenho & 0.882 & 0.378 \\
\hline Planejamento -> Perfil & 0.726 & 0.468 \\
\hline Poder -> Perfil & 0.809 & 0.419 \\
\hline Realização -> Perfil & 0.195 & 0.846 \\
\hline
\end{tabular}

De acordo com Hair et al (2013), o teste paramétrico, exige que ambos os grupos tenham distribuição normal, o que não é sempre verdade nos casos em que se utiliza a PLS. Nesse caso, os autores sugerem a realização de um teste não paramétrico, em especial o teste de 
Henseler (2007), para procurar diferenças estatisticamente significantes em amostras que não tenham necessariamente distribuição normal.

Os resultados do Teste de Henseler (2007) feito a partir do software SmartPLS 3.0 são apresentados na Tabela 29 e demonstram que apenas há diferença significativamente relevante entre os grupos na relação entre o Sub-processo 2 e o Comportamento.

Tabela 29 - Teste de Henseler (2007)

\begin{tabular}{|l|c|c|}
\hline Henseler's MGA & $\begin{array}{c}\text { Path Coefficients-diff } \\
(\mid \text { Comércio - Serviço })\end{array}$ & $\begin{array}{c}\text { p-Value } \\
\text { (Comércio vs Serviço) }\end{array}$ \\
\hline Comportamento -> Desempenho & 0.357 & 0.996 \\
\hline Sub-processo 1 -> Comportamento & 0.054 & 0.920 \\
\hline Sub-processo 2 -> Comportamento & 0.053 & 0.018 \\
\hline Sub-processo 3 -> Comportamento & 0.006 & 0.416 \\
\hline Sub-processo 4 -> Comportamento & 0.042 & 0.827 \\
\hline Perfil -> Desempenho & 0.119 & 0.815 \\
\hline Planejamento -> Perfil & 0.021 & 0.791 \\
\hline Poder -> Perfil & 0.020 & 0.836 \\
\hline Realização -> Perfil & 0.006 & 0.408 \\
\hline
\end{tabular}

Com a realização dos dois testes (paramétrico e não paramétrico) é possível afirmar que a única diferença estatisticamente significante entre os dois grupos analisados (Comércio e Serviços) ocorreu na relação entre o Sub-processo 2 e o Comportamento.

Não foram feitas análises para Comércio Eletrônico, para Agricultura e para Indústria pois a quantidade de indivíduos desses setores de atuação que responderam ao questionário não era suficiente para a existência de uma amostra mínima necessária para análise por meio da SEMPLS. 


\section{CONCLUSÕES DA PESQUISA}

Neste capítulo estarão detalhadas as principais conclusões da tese, assim como suas limitações .

\subsection{Perfil do empreendedor}

O primeiro objetivo desta pesquisa consistiu em identificar as características do perfil empreendedor mais presentes na amostra pesquisada. Essas características foram analisadas por meio do teste de perfil empreendedor criado por McClelland (1987) e amplamente utilizado desde então por diversos estudos.

Identificou-se que o conjunto de características com maior presença é o ligado ao planejamento (orientado por objetivos, pesquisador de informações, planejador e controlador). Essa conclusão pode ser obtida tanto ao analisar a característica mais presente em cada indivíduo (independentemente do nível de presença de cada característica) quanto ao analisar o nível de presença de cada característica.

Esperava-se, baseado nos estudos anteriores, que o perfil dos empreendedores fosse predominantemente realizador ou planejador, como efetivamente se demonstrou. Acredita-se que o fato de a amostra ter sido retirada de uma população de indivíduos cadastrados em um portal chamado Plano de Negócios possa ter influenciado para a maior prevalência de empreendedores que se preocupam com o planejamento.

\subsection{Comportamento do empreendedor}

O segundo objetivo desta pesquisa consistia em analisar o comportamento predominante dos empreendedores durante a condução do processo empreendedor. Buscou-se encontrar este comportamento em cada uma das vinte e seis atividades identificadas como cruciais em todos os processos empreendedores e também em cada um dos quatro sub-processos nos quais essas atividades foram agrupadas. 
O comportamento dos empreendedores pode tomar dois extremos durante a condução do processo. Em um extremo está o comportamento causal, fortemente ancorado em um planejamento prévio de todas as ações e na maximização do retorno financeiro futuro. No outro extremo encontra-se o comportamento effectual, baseado na execução momentânea e na minimização dos riscos no curto prazo.

$\mathrm{Na}$ análise de cada uma das atividades do empreendedor foi possível identificar que ele realiza dezesseis delas com mais ênfase causal, e apenas dez com ênfase effectual. Essa análise demonstra que dentre os empreendedores da amostra selecionada para este estudo, o comportamento causal, ou seja, planejado a priori é predominante. Esse resultado pode também ter influência da população selecionada para retirar a amostra da pesquisa, composta de indivíduos de um portal com conteúdo de planejamento.

A predominância encontrada do comportamento planejado não corrobora a teoria até então proposta, especialmente os estudos de Sarasvathy (1998) e Dew et al (2008), que acreditam que os empreendedores agem na maioria das vezes de forma effectual. É possível que essa distinção ocorra em função do universo de onde a amostra foi extraída ou, ainda, pelo perfil dos empreendedores da amostra, em que prevaleciam empreendedores com elevado grau de instrução. Outra possível suposição para essa diferença é o ambiente cultural onde os empreendedores desta pesquisa e dos autores citados estão inseridos, sendo que esta tese envolve empreendedores brasileiros e os trabalhos citados, empreendedores americanos.

Quando analisado o comportamento dos empreendedores por meio do agrupamento das vinte e seis atividades em quatro sub-processos, foi possível identificar que no início o comportamento tende a ser mais causal, tornando-se mais effectual ao longo do processo. Essa descoberta traz um novo achado para a teoria do empreendedorismo, demonstrando que o comportamento do empreendedor não se apega a um extremo e segue nele durante todo o processo, mas, sim, que existe um comportamento que vai mudando ao longo do processo.

Foi analisada, também, a possível existência de grupos de empreendedores com padrões semelhantes. Essa análise foi conduzida com uma análise de clusters que apontou a existência de três grupos distintos. Um primeiro grupo conta com os empreendedores mais causais. Esse 
grupo inicia o processo com bastante foco no planejamento e assim se mantém até o final, embora vá tornando-se menos causal no seu decorrer.

Um segundo grupo de empreendedores tende a ter comportamento mais effectual. Esse grupo também retrata mudança de comportamento ao longo do processo, sendo que é extremamente causal na primeira etapa do processo, mas tende a ter um comportamento menos effectual na última.

O terceiro grupo contou com os empreendedores que mantêm um comportamento intermediário. Esse grupo tem empreendedores que iniciam o processo de maneira mais causal (embora menos causal que o primeiro grupo) e que vão tornando-se menos causal ao longo do processo, até que no Sub-processo 4 assumem um comportamento mais effectual.

Esta pesquisa, ao conseguir caracterizar grupos de empreendedores com comportamentos bem definidos, traz um novo achado à teoria de comportamento empreendedor. Este achado precisará ainda ser testado em outras amostras de empreendedores, mas pode identificar a existência de grupos com comportamento padrão, que devem ser trabalhados de formas distintas, seja com relação ao ensino que irão receber, seja com relação aos apoios e suportes.

O terceiro objetivo desta tese pretendia identificar a influência do comportamento do tipo effectual ou do tipo causal durante o processo empreendedor no desempenho da empresa criada.

O Modelo 4, apresentado na Ilustração 15, permitiu afirmar que existe influência positiva do tipo de comportamento causal no desempenho da empresa. Esse resultado corrobora com os pesquisadores que defendem a necessidade de planejamento prévio para aumentar as chances de sucesso do empreendedor.

\subsection{Relação Perfil $x$ Comportamento $x$ Desempenho}


O quarto e principal objetivo desta tese consistiu em identificar a relação existente entre os constructos Perfil do Empreendedor, Comportamento do Empreendedor e Desempenho da Empresa criada, além de propor um modelo teórico que identifique a relação entre estes.

Para atender a esse objetivo, foi criado e testado um modelo utilizando o método da PLSSEM. O primeiro passo para a criação desse modelo sugeriu a exclusão de algumas variáveis relacionadas ao constructo Comportamento do Empreendedor, ou seja, este modelo sugere que algumas das atividades do processo empreendedor não têm relevância estatística na formação do comportamento do sub-processo a que essa atividade se refere.

O segundo passo para a criação do modelo consistiu em realizar diversos testes propostos por Hair et al (2013) a fim de verificar a qualidade do modelo proposto. Foram identificados alguns problemas no modelo, mas, de modo geral, o mesmo pode ser aceito como um modelo inicial a ser testado em novos estudos futuros.

O modelo apresentado reforça o Perfil Empreendedor como um constructo passível de ser medido utilizando-se as dez características propostas por McClelland e seu futuro agrupamento em três grupos.

Este mesmo modelo também representa a possibilidade de se medir o Comportamento Empreendedor por meio das atividades listadas nesta tese. Embora tenha sido necessária a exclusão de algumas atividades no modelo final, isso é aceitável devido a ser um modelo inicial, que deve ser aprimorado em pesquisas futuras.

Buscou-se também criar uma maneira para medir o Desempenho da Empresa criada, essa medida, embora não tenha sido necessária a exclusão de nenhuma variável, resultou em poder de explicação muito baixo, o que demonstra que pode ser aprimorada futuramente. Esse problema pode decorrer do fato de ter se buscado utilizar medidas que fossem as mais amplas possíveis para medir negócios de setores totalmente diferentes.

No que se refere às relações entre os constructos, o modelo demonstrou que tanto o Comportamento quanto o Perfil do Empreendedor influenciam no Desempenho da Empresa criada. Foi constatado que o Comportamento tem influência maior do que o Perfil e que o 
Comportamento que tem maior poder de explicação do Desempenho é o comportamento causal.

Com isso é possível dizer que se rejeita as duas hipótese nulas apresentadas e afirma-se que existem evidências de que o Perfil do Empreendedor e o Comportamento do Empreendedor durante o processo de criação da empresa influenciam o Desempenho da mesma.

Foram ainda realizados testes com modelos alternativos que incluíssem a mediação da relação entre Perfil Empreendedor e Desempenho da Empresa pelo constructo Comportamento do Empreendedor, no entanto esses modelos apresentaram relações piores que o primeiro modelo testado.

Também foram analisados modelos apenas para as empresas do setor de comércio tradicional e para o setor de serviços. O modelo ficou mais bem ajustado para o setor de comércio tradicional que para a amostra completa analisada. No setor de comércio tradicional não existiu problema na medição do constructo Desempenho e a relação entre o Comportamento e o Desempenho apareceu ainda mais forte do que no modelo geral.

No modelo testado apenas com empresas de serviço, o $\mathrm{R}^{2}$ do Desempenho apareceu ainda menor do que no modelo geral, o que aponta que isso pode ter sido responsável pela diminuição do $\mathrm{R}^{2}$ no modelo geral.

Em resumo é possível afirmar que esta tese apresenta um modelo inicial para demonstrar a relação entre Perfil do Empreendedor, Comportamento do Empreendedor e Desempenho da Empresa criada. Esse modelo mostra-se ainda mais adequado quando aplicado apenas a empresas que se declaram do setor de Comércio Tradicional.

\subsection{Limitações da pesquisa}

É preciso declarar que, assim como todos os estudos científicos, este também possui limitações que serão listadas a seguir e que podem ser aprimoradas em estudos futuros. 
A amostra selecionada para a pesquisa foi definida usando-se o critério de conveniência e consiste nos usuários de um portal de negócios na internet. Dessa forma, ela não permite que os resultados sejam generalizados para o universo de empreendedores do Brasil. Todavia, como a quantidade de respondentes foi grande, é possível fazer as análises estatísticas apropriadas e cria-se a possibilidade futura de replicação da pesquisa em outras amostras.

Essa impossibilidade de generalização para a população de empreendedores do Brasil torna-se ainda mais evidente ao analisar-se que o gênero e o grau de escolaridade da amostra pesquisada não correspondem ao padrão médio dos empreendedores brasileiros apontados por outras pesquisas, como por exemplo a de Greco et al (2013).

O fato de utilizar pessoas que estavam registradas em um portal que oferecia informações sobre planejamento também pode ser um limitante para essas pesquisas. Essas pessoas tendem a estar mais propícias a planejar, uma vez que já foram atrás dessa informação. Isso precisa ser verificado replicando futuramente essa pesquisa em uma amostra diferente de pessoas.

Por ter sido proposta a utilização de um questionário criado pelo pesquisador para esta tese, embora tenham sido feitos pré-testes, o mesmo ainda apresentou alguns pontos para melhorias futuras. O principal deles ocorreu devido à falta de entendimento dos respondentes sobre a sua idade. A análise dos dados mostrou que muitos indivíduos responderam com a idade da empresa, o que impossibilitou a realização de testes da influência da idade nas ações dos empreendedores e de caracterizar a amostra a partir dessa informação. Em um futuro estudo, essa questão precisa ficar mais clara neste questionário.

Outra limitação da pesquisa refere-se ao fato de solicitar ao respondente que lembre-se do momento de criação da empresa para responder às perguntas do questionário sobre sua ação empreendedora. Esse ato pode contar com os efeitos do tempo sobre a memória do indivíduo e pode fazer com que algumas respostas não representem exatamente seu comportamento.

Também não foi possível comprovar se o respondente realmente participou do processo empreendedor em algum momento da sua vida, como era solicitado a todos que responderam ao questionário. Dessa forma, algumas respostas podem ter sido de pessoas que não deveriam fazer parte da amostra pesquisada. 
O modelo apresentado também apontou alguns pontos de melhoria, como, por exemplo, a necessidade de exclusão de algumas variáveis que medem o constructo Comportamento do Empreendedor. Isso aponta que, em uma próxima pesquisa, as atividades realizadas pelo empreendedor precisam ser novamente analisadas e algumas delas podem ser agrupadas, a fim de aumentar a confiabilidade e a validade do instrumento de medição. Essa limitação já era esperada, especialmente pelo fato de ter sido criado um novo instrumento de pesquisa para o presente estudo.

Essas possibilidades de melhorias com essa medição ficam ainda mais evidentes no Subprocesso 2, que apresentou problemas nos testes de Confiabilidade e de Validade Convergente, possibilidades essas, no entanto, que não impediram que o modelo provasse que de maneira geral o Comportamento do Empreendedor influencia no desempenho da empresa.

A medição do Desempenho da empresa também é um fator que apresentou problemas no modelo geral, devido ao seu baixo grau de explicação com as variáveis utilizadas (evidenciado pelo valor baixo do $\mathrm{R}^{2}$ ). Esse problema pode ter ocorrido pela tentativa de medir o desempenho de maneira generalizada, sem levar em conta características diferentes de desempenho para empresas de setores diferentes. 


\section{REFERÊNCIAS}

BAUM, Robert; FRESE, Michael; BARON, Robert; KATZ, Jerome. Entrepreneurship as an area of psychology study: An introduction. In: BAUM, Robert; FRESE Michael; BARON, Robert. The psychology of entrepreneurship. Mahwah:Erlbaum, p. 1-18, 2007.

BHAVE, Mahesh. A process model of entrepreneurial venture creation. Journal of Business Venturing. v.9, n.3, p. 223-242, 1994.

BARCLAY, Donald; HIGGINS, Christopher; THOMPSON, Ronald. The partial least squares (PLS) approach to causal modeling: Personal computer adoption and use as an illustration. Technology studies, v. 2, n. 2, p. 285-309, 1995 apud HAIR, Joseph; HULT, G.Tomas.M.; RINGLE, Christian M.; SARSTEDT, Makro. A Primer on Partial Least Squares Structural Equation Modeling (PLS-SEM). Thousand Oaks: Sage, 2013.

BIANCHI, Carmine; WINCH, Graham; GREY, Colin. The business plan as a learningoriented tool for small/medium snterprises: a business simulation approach. In: Proceedings of the 1998 International System Dynamics Society Conference, 1998.

BIDO, Diógenes. S. et al. Mensuração com Indicadores Formativos na Pesquisas em Administração de Empresas: como lidar com a multicolinariedade entre eles. Administração: Ensino e Pesquisa, v. 11, n. 2, p. 245-269, 2010.

BIRD, Barbara. Entrepreneurial Behavior. Glenview: Scott, Foresman and Company, 1989.

BIRD, Barbara; SCHJOEDT, Leon. Entrepreneurial behavior: Its nature, scope, recent research, and agenda for future research. In: CARSRUD, Alan; BRÄNNBACK, Malin, Understanding the entrepreneurial mind: Opening the black box. New York: Springer Science \& Business Media, p.327-358, 2009.

BIRD, Barbara; SCHJOEDT, Leon; BAUM, Robert. Editor's Introduction. Entrepreneurs' Behavior: Elucidation and Measurement. Entrepreneurship Theory and Practice. v.36, n.5, p. 889-913, 2012.

BRUSH, Candia; VANDERWERF, Pieter. A comparison of methods and sources for obtaining estimates of new venture performance. Journal of Business Venturing, v. 7 , p.157-170, 1992.

BRUYAT, Christian; JULIEN, Pierre-André. Defining the field of research in entrepreneurship. Journal of Business Venturing, v.16, p. 165-180, 2000. 
BYGRAVE, William. The Entrepreneurial Process. In BYGRAVE, William; ZACHARAKIS, Andrew. The portable MBA in entrepreneurship. Boston: John Wiley \& Sons, 2004.

BYGRAVE, William; ZACHARAKIS, Andrew. The portable MBA in entrepreneurship $4^{\text {th }}$ edition. Boston: John Wiley \& Sons, 2010.

CAMPOS, Eliane Vargas de. As características do comportamento empreendedor. In: SEMINÁRIO DE PESQUISA - UNIVERSIDADE LUTERANA DO BRASIL, $X$, 2007, Guaíba. Anais eletrônicos... Disponível em: 〈http://guaiba.ulbra.tche.br/pesquisa/2007/artigos/administracao/302.pdf >. Acesso em: 03/02/2013.

CHANDLER, Gaylen; HANKS, Steven. Measuring the performance of emerging businesses: a validation study. Journal of business venturing, v.8, p. 391-408, 1993.

CHATTOPADHYAY, Rachana; GHOSH, Anjali. Predicting Entrepreneurial success: A socio-psychological study. Journal of entrepreneurship, v.11, n.1, p. 21-31, 2002.

COHEN, Jacob. A power primer. Psychological bulletin, v. 112, n. 1, p. 155, 1992. apud HAIR, Joseph; HULT, G.Tomas.M.; RINGLE, Christian M.; SARSTEDT, Makro. A Primer on Partial Least Squares Structural Equation Modeling (PLSSEM). Thousand Oaks: Sage, 2013.

COOPER, Arnold; ARTZ, Kendall. Determinants of satisfaction for entrepreneurs. Journal of Business Venturing, v.10, p. 439-457, 1995.

COOPER, Donald; SCHINDLER, Pamela. Métodos de pesquisa em administração. 10.ed. Porto Alegre: Bookman, 2011.

DEW, Nicholas; READ, Stuart; SARASVATHY, Saras; WILTBANK, Robert. Outlines of a behavioral theory of the entrepreneurial firm. Journal of Economic Behavior \& Organization v. 66, n. 1, p. 37-59, 2008.

DORNELAS, José Carlos Assis. Empreendedorismo: Transformando ideias em negócios. 3.ed. Rio de Janeiro: Elsevier, 2008.

ENDRES, Anthony, WOODS, Christine. Modern Theories of Entrepreneurial Behavior: A Comparison and Appraisal. Small Business Economics, v. 26, p. 189-202, 2006.

FARIAS, Salomão Alencar; SANTOS, Rubens da Costa. Modelagem de equações estruturais e satisfação do consumidor: uma investigação teórica e prática. Revista de Administração Conteporânea, v.4, n.3, 2000. 
FILLION, Louis Jaques.'From Entrepreneurship to Entreprenology, Entrepreneurship: The Engine of Global Economic Development In:, 42nd World Conference, International Council for Small Business, San Francisco. Conference Proceedings, 1997.

FILLION, Louis Jaques. Empreendedorismo: empreendedores e proprietários-gerentes de pequenos negócios. Revista de Administração, v.34, n.2, p. 05-28, 1999.

FISHER, Greg. Effectuation, Causation, and Bricolage: A behavioral comparison of emerging theories in entrepreneurship research. Entrepreneurship Theory and Practice. v. 35, n.5, p. 1019-1051, 2012.

FRESE, Michael; VAN GELDEREN, Marco; OMBACH, Mikael. How to plan as a small scale business owner: Psychological process characteristics of action strategies and success. Journal of small business management. v.38, n.2, p. 1-18, 2000.

GARTNER, William. A conceptual framework for describing the phenomenon of new venture creation. Academy of Management Review, v.10, n.4, p.696-706, 1985.

GARTNER, William; CARTER, Nancy; REYNOLDS, Paul. Entrepreneurial Behavior: Firm Organizing Processes. In: ACS, Zoltan; AUDRETSCH, David. Handbook of Entrepreneurship Research: An Interdisciplinary Survey and Introduction $2^{\text {nd }}$ ed. New York: Springer, p. 99-127, 2010.

GRECO, Simara Maria de Souza Silveira et al. Empreendedorismo no Brasil: 2011. Curitiba: IBQP, 2011.

GRECO, Simara Maria de Souza Silveira et al. Empreendedorismo no Brasil: 2013. Relatório Executivo Curitiba: IBQP, 2013.

HAIR, Joseph; BLACK, Bill; BABIN, Barry; ANDERSON, Rolph; TATHAM, Ronald. Multivariate data analysis. New Jersey: Prentice Hall, 1998.

HAIR, Joseph; BABIN, Barry; MONEY, Arthur; SAMUEL, Phillip. Fundamentos de Métodos de Pesquisa em Administração. Porto Alegre: Bookman, 2005.

HAIR, Joseph; HULT, G.Tomas.M.; RINGLE, Christian M.; SARSTEDT, Makro. A Primer on Partial Least Squares Structural Equation Modeling (PLS-SEM). Thousand Oaks: Sage, 2013.

HARRINGTON, James. Aperfeiçoando processos empresariais. Tradução Luiz Liske. São Paulo: Makron Books, 1993. 
HISRICH, Robert; PETERS, Michael; SHEPHERED, Dean. Entrepreneurship. $6^{\text {th }}$. ed. New York: McGraw-Hill/Irwin, 2005.

HMIELESKI, Keith; CORBETT, Andrew. The contrasting interaction effects of improvisational behavior with entrepreneurial self-efficacy on new venture performance and entrepreneur work satisfaction. Journal of Business Venturing, v.23, p. 482-496, 2008.

HONIG, Benson; KARLSSON, Tomas. Institutional forces and the written business plan. Journal of Management. v. 30, n. 1, p. 29-48, 2004.

HULLAND, John. Use of partial least squares (PLS) in strategic management research: a review of four recent studies. Strategic management journal, v. 20, n. 2, p. 195-204, 1999 apud HAIR, Joseph; HULT, G.Tomas.M.; RINGLE, Christian M.; SARSTEDT, Makro. A Primer on Partial Least Squares Structural Equation Modeling (PLS-SEM). Thousand Oaks: Sage, 2013.

KLEM, Laura. Path analysis. In: GRIMM, Laurence; YARNOLD, Paul. Reading and understanding multivariate statistics. Washington: American Psychological Association, 1995.

MALHOTRA, Naresh. Pesquisa de marketing: uma orientação aplicada. 3rd ed. Porto Alegre: Bookman, 2001.

MAN, Thomas; LAU, Theresa; SNAPE, Ed. Entrepreneurial Competencies and the Performance of Small and Medium Enterprises: An Investigation through a Framework of Competitiveness. Journal of Small Business \& Entrepreneurship, v.21, n.3, p. 257276, 2008.

MARIANO, Sandra; MAYER, Verônica. Empreendedorismo e inovação: criatividade e atitude empreendedora. Rio de Janeiro: Fundação CECIERJ, 2008.

MARUYAMA, Geoffrey. Basics of structural equation modeling. London: Sage Publications, 1998.

MATIAS, Márcia Athayde. Relação entre características empreendedoras e múltiplas inteligências: Um estudo com contadores de Minas Gerais, Tese de Doutorado na Universidade de São Paulo, 2010.

MCCLELLAND, David. The achieving society. Princeton: D. Van Nostrand, 1961.

MCCLELLAND, David. N-Achievment and entrepreneurship: a longitudinal study. Journal of Personality and Social Psychology, Washington, v.1, n.4, p. 392-396, 1965. 
MCCLELLAND, David. Characteristics of successful entrepreneurs. The Journal of Creative Behavior, Buffalo, v.21, n.3, p. 219-233, 1987.

MINER, John. A psychological typology and its relationship to entrepreneurial success, Entrepreneurship \& Regional Development: An International Journal, v.9, n.4, p.319-334, 1997.

MOORE, Carol. Understanding Entrepreneurial Behavior. Academy of Management best paper proceedings, Chicago, p.66-70, 1986.

MOROZ, Peter; HINDLE, Kevin. Entrepreneurship as a Process: Toward Harmonizing Multiple Perspectives. Entrepreneurship Theory and Practice. v.36, n.4, 2012.

MUELLER, Susan; VOLERY, Thierry; e VON SIEMENS, Björn. What Do Entrepreneurs Actually Do? An Observational Study of Entrepreneurs' Everyday Behavior in the Start-Up and Growth Stages. Entrepreneurship Theory and Practice, v.36, n. 5, p. 995-1017, 2012.

MURPHY, Gregory; TRAILER, Jeff; HILL, Robert. Measuring performance in entrepreneurship research. Journal of business research. v. 36, p. 15-23, 1996.

PREARO, Leandro. Os serviços públicos e o bem-estar subjetivo da população: Uma modelagem multigrupos baseada em mínimos quadrados parciais. São Paulo, 2013. Tese (Doutorado em Administração de empresas) - Programa de Pós-Graduação em Administração de Empresas, Faculdade de Economia, Administração e Contabilidade da Universidade de São Paulo.

RAVEN, John. The McClelland/McBer Competency Models In: Competence in the Learning Society. New York: Peter Lang, 2001.

RHONDA, Abrams. The successful business plan: secrets \& strategies. $4^{\text {th }}$.ed. Palo alto: The Planning Shop, 2003.

SANDBERG, William; HOFER, Charles. Improving new venture performance: The role of strategy, industry structure, and the entrepreneur. Journal of Business Venturing, v.2, p. 5-28, 1987.

SAHLMAN, William. How to write a great business plan. Harvard Business Review. (July-August), p. 97-108, 1997.

SAMPIERI, Roberto Hernández; COLLADO, C. H.; LUCIO, P. B.; MURAD, F. C.; GARCIA, A. G. Q. Metodologia de pesquisa. São Paulo: McGraw-Hill. 2006. 
SANTOS, Silvio Aparecido dos. A criação de Empresas Industriais - a figura do empreendedor e a influência da tecnologia no processo. São Paulo, 1983. Tese (Doutorado em Administração de empresas) - Programa de Pós-Graduação em Administração de Empresas, Faculdade de Economia, Administração e Contabilidade da Universidade de São Paulo.

SARASVATHY, Saras D., How do firms come to be? Towards a theory of the prefirm. Pittsburgh, 1998. Tese de doutorado - Carnegie Mellon University.

SARASVATHY, Saras D., Causation and effectuation: Toward a theoretical shift from economic inevitability to entrepreneurial contingency. Academy of Management Review, v. 26, n. 2, p. 243-263, 2001a.

SARASVATHY, Saras, D., What makes entrepreneurs entrepreneurial? Darden Business Publishing, 2001b. Disponível em < http://www.effectuation.org/paper/whatmakes-entrepreneurs-entrepreneurial > Acessado em 03/02/2012.

SARASVATHY, Saras D.; KOTHA, Suresh, Effectuation in the management of Knightian uncertainty: Evidence from the Realnetworks case. In: BUTLER, J., Research on Management and Entrepreneurship: Vol. 1 Greenwichh, CT:IAP Inc, 2001 Disponível em < http://effectuation.org/paper/effectuation-managementknightian-uncertainty-evidence-realnetworks-case > Acessado em 03/02/2012.

SARASVATHY, Saras D. Effectuation: elements of entrepreneurial expertise. Massachussets: Edward Elgar Publishing Inc, 2006.

SBICCA, Adriana.; FERNANDES, André. L. (2005). A racionalidade em Simon e a firma evolucionária deNelson e Winter: Uma visão sistêmica. Encontro Nacional de Economistas - ANPEC, 2005.

SCHILIT, Keith. How to write a winning business plan. Business Horizons. V.30, n. 5, p. 13-22, 1987.

SCHUMPETER, J. A. Teoria do desenvolvimento econômico: uma investigação sobre lucros, capital, crédito, juro e o ciclo econômico. São Paulo: Nova Cultura, 1982.

SHANE, Scott. A general theory of entrepreneurship: The individual-opportunity nexus. Cheltenham.: Edward Elgar Publishing, 2003.

TIMMONS, Jeffry; SMOLLEN, Leonard.; DINGEE, Alexander. New venture creation: a guide to small business development. Illinois: Homewood, 1977.

UNITED NATIONS CONFERENCE ON TRADE AND DEVELOPMENT DIVISION ON INVESTMENT AND ENTERPRISE (UNCTAD) Empretec Annual Report, 2011. 
Disponível em $\quad<\quad$ http://www.unctadxi.org/Sections/DITE/empretec /docs/Empretec_Annual_Report_2011.pdf $>$ Acessado em 06/05/2013.

UNITED NATIONS CONFERENCE ON TRADE AND DEVELOPMENT DIVISION ON INVESTMENT AND ENTERPRISE (UNCTAD). Empretec Programme: The Entrepreneur's Guide, 2013. Disponível em http://www.unctadxi.org/Sections/DITE lempretec/docs/UN\%20Ref\%20Guide\%20Complete.pdf > Acessado em 06/05/2013.

VENTURI, James Luiz. Estudo das características empreendedoras dos proprietários de restaurantes na cidade de Itapema, conforme abordagem de David McClelland. 2003. Dissertação (Mestrado em Turismo e Hotelaria). Universidade Vale do Itajaí. Balneário Camboriú, 2003.

WALKER, Elizabeth; BROWN, Alan. What success factors are important to small business owners? International small business journal, v.22, n.6 p. 577-594, 2004.

WITT, Peter. Entrepreneurs' networks and the success of start-ups, Entrepreneurship \& Regional Development: An International Journal, v.16, n.5, p.391-412, 2004.

WIKLUND, Johan; SHEPHERD, Dean. Knowledge-based resources, entrepreneurial orientation, and the performance of small and medium-sized businesses, Strategic Management Journal, v.24, p. 1307-1314, 2003.

WIKLUND, Johan; SHEPHERD, Dean. Entrepreneurial orientation and small business performance: a configurational approach, Journal of Business Venturing, v. 20, n.1, p. 71-91, 2005. 


\section{APÊNDICES}

APÊNDICE 1 - INSTRUMENTO PARA COLETA DE DADOS APÊNDICE 2 - DETALHAMENTO DO PROCESSO EMPREENDEDOR APÊNDICE 3 - TESTE DE PERFIL EMPREENDEDOR (MCCLELLAND) 


\subsection{APÊNDICE 1 - INSTRUMENTO PARA COLETA DE DADOS}

Prezado(a),

Esta pesquisa tem por objetivo estudar o comportamento do empreendedor no processo de criação do seu negócio. Isto implica em conhecer o perfil dos empreendedores que criaram suas empresas, bem como seu comportamento (como agiu) na condução das várias etapas do processo de criação.

Solicitamos a sua valiosa contribuição para responder ao questionário desta pesquisa disponível abaixo.

Ao responder essa pesquisa e informar o seu e-mail você receberá acesso gratuito ao curso online "Como calcular o valor da sua empresa" e uma síntese dos resultados compilados desta pesquisa quando ela estiver concluída. Em nenhum momento informações individuais serão divulgadas.

Pedimos que só responda esta pesquisa caso você já tenha conduzido/liderado em algum momento de sua vida o processo de criação de uma empresa. A estimativa de tempo a ser gasto para responder a pesquisa é de 12 a 15 minutos, no máximo.

Esta pesquisa é parte de uma tese de doutorado que está sendo elaborada na FEA-USP pelo Eduardo Vilas Boas, gerente do Portal Plano de Negócios.

\section{Seção 1 - Comportamento do Empreendedor}

\section{INSTRUÇÕES PARA RESPONDER AS QUESTÕES}

Para responder as questões desta pesquisa procure se lembrar das etapas do processo de criação da sua empresa (ou de uma das suas empresas, caso já tenha criado mais de uma empresa). Considere o processo de criação da empresa como sendo o período compreendido desde que você teve a ideia do negócio até três anos após o início das operações da empresa. 
Leia atentamente as afirmações abaixo e classifique-as de acordo com o seu nível de concordância, sendo 0 se Discordar Totalmente e 10 se Concordar Totalmente.

Assim, quanto maior a nota, maior é sua concordância em relação à afirmação e quanto menor a nota, menor é sua concordância.

Por favor, responda a todas as afirmativas.

\section{Explicação do sub-processo 1 - Busca de ideias, seleção da oportunidade e definição do conceito de negócio}

Essa é a primeira etapa pela qual um empreendedor passa antes de criar um novo negócio. Essa etapa começa com a ideia inicial para a empresa, avança pela seleção da oportunidade e pela definição de como será o conceito do negócio.

\begin{tabular}{|c|c|c|c|c|c|c|c|c|c|c|c|c|}
\hline \multicolumn{13}{|c|}{ AFIRMAÇÕES } \\
\hline 1 & \multicolumn{12}{|c|}{$\begin{array}{l}\text { Para a minha ideia inicial foram mais importantes o que eu sabia fazer e quem eu conhecia } \\
\text { do que o mercado }\end{array}$} \\
\hline $\begin{array}{l}\text { Discorda } \\
\text { Totalmente }\end{array}$ & 0 & 1 & 2 & 3 & 4 & 5 & 6 & 7 & 8 & 9 & 10 & $\begin{array}{l}\text { Concorda } \\
\text { Totalmente }\end{array}$ \\
\hline 2 & \multicolumn{12}{|c|}{ Eu não tinha um conceito inicial de negócio } \\
\hline $\begin{array}{l}\text { Discorda } \\
\text { Totalmente }\end{array}$ & 0 & 1 & 2 & 3 & 4 & 5 & 6 & 7 & 8 & 9 & 10 & $\begin{array}{l}\text { Concorda } \\
\text { Totalmente }\end{array}$ \\
\hline 3 & \multicolumn{12}{|c|}{$\begin{array}{c}\text { O conceito do negócio foi construído pouco a pouco em função de adaptações para atender a } \\
\text { possíveis parceiros e clientes }\end{array}$} \\
\hline $\begin{array}{l}\text { Discorda } \\
\text { Totalmente }\end{array}$ & 0 & 1 & 2 & 3 & 4 & 5 & 6 & 7 & 8 & 9 & 10 & $\begin{array}{l}\text { Concorda } \\
\text { Totalmente }\end{array}$ \\
\hline 4 & \multicolumn{12}{|c|}{ Busquei informações antes de iniciar a empresa sobre o mercado no qual eu poderia atuar } \\
\hline $\begin{array}{l}\text { Discorda } \\
\text { Totalmente }\end{array}$ & 0 & 1 & 2 & 3 & 4 & 5 & 6 & 7 & 8 & 9 & 10 & $\begin{array}{l}\text { Concorda } \\
\text { Totalmente }\end{array}$ \\
\hline 5 & \multicolumn{12}{|c|}{$\begin{array}{l}\text { Busquei informações antecipadas sobre quais seriam meus concorrentes e com isso refinei } \\
\text { meu conceito de negócio }\end{array}$} \\
\hline $\begin{array}{l}\text { Discorda } \\
\text { Totalmente }\end{array}$ & 0 & 1 & 2 & 3 & 4 & 5 & 6 & 7 & 8 & 9 & 10 & $\begin{array}{l}\text { Concorda } \\
\text { Totalmente }\end{array}$ \\
\hline 6 & \multicolumn{12}{|c|}{$\begin{array}{l}\text { Identifiquei nichos de mercado não explorados e, a partir deles, defini quem seriam meus } \\
\text { principais clientes e quais produtos/serviços eu deveria oferecer }\end{array}$} \\
\hline $\begin{array}{l}\text { Discorda } \\
\text { Totalmente }\end{array}$ & 0 & 1 & 2 & 3 & 4 & 5 & 6 & 7 & 8 & 9 & 10 & $\begin{array}{l}\text { Concorda } \\
\text { Totalmente }\end{array}$ \\
\hline 7 & \multicolumn{12}{|c|}{ Fiz um plano de negócios completo antes mesmo de começar a minha empresa } \\
\hline $\begin{array}{l}\text { Discorda } \\
\text { Totalmente }\end{array}$ & 0 & 1 & 2 & 3 & 4 & 5 & 6 & 7 & 8 & 9 & 10 & $\begin{array}{l}\text { Concorda } \\
\text { Totalmente }\end{array}$ \\
\hline 8 & \multicolumn{12}{|c|}{ Fiz cursos e busquei conhecimentos que me dariam base para ser um empreendedor melhor } \\
\hline $\begin{array}{l}\text { Discorda } \\
\text { Totalmente }\end{array}$ & 0 & 1 & 2 & 3 & 4 & 5 & 6 & 7 & 8 & 9 & 10 & $\begin{array}{l}\text { Concorda } \\
\text { Totalmente }\end{array}$ \\
\hline
\end{tabular}


Explicação do sub-processo 2 - Comprometer recursos próprios e/ou de terceiros

Essa é a segunda etapa do processo de criação de uma empresa. Ela tem início no momento em que o empreendedor decide explorar o conceito de negócio criado. Para isso, ele resolve comprometer seus recursos (dinheiro, tempo, outros) e/ou de terceiros.

\begin{tabular}{|c|c|c|c|c|c|c|c|c|c|c|c|c|}
\hline 9 & \multicolumn{12}{|c|}{$\begin{array}{l}\text { Quando decidi abrir a minha empresa, deixei todas as minhas outras atividades para me } \\
\text { dedicar exclusivamente a isso }\end{array}$} \\
\hline $\begin{array}{l}\text { Discorda } \\
\text { Totalmente }\end{array}$ & 0 & 1 & 2 & 3 & 4 & 5 & 6 & 7 & 8 & 9 & 10 & $\begin{array}{l}\text { Concorda } \\
\text { Totalmente }\end{array}$ \\
\hline 10 & \multicolumn{12}{|c|}{$\begin{array}{l}\text { Meu primeiro produto/serviço sofreu grandes influências das opiniões de futuros clientes e } \\
\text { fornecedores durante o seu desenvolvimento }\end{array}$} \\
\hline $\begin{array}{l}\text { Discorda } \\
\text { Totalmente }\end{array}$ & 0 & 1 & 2 & 3 & 4 & 5 & 6 & 7 & 8 & 9 & 10 & $\begin{array}{l}\text { Concorda } \\
\text { Totalmente }\end{array}$ \\
\hline 11 & \multicolumn{12}{|c|}{$\begin{array}{l}\text { Fiz uma previsão de todas as necessidades de investimento e projeções de receita da futura } \\
\text { empresa }\end{array}$} \\
\hline $\begin{array}{l}\text { Discorda } \\
\text { Totalmente }\end{array}$ & 0 & 1 & 2 & 3 & 4 & 5 & 6 & 7 & 8 & 9 & 10 & $\begin{array}{l}\text { Concorda } \\
\text { Totalmente }\end{array}$ \\
\hline 12 & \multicolumn{12}{|c|}{$\begin{array}{c}\text { Eu sabia que o valor máximo a ser investido na empresa deveria ser o dinheiro que eu tinha } \\
\text { disponível, mesmo que isso significasse não seguir o melhor para a empresa }\end{array}$} \\
\hline $\begin{array}{l}\text { Discorda } \\
\text { Totalmente }\end{array}$ & 0 & 1 & 2 & 3 & 4 & 5 & 6 & 7 & 8 & 9 & 10 & $\begin{array}{l}\text { Concorda } \\
\text { Totalmente }\end{array}$ \\
\hline 13 & \multicolumn{12}{|c|}{ Economizei recursos por algum tempo até possuir o capital necessário para iniciar a empresa } \\
\hline $\begin{array}{l}\text { Discorda } \\
\text { Totalmente }\end{array}$ & 0 & 1 & 2 & 3 & 4 & 5 & 6 & 7 & 8 & 9 & 10 & $\begin{array}{l}\text { Concorda } \\
\text { Totalmente }\end{array}$ \\
\hline 14 & \multicolumn{12}{|c|}{$\begin{array}{l}\text { Aceitei todos os recursos de terceiros que poderiam me ajudar a implementar a empresa, } \\
\text { mesmo que as condições oferecidas não fossem as melhores }\end{array}$} \\
\hline $\begin{array}{l}\text { Discorda } \\
\text { Totalmente }\end{array}$ & 0 & 1 & 2 & 3 & 4 & 5 & 6 & 7 & 8 & 9 & 10 & $\begin{array}{l}\text { Concorda } \\
\text { Totalmente }\end{array}$ \\
\hline 15 & \multicolumn{12}{|c|}{ Só fiz sociedades com pessoas que tinham o perfil ideal que eu procurava } \\
\hline $\begin{array}{l}\text { Discorda } \\
\text { Totalmente }\end{array}$ & 0 & 1 & 2 & 3 & 4 & 5 & 6 & 7 & 8 & 9 & 10 & $\begin{array}{l}\text { Concorda } \\
\text { Totalmente }\end{array}$ \\
\hline
\end{tabular}

\section{Explicação do sub-processo 3 - Criação da empresa (formalização legal)}

Essa etapa do processo empreendedor corresponde ao momento em que o empreendedor decide formalizar sua empresa, principalmente fazer registros legais necessários para sua operação.

\begin{tabular}{|c|l|l|l|l|l|l|l|l|l|l|l|l|}
\hline 16 & \multicolumn{6}{|c|}{ Encaminhei o processo de patenteamento e/ou direitos autorais dos meus produtos/serviços } \\
\hline $\begin{array}{l}\text { Discorda } \\
\text { Totalmente }\end{array}$ & 0 & 1 & 2 & 3 & 4 & 5 & 6 & 7 & 8 & 9 & 10 & $\begin{array}{l}\text { Concorda } \\
\text { Totalmente }\end{array}$ \\
\hline
\end{tabular}

Comecei a empresa com a estrutura mínima possível, sabendo que depois eu poderia melhorá-la

\begin{tabular}{|l|l|l|l|l|l|l|l|l|l|l|l|l|}
\hline $\begin{array}{l}\text { Discorda } \\
\text { Totalmente }\end{array}$ & 0 & 1 & 2 & 3 & 4 & 5 & 6 & 7 & 8 & 9 & 10 & $\begin{array}{l}\text { Concorda } \\
\text { Totalmente }\end{array}$ \\
\hline
\end{tabular}

18

Criei uma primeira versão comercializável do produto/serviço e já a coloquei no mercado, mesmo sabendo que essa não era a versão ideal

\begin{tabular}{|l|l|l|l|l|l|l|l|l|l|l|l|l|}
\hline $\begin{array}{l}\text { Discorda } \\
\text { Totalmente }\end{array}$ & 0 & 1 & 2 & 3 & 4 & 5 & 6 & 7 & 8 & 9 & 10 & $\begin{array}{l}\text { Concorda } \\
\text { Totalmente }\end{array}$ \\
\hline
\end{tabular}

19

Busquei uma localização ideal para a minha empresa baseada nos benefícios que poderia oferecer

\begin{tabular}{|l|l|l|l|l|l|l|l|l|l|l|l|l|}
\hline $\begin{array}{l}\text { Discorda } \\
\text { Totalmente }\end{array}$ & 0 & 1 & 2 & 3 & 4 & 5 & 6 & 7 & 8 & 9 & 10 & $\begin{array}{l}\text { Concorda } \\
\text { Totalmente }\end{array}$ \\
\hline
\end{tabular}

20 Pesquisei muito para definir o nome e a marca da empresa, inclusive me preocupei em saber se eles já eram usados por outras empresas 


\begin{tabular}{|c|c|c|c|c|c|c|c|c|c|c|c|c|}
\hline $\begin{array}{l}\text { Discorda } \\
\text { Totalmente }\end{array}$ & 0 & 1 & 2 & 3 & 4 & 5 & 6 & 7 & 8 & 9 & 10 & $\begin{array}{l}\text { Concorda } \\
\text { Totalmente }\end{array}$ \\
\hline 21 & \multicolumn{12}{|c|}{$\begin{array}{l}\text { Busquei conhecer e analisar a melhor forma jurídica para a empresa e suas pretensões } \\
\text { futuras. Conversei muito com o contador a respeito das possibilidades }\end{array}$} \\
\hline $\begin{array}{l}\text { Discorda } \\
\text { Totalmente }\end{array}$ & 0 & 1 & 2 & 3 & 4 & 5 & 6 & 7 & 8 & 9 & 10 & $\begin{array}{l}\text { Concorda } \\
\text { Totalmente }\end{array}$ \\
\hline \multicolumn{13}{|c|}{ Explicação do sub-processo 4 - Gerenciamento da empresa nos primeiros anos } \\
\hline 22 & \multicolumn{12}{|c|}{$\begin{array}{l}\text { A primeira venda da empresa aconteceu para um cliente que se enquadrava exatamente no } \\
\text { público-alvo que eu planejara }\end{array}$} \\
\hline $\begin{array}{l}\text { Discorda } \\
\text { Totalmente }\end{array}$ & 0 & 1 & 2 & 3 & 4 & 5 & 6 & 7 & 8 & 9 & 10 & $\begin{array}{l}\text { Concorda } \\
\text { Totalmente }\end{array}$ \\
\hline 23 & \multicolumn{12}{|c|}{$\begin{array}{l}\text { As primeiras ações de divulgação da empresa foram feitas boca a boca por pessoas do meu } \\
\text { relacionamento }\end{array}$} \\
\hline $\begin{array}{l}\text { Discorda } \\
\text { Totalmente }\end{array}$ & 0 & 1 & 2 & 3 & 4 & 5 & 6 & 7 & 8 & 9 & 10 & $\begin{array}{l}\text { Concorda } \\
\text { Totalmente }\end{array}$ \\
\hline 24 & \multicolumn{12}{|c|}{$\begin{array}{l}\text { Contratei meu primeiro empregado mais pela confiança que eu tinha na pessoa e na } \\
\text { possibilidade de pagar seu salário. Isso foi menos importante do que ter o perfil ideal }\end{array}$} \\
\hline $\begin{array}{l}\text { Discorda } \\
\text { Totalmente }\end{array}$ & 0 & 1 & 2 & 3 & 4 & 5 & 6 & 7 & 8 & 9 & 10 & $\begin{array}{l}\text { Concorda } \\
\text { Totalmente }\end{array}$ \\
\hline 25 & \multicolumn{12}{|c|}{$\begin{array}{l}\text { Acompanhava rotineiramente as finanças da empresa para ter certeza de que tudo seguia } \\
\text { como eu havia planejado }\end{array}$} \\
\hline $\begin{array}{l}\text { Discorda } \\
\text { Totalmente }\end{array}$ & 0 & 1 & 2 & 3 & 4 & 5 & 6 & 7 & 8 & 9 & 10 & $\begin{array}{l}\text { Concorda } \\
\text { Totalmente }\end{array}$ \\
\hline 26 & \multicolumn{12}{|c|}{$\begin{array}{l}\text { Procuro assumir alguns riscos ao definir as ações/projetos/iniciativas da empresa, pois assim } \\
\text { posso aproveitar mais oportunidades }\end{array}$} \\
\hline $\begin{array}{l}\text { Discorda } \\
\text { Totalmente }\end{array}$ & 0 & 1 & 2 & 3 & 4 & 5 & 6 & 7 & 8 & 9 & 10 & $\begin{array}{l}\text { Concorda } \\
\text { Totalmente }\end{array}$ \\
\hline
\end{tabular}




\section{Seção 2 - Perfil Empreendedor}

Esta avaliação das características comportamentais empreendedoras é realizada com base no estudo desenvolvido por David McClelland, pesquisador de Harvard, que se especializou em comportamento empreendedor.

1 - Leia cuidadosamente cada afirmação e decida qual melhor se aplica a você (considere como você é hoje, e não como gostaria de ser).

2 - Algumas afirmações podem ser parecidas, mas nenhuma é exatamente igual.

3 - Leia atentamente todas as questões.

4 - Se responder todas as questões dessa pesquisa você receberá o relatório com o seu perfil empreendedor em seu e-mail.

1 - Executo o que precisa ser feito sem medir esforços.

\begin{tabular}{|l|l|}
\hline & Nunca \\
\hline & Raras vezes \\
\hline & Algumas vezes \\
\hline & Usualmente \\
\hline & Sempre \\
\hline
\end{tabular}

2 - Quando encontro um problema difícil não desisto, mesmo que leve muito tempo para solucioná-lo.

\begin{tabular}{|l|l|}
\hline & Nunca \\
\hline & Raras vezes \\
\hline & Algumas vezes \\
\hline & Usualmente \\
\hline & Sempre \\
\hline
\end{tabular}

3 - Termino meu trabalho a tempo.

\begin{tabular}{|l|l|}
\hline & Nunca \\
\hline & Raras vezes \\
\hline & Algumas vezes \\
\hline & Usualmente \\
\hline & Sempre \\
\hline
\end{tabular}


4 - Aborreço-me quando as coisas não são feitas devidamente.

\begin{tabular}{|l|l|}
\hline & Nunca \\
\hline & Raras vezes \\
\hline & Algumas vezes \\
\hline & Usualmente \\
\hline & Sempre \\
\hline
\end{tabular}

5 - Prefiro situações em que posso controlar ao máximo o resultado final.

\begin{tabular}{|l|l|}
\hline & Nunca \\
\hline & Raras vezes \\
\hline & Algumas vezes \\
\hline & Usualmente \\
\hline & Sempre \\
\hline
\end{tabular}

6 - Gosto de pensar nas consequências futuras das minhas ações.

\begin{tabular}{|l|l|}
\hline & Nunca \\
\hline & Raras vezes \\
\hline & Algumas vezes \\
\hline & Usualmente \\
\hline & Sempre \\
\hline
\end{tabular}

7 - Quando começo uma tarefa ou projeto novo, coleto todas as informações possíveis antes de dar prosseguimento a ele.

\begin{tabular}{|l|l|}
\hline & Nunca \\
\hline & Raras vezes \\
\hline & Algumas vezes \\
\hline & Usualmente \\
\hline & Sempre \\
\hline
\end{tabular}

8 - Planejo um projeto grande dividindo-o em tarefas mais simples.

\begin{tabular}{|l|l|}
\hline & Nunca \\
\hline & Raras vezes \\
\hline & Algumas vezes \\
\hline & Usualmente \\
\hline & Sempre \\
\hline
\end{tabular}


9 - Consigo que os outros apoiem minhas propostas.

\begin{tabular}{|l|l|}
\hline & Nunca \\
\hline & Raras vezes \\
\hline & Algumas vezes \\
\hline & Usualmente \\
\hline & Sempre \\
\hline
\end{tabular}

10 - Tenho confiança que posso ser bem-sucedido em qualquer atividade que me proponha executar.

\begin{tabular}{|l|l|}
\hline & Nunca \\
\hline & Raras vezes \\
\hline & Algumas vezes \\
\hline & Usualmente \\
\hline & Sempre \\
\hline
\end{tabular}

11 - Não importa com quem fale, sempre escuto atentamente.

\begin{tabular}{|l|l|}
\hline & Nunca \\
\hline & Raras vezes \\
\hline & Algumas vezes \\
\hline & Usualmente \\
\hline & Sempre \\
\hline
\end{tabular}

12 - Faço as coisas que devem ser feitas sem que os outros tenham que me pedir.

\begin{tabular}{|l|l|}
\hline & Nunca \\
\hline & Raras vezes \\
\hline & Algumas vezes \\
\hline & Usualmente \\
\hline & Sempre \\
\hline
\end{tabular}

13 - Insisto várias vezes até conseguir que as outras pessoas façam o que desejo.

\begin{tabular}{|l|l|}
\hline & Nunca \\
\hline & Raras vezes \\
\hline & Algumas vezes \\
\hline & Usualmente \\
\hline & Sempre \\
\hline
\end{tabular}


14 - Cumpro as promessas que faço.

\begin{tabular}{|l|l|}
\hline & Nunca \\
\hline & Raras vezes \\
\hline & Algumas vezes \\
\hline & Usualmente \\
\hline & Sempre \\
\hline
\end{tabular}

15 - Meu rendimento no trabalho é superior ao das outras pessoas com quem trabalho.

\begin{tabular}{|l|l|}
\hline & Nunca \\
\hline & Raras vezes \\
\hline & Algumas vezes \\
\hline & Usualmente \\
\hline & Sempre \\
\hline
\end{tabular}

16 - Envolvo-me com algo novo só depois de ter feito todo o possível para assegurar o seu êxito.

\begin{tabular}{|l|l|}
\hline & Nunca \\
\hline & Raras vezes \\
\hline & Algumas vezes \\
\hline & Usualmente \\
\hline & Sempre \\
\hline
\end{tabular}

17 - Acho uma perda de tempo me preocupar com o que farei da minha vida no futuro.

\begin{tabular}{|l|l|}
\hline & Nunca \\
\hline & Raras vezes \\
\hline & Algumas vezes \\
\hline & Usualmente \\
\hline & Sempre \\
\hline
\end{tabular}

18 - Procuro conselhos das pessoas que são especialistas no ramo em que estou atuando.

\begin{tabular}{|l|l|}
\hline & Nunca \\
\hline & Raras vezes \\
\hline & Algumas vezes \\
\hline & Usualmente \\
\hline & Sempre \\
\hline
\end{tabular}


19 - Considero cuidadosamente as vantagens e desvantagens de diferentes alternativas antes de realizar uma tarefa.

\begin{tabular}{|l|l|}
\hline & Nunca \\
\hline & Raras vezes \\
\hline & Algumas vezes \\
\hline & Usualmente \\
\hline & Sempre \\
\hline
\end{tabular}

20 - Não perco muito tempo pensando em como posso influenciar as outras pessoas.

\begin{tabular}{|l|l|}
\hline & Nunca \\
\hline & Raras vezes \\
\hline & Algumas vezes \\
\hline & Usualmente \\
\hline & Sempre \\
\hline
\end{tabular}

21. Mudo a maneira de pensar se outros discordam energicamente dos meus pontos de vista

\begin{tabular}{|l|l|}
\hline & Nunca \\
\hline & Raras vezes \\
\hline & Algumas vezes \\
\hline & Usualmente \\
\hline & Sempre \\
\hline
\end{tabular}

22 - Aborreço-me quando não consigo o que quero.

\begin{tabular}{|l|l|}
\hline & Nunca \\
\hline & Raras vezes \\
\hline & Algumas vezes \\
\hline & Usualmente \\
\hline & Sempre \\
\hline
\end{tabular}

23 - Gosto de assumir desafios e explorar novas oportunidades.

\begin{tabular}{|l|l|}
\hline & Nunca \\
\hline & Raras vezes \\
\hline & Algumas vezes \\
\hline & Usualmente \\
\hline & Sempre \\
\hline
\end{tabular}


24 - Quando algo atrapalha o que eu estou tentando fazer, persisto em minha tarefa.

\begin{tabular}{|l|l|}
\hline & Nunca \\
\hline & Raras vezes \\
\hline & Algumas vezes \\
\hline & Usualmente \\
\hline & Sempre \\
\hline
\end{tabular}

25 - Se necessário, não me importo de fazer o trabalho dos outros para cumprir um prazo de entrega.

\begin{tabular}{|l|l|}
\hline & Nunca \\
\hline & Raras vezes \\
\hline & Algumas vezes \\
\hline & Usualmente \\
\hline & Sempre \\
\hline
\end{tabular}

26 - Aborreço-me quando perco tempo.

\begin{tabular}{|l|l|}
\hline & Nunca \\
\hline & Raras vezes \\
\hline & Algumas vezes \\
\hline & Usualmente \\
\hline & Sempre \\
\hline
\end{tabular}

27 - Avalio minhas possibilidades de êxito ou fracasso antes de começar a atuar.

\begin{tabular}{|l|l|}
\hline & Nunca \\
\hline & Raras vezes \\
\hline & Algumas vezes \\
\hline & Usualmente \\
\hline & Sempre \\
\hline
\end{tabular}

28 - Quanto mais específicas forem minhas expectativas em relação ao que quero obter na vida, maiores serão minhas possibilidades de êxito.

\begin{tabular}{|l|l|}
\hline & Nunca \\
\hline & Raras vezes \\
\hline & Algumas vezes \\
\hline & Usualmente \\
\hline & Sempre \\
\hline
\end{tabular}


29 - Tomo decisões rapidamente, sem perder tempo com busca de informações.

\begin{tabular}{|l|l|}
\hline & Nunca \\
\hline & Raras vezes \\
\hline & Algumas vezes \\
\hline & Usualmente \\
\hline & Sempre \\
\hline
\end{tabular}

30 - Levo em consideração todos os problemas que podem surgir e antecipo as possíveis soluções caso eles ocorram.

\begin{tabular}{|l|l|}
\hline & Nunca \\
\hline & Raras vezes \\
\hline & Algumas vezes \\
\hline & Usualmente \\
\hline & Sempre \\
\hline
\end{tabular}

31 - Conto com o apoio de pessoas influentes que conheço para alcançar minhas metas.

\begin{tabular}{|l|l|}
\hline & Nunca \\
\hline & Raras vezes \\
\hline & Algumas vezes \\
\hline & Usualmente \\
\hline & Sempre \\
\hline
\end{tabular}

32 - Quando estou executando algo difícil e desafiador, tenho confiança em meu sucesso.

\begin{tabular}{|l|l|}
\hline & Nunca \\
\hline & Raras vezes \\
\hline & Algumas vezes \\
\hline & Usualmente \\
\hline & Sempre \\
\hline
\end{tabular}

33 - Tive fracassos no passado

\begin{tabular}{|l|l|}
\hline & Nunca \\
\hline & Raras vezes \\
\hline & Algumas vezes \\
\hline & Usualmente \\
\hline & Sempre \\
\hline
\end{tabular}


34 - Prefiro executar tarefas que domino perfeitamente e com as quais me sinto seguro.

\begin{tabular}{|l|l|}
\hline & Nunca \\
\hline & Raras vezes \\
\hline & Algumas vezes \\
\hline & Usualmente \\
\hline & Sempre \\
\hline
\end{tabular}

35 - Quando me deparo com sérias dificuldades, rapidamente passo para outras atividades.

\begin{tabular}{|l|l|}
\hline & Nunca \\
\hline & Raras vezes \\
\hline & Algumas vezes \\
\hline & Usualmente \\
\hline & Sempre \\
\hline
\end{tabular}

36 - Quando estou fazendo um trabalho para outra pessoa, me esforço de forma especial, para que fique satisfeita com o trabalho.

\begin{tabular}{|l|l|}
\hline & Nunca \\
\hline & Raras vezes \\
\hline & Algumas vezes \\
\hline & Usualmente \\
\hline & Sempre \\
\hline
\end{tabular}

37 - Nunca fico totalmente satisfeito com a forma como são feitas as coisas; sempre considero que há uma maneira melhor de fazê-las.

\begin{tabular}{|l|l|}
\hline & Nunca \\
\hline & Raras vezes \\
\hline & Algumas vezes \\
\hline & Usualmente \\
\hline & Sempre \\
\hline
\end{tabular}

38 - Executo tarefas arriscadas.

\begin{tabular}{|l|l|}
\hline & Nunca \\
\hline & Raras vezes \\
\hline & Algumas vezes \\
\hline & Usualmente \\
\hline & Sempre \\
\hline
\end{tabular}


39 - Conto com um plano de vida claro e objetivo.

\begin{tabular}{|l|l|}
\hline & Nunca \\
\hline & Raras vezes \\
\hline & Algumas vezes \\
\hline & Usualmente \\
\hline & Sempre \\
\hline
\end{tabular}

40 - Quando executo um projeto para alguém, faço muitas perguntas para assegurar-me de que entendi o que quer.

\begin{tabular}{|l|l|}
\hline & Nunca \\
\hline & Raras vezes \\
\hline & Algumas vezes \\
\hline & Usualmente \\
\hline & Sempre \\
\hline
\end{tabular}

41 - Enfrento os problemas na medida em que surgem, em vez de perder tempo antecipando-os.

\begin{tabular}{|l|l|}
\hline & Nunca \\
\hline & Raras vezes \\
\hline & Algumas vezes \\
\hline & Usualmente \\
\hline & Sempre \\
\hline
\end{tabular}

42 - Para alcançar minhas metas, procuro soluções que beneficiem todas as pessoas envolvidas em um problema.

\begin{tabular}{|l|l|}
\hline & Nunca \\
\hline & Raras vezes \\
\hline & Algumas vezes \\
\hline & Usualmente \\
\hline & Sempre \\
\hline
\end{tabular}

43 - O trabalho que realizo é excelente.

\begin{tabular}{|l|l|}
\hline & Nunca \\
\hline & Raras vezes \\
\hline & Algumas vezes \\
\hline & Usualmente \\
\hline & Sempre \\
\hline
\end{tabular}


44 - Em algumas ocasiões obtive vantagens de outras pessoas.

\begin{tabular}{|l|l|}
\hline & Nunca \\
\hline & Raras vezes \\
\hline & Algumas vezes \\
\hline & Usualmente \\
\hline & Sempre \\
\hline
\end{tabular}

45 - Aventuro-me a fazer coisas novas e diferentes das que fiz no passado.

\begin{tabular}{|l|l|}
\hline & Nunca \\
\hline & Raras vezes \\
\hline & Algumas vezes \\
\hline & Usualmente \\
\hline & Sempre \\
\hline
\end{tabular}

46 - Tenho diferentes maneiras de superar obstáculos que se apresentam para a obtenção de minhas metas.

\begin{tabular}{|l|l|}
\hline & Nunca \\
\hline & Raras vezes \\
\hline & Algumas vezes \\
\hline & Usualmente \\
\hline & Sempre \\
\hline
\end{tabular}

47 - Minha família e vida pessoal são mais importantes para mim do que as datas que determinei para entrega de trabalhos/projetos.

\begin{tabular}{|l|l|}
\hline & Nunca \\
\hline & Raras vezes \\
\hline & Algumas vezes \\
\hline & Usualmente \\
\hline & Sempre \\
\hline
\end{tabular}

48 - Encontro a maneira mais rápida de terminar os trabalhos, tanto em casa quanto no trabalho.

\begin{tabular}{|l|l|}
\hline & Nunca \\
\hline & Raras vezes \\
\hline & Algumas vezes \\
\hline & Usualmente \\
\hline & Sempre \\
\hline
\end{tabular}


49 - Faço coisas que as outras pessoas consideram arriscadas.

\begin{tabular}{|l|l|}
\hline & Nunca \\
\hline & Raras vezes \\
\hline & Algumas vezes \\
\hline & Usualmente \\
\hline & Sempre \\
\hline
\end{tabular}

50 - Preocupo-me tanto em alcançar minhas metas semanais quanto minhas metas anuais.

\begin{tabular}{|l|l|}
\hline & Nunca \\
\hline & Raras vezes \\
\hline & Algumas vezes \\
\hline & Usualmente \\
\hline & Sempre \\
\hline
\end{tabular}

51 - Conto com várias fontes de informação ao procurar ajuda para a execução de tarefas e projetos.

\begin{tabular}{|l|l|}
\hline & Nunca \\
\hline & Raras vezes \\
\hline & Algumas vezes \\
\hline & Usualmente \\
\hline & Sempre \\
\hline
\end{tabular}

52 - Se determinado método para enfrentar um problema não der certo, recorro a outro.

\begin{tabular}{|l|l|}
\hline & Nunca \\
\hline & Raras vezes \\
\hline & Algumas vezes \\
\hline & Usualmente \\
\hline & Sempre \\
\hline
\end{tabular}

53 - Posso conseguir que pessoas com firmes convicções e opiniões mudem seu modo de pensar.

\begin{tabular}{|l|l|}
\hline & Nunca \\
\hline & Raras vezes \\
\hline & Algumas vezes \\
\hline & Usualmente \\
\hline & Sempre \\
\hline
\end{tabular}


54 - Mantenho-me firme em minhas decisões, mesmo quando as outras pessoas se opõem energicamente.

\begin{tabular}{|l|l|}
\hline & Nunca \\
\hline & Raras vezes \\
\hline & Algumas vezes \\
\hline & Usualmente \\
\hline & Sempre \\
\hline
\end{tabular}

55 - Quando desconheço algo, não hesito em admiti-lo.

\begin{tabular}{|l|l|}
\hline & Nunca \\
\hline & Raras vezes \\
\hline & Algumas vezes \\
\hline & Usualmente \\
\hline & Sempre \\
\hline
\end{tabular}




\section{Seção 3 - Informações sobre a empresa}

Essa seção do questionário quer conhecer mais sobre a sua empresa atualmente.

1) Atualmente, a empresa que serviu de base para você responder este questionário:

$\square$ Continua existindo legalmente e está operante

$\square$ Continua existindo legalmente, mas não está mais operante

$\square$ Foi vendida

$\square$ Foi descontinuada

2) Você considera sua empresa inovadora (lançou novos produtos, criou novos processos)?

$\square$ Muito inovadora

$\square$ Inovadora

$\square$ Normal

$\square$ Pouco inovadora

$\square$ Nada inovadora

3) Qual o setor de atuação da empresa?

$\square$ Comércio tradicional

$\square$ Comércio eletrônico (e-commerce)

$\square$ Indústria

$\square$ Serviços

$\square$ Agricultura

$\square$ Outro. Qual? 


\section{Desempenho da empresa}

As questões a seguir são relacionadas ao desempenho de sua empresa nos últimos 3 anos. Assinale a alternativa que melhor representa o desempenho da sua empresa em cada um dos itens apresentados, levando em conta a variação deles nos últimos três anos (Leve em conta a variação nos últimos três anos e não a variação média anual).

1 - Quantidade de unidades vendidas. Lembre-se de considerar a variação dos últimos três anos

\begin{tabular}{|l|l|}
\hline & Diminuiu mais de $20 \%$ \\
\hline & Diminuiu entre $20 \%$ e $10 \%$ \\
\hline & Diminuiu menos de $10 \%$ \\
\hline & Permaneceu estável \\
\hline & Aumentou menos de $10 \%$ \\
\hline & Aumentou entre $10 \%$ e $20 \%$ \\
\hline & Aumentou mais de $20 \%$ \\
\hline
\end{tabular}

2 - Tamanho da carteira de clientes. Para responder a esta questão você deve considerar a variação na quantidade de clientes diferentes atendidos nos últimos três anos

\begin{tabular}{|l|l|}
\hline & Diminuiu mais de $20 \%$ \\
\hline & Diminuiu entre 20\% e 10\% \\
\hline & Diminuiu menos de $10 \%$ \\
\hline & Permaneceu estável \\
\hline & Aumentou menos de $10 \%$ \\
\hline & Aumentou entre 10\% e 20\% \\
\hline & Aumentou mais de $20 \%$ \\
\hline
\end{tabular}

3 - Faturamento

\begin{tabular}{|l|l|}
\hline & Diminuiu mais de $20 \%$ \\
\hline & Diminuiu entre $20 \%$ e $10 \%$ \\
\hline & Diminuiu menos de $10 \%$ \\
\hline & Permaneceu estável \\
\hline & Aumentou menos de $10 \%$ \\
\hline & Aumentou entre $10 \%$ e $20 \%$ \\
\hline & Aumentou mais de $20 \%$ \\
\hline
\end{tabular}


4 - Lucro líquido

\begin{tabular}{|l|l|}
\hline & Diminuiu mais de $20 \%$ \\
\hline & Diminuiu entre $20 \%$ e $10 \%$ \\
\hline & Diminuiu menos de $10 \%$ \\
\hline & Permaneceu estável \\
\hline & Aumentou menos de $10 \%$ \\
\hline & Aumentou entre $10 \%$ e $20 \%$ \\
\hline & Aumentou mais de $20 \%$ \\
\hline
\end{tabular}

5 - Quantidade de empregados

\begin{tabular}{|l|l|}
\hline & Diminuiu mais de $20 \%$ \\
\hline & Diminuiu entre $20 \%$ e $10 \%$ \\
\hline & Diminuiu menos de $10 \%$ \\
\hline & Permaneceu estável \\
\hline & Aumentou menos de $10 \%$ \\
\hline & Aumentou entre $10 \%$ e $20 \%$ \\
\hline & Aumentou mais de $20 \%$ \\
\hline
\end{tabular}




\section{Seção 4 - Informações pessoais}

A seguir são apresentadas mais algumas questões breves com o objetivo de enriquecer a pesquisa:

Fique tranquilo, essas são as últimas questões.

1) Você já foi o responsável pela criação de quantos novos negócios?

$\square 1$

$\square 2$

$\square 3$

$\square 4$ ou mais

2) Em relação à experiência de conduzir o processo de criação de uma empresa própria, assinale abaixo a alternativa que melhor expresse a sua vivência:

$\square$ Estou atualmente conduzindo o processo de criação de uma empresa própria

$\square$ Conduzi um processo de criação de empresa própria há mais de 2 anos

$\square$ Conduzi um processo de criação de empresa própria há mais de 5 anos

$\square$ Conduzi um processo de criação de empresa própria há mais de 10 anos

3) Você tinha conhecimento sobre o seu setor de atuação antes de iniciar a empresa?

$\square$ Conhecia muito sobre o setor

$\square$ Conhecia o setor, mas não o dominava por completo

$\square$ Conhecia um pouco do setor

$\square$ Não tinha nenhum conhecimento sobre este setor

4) Ano de nascimento

5) Sexo:

$\square$ Masculino

$\square$ Feminino 
6) Grau de escolaridade

$\square$ Pós-graduação - Lato Sensu, Mestrado, Doutorado

$\square$ Ensino superior completo

$\square$ Ensino superior incompleto

$\square$ Ensino médio completo

$\square$ Ensino médio incompleto

$\square$ Outro. Qual?

MUITO OBRIGADO!!! Seu formulário foi recebido.Com as suas respostas você contribuiu para aumentar o conhecimento sobre o comportamento dos empreendedores. Este conhecimento será muito útil para formar as futuras gerações de empreendedores. Agradeço imensamente sua dedicação de tempo e atenção. 


\subsection{APÊNDICE 2 - DETALHAMENTO DO PROCESSO EMPREENDEDOR}

\begin{tabular}{|c|c|c|c|}
\hline & $\begin{array}{c}\text { Processo } \\
\text { Empreende } \\
\text { dor }\end{array}$ & Sentenças Afirmativas & $\begin{array}{c}\text { Caus } \\
\text { ation/ } \\
\text { Effec } \\
\text { tuatio } \\
\text { n } \\
\end{array}$ \\
\hline & \multicolumn{3}{|c|}{ SUBPROCESSO 1: Ter a Ideia / Definir o conceito do negócio } \\
\hline & \begin{tabular}{|l|} 
Ação \\
empreende \\
dora \\
\end{tabular} & & \\
\hline 1 & $\begin{array}{l}\text { Ter a ideia } \\
\text { inicial }\end{array}$ & $\begin{array}{l}\text { Para a minha ideia inicial foram mais importantes o que eu sabia fazer e quem } \\
\text { eu conhecia do que o mercado }\end{array}$ & $\mathrm{E}$ \\
\hline 2 & $\begin{array}{l}\text { Definir o } \\
\text { conceito do } \\
\text { negócio } \\
\end{array}$ & Eu não tinha um conceito inicial de negócio & $\mathrm{E}$ \\
\hline 3 & $\begin{array}{l}\text { Evoluir o } \\
\text { conceito do } \\
\text { negócio }\end{array}$ & $\begin{array}{l}\text { O conceito do negócio foi construído pouco a pouco em função de adaptações } \\
\text { para atender a possíveis parceiros e clientes }\end{array}$ & $\mathrm{E}$ \\
\hline 4 & \begin{tabular}{|l|} 
Buscar \\
informações \\
de mercado \\
\end{tabular} & $\begin{array}{l}\text { Busquei informações, antes de iniciar a empresa sobre o mercado no qual eu } \\
\text { poderia atuar }\end{array}$ & $\mathrm{C}$ \\
\hline 5 & \begin{tabular}{|l|} 
Buscar \\
informações \\
de \\
concorrente \\
s \\
\end{tabular} & $\begin{array}{l}\text { Busquei informações antecipadas sobre quais seriam meus concorrentes e com } \\
\text { isso refinei meu conceito de negócio }\end{array}$ & $\mathrm{C}$ \\
\hline 6 & \begin{tabular}{|l} 
Definir os \\
segmentos \\
de clientes \\
que serão \\
atendidos
\end{tabular} & $\begin{array}{l}\text { Identifiquei nichos de mercado não explorados e, a partir deles, defini quem } \\
\text { seriam meus principais clientes e quais produtos/serviços eu deveria oferecer }\end{array}$ & $\mathrm{C}$ \\
\hline 7 & $\begin{array}{l}\text { Fazer o } \\
\text { Plano de } \\
\text { negócios }\end{array}$ & Fiz um plano de negócios completo antes mesmo de começar a minha empresa & $\mathrm{C}$ \\
\hline 8 & $\begin{array}{l}\text { Buscar } \\
\text { aprender } \\
\text { sobre o } \\
\text { negócio e } \\
\text { gestão } \\
\end{array}$ & $\begin{array}{l}\text { Fiz cursos e busquei conhecimentos que me dariam base para ser um } \\
\text { empreendedor melhor }\end{array}$ & $\mathrm{C}$ \\
\hline & \multicolumn{3}{|c|}{ SUBPROCESSO 2: Comprometer recursos } \\
\hline & \begin{tabular}{|l|} 
Ação \\
empreende \\
dora
\end{tabular} & & \\
\hline 9 & $\begin{array}{l}\text { Dedicar seu } \\
\text { tempo à } \\
\text { empresa }\end{array}$ & $\begin{array}{l}\text { Quando decidi abrir a minha empresa, deixei todas as minhas outras atividades } \\
\text { para me dedicar exclusivamente a isso }\end{array}$ & $\mathrm{C}$ \\
\hline $\begin{array}{l}1 \\
\mathbf{0}\end{array}$ & \begin{tabular}{|l|} 
Desenvolve \\
r o \\
produto/ser \\
viço
\end{tabular} & $\begin{array}{l}\text { Meu primeiro produto/serviço sofreu grandes influências das opiniões de futuros } \\
\text { clientes e fornecedores durante o seu desenvolvimento }\end{array}$ & $\mathrm{E}$ \\
\hline $\begin{array}{l}1 \\
1\end{array}$ & \begin{tabular}{|l|} 
Fazer \\
planejament \\
o financeiro
\end{tabular} & $\begin{array}{l}\text { Fiz uma previsão de todas as necessidades de investimento e projeções de } \\
\text { receita da futura empresa }\end{array}$ & $\mathrm{C}$ \\
\hline
\end{tabular}




\begin{tabular}{|c|c|c|c|}
\hline $\begin{array}{l}1 \\
2\end{array}$ & $\begin{array}{l}\text { Buscar } \\
\text { investiment } \\
\text { o }\end{array}$ & $\begin{array}{l}\text { Eu sabia que o valor máximo a ser investido na empresa deveria ser o dinheiro } \\
\text { que eu tinha disponível, mesmo que isso significasse não seguir o melhor para a } \\
\text { empresa }\end{array}$ & $\mathrm{E}$ \\
\hline $\mathbf{1}$ & $\begin{array}{l}\text { Investir } \\
\text { capital } \\
\text { próprio }\end{array}$ & $\begin{array}{l}\text { Economizei recursos por algum tempo até possuir o capital necessário para } \\
\text { iniciar a empresa }\end{array}$ & $\mathrm{C}$ \\
\hline $\begin{array}{l}1 \\
4\end{array}$ & \begin{tabular}{|l|} 
Buscar \\
recursos de \\
terceiros \\
(investidore \\
s, clientes e \\
fornecedore \\
s) \\
\end{tabular} & $\begin{array}{l}\text { Aceitei todos os recursos de terceiros que poderiam me ajudar a implementar a } \\
\text { empresa, mesmo que as condições oferecidas não fossem as melhores }\end{array}$ & $\mathrm{E}$ \\
\hline \begin{tabular}{l|l} 
\\
5
\end{tabular} & $\begin{array}{l}\text { Buscar } \\
\text { sócios }\end{array}$ & Só fiz sociedades com pessoas que tinham o perfil ideal que eu procurava & $\mathrm{C}$ \\
\hline & \multicolumn{3}{|c|}{ SUBPROCESSO 3: Criar a empresa } \\
\hline & \begin{tabular}{|l|} 
Ação \\
empreende \\
dora
\end{tabular} & & \\
\hline $\begin{array}{l}1 \\
6\end{array}$ & $\begin{array}{l}\text { Proteger a } \\
\text { propriedade } \\
\text { intelectual }\end{array}$ & $\begin{array}{l}\text { Encaminhei o processo de patenteamento e/ou direitos autorais dos meus } \\
\text { produtos/serviços }\end{array}$ & $\mathrm{C}$ \\
\hline 1 & \begin{tabular}{|l|} 
Adquirir \\
máquinas e \\
equipament \\
os
\end{tabular} & $\begin{array}{l}\text { Comecei a empresa com a estrutura mínima possível, sabendo que depois eu } \\
\text { poderia melhorá-la }\end{array}$ & $\mathrm{E}$ \\
\hline $\begin{array}{l}1 \\
8\end{array}$ & \begin{tabular}{|l|} 
Finalizar o \\
desenvolvi \\
mento do \\
produto/ser \\
viço
\end{tabular} & $\begin{array}{l}\text { Criei uma primeira versão comercializável do produto/serviço e já a coloquei no } \\
\text { mercado, mesmo sabendo que essa não era a versão ideal }\end{array}$ & $\mathrm{E}$ \\
\hline $\begin{array}{l}1 \\
9\end{array}$ & \begin{tabular}{|l|} 
Definir \\
local de \\
instalação \\
da empresa
\end{tabular} & $\begin{array}{l}\text { Busquei uma localização ideal para a minha empresa baseada nos benefícios e } \\
\text { vantagens que a escolha da localização pode oferecer }\end{array}$ & $\mathrm{C}$ \\
\hline $\begin{array}{l}2 \\
0\end{array}$ & $\begin{array}{l}\text { Definir } \\
\text { nome e } \\
\text { marca }\end{array}$ & $\begin{array}{l}\text { Pesquisei muito para definir o nome e a marca da empresa, inclusive me } \\
\text { preocupei em saber se eles já eram usados por outras empresas }\end{array}$ & $\mathrm{C}$ \\
\hline $\begin{array}{l}2 \\
1\end{array}$ & \begin{tabular}{|l|} 
Elaborar o \\
contrato \\
social para \\
registro da \\
empresa nos \\
órgãos \\
competentes \\
\end{tabular} & $\begin{array}{l}\text { Busquei conhecer e analisar a melhor forma jurídica para a empresa e suas } \\
\text { pretensões futuras. Conversei muito com o contador a respeito das } \\
\text { possibilidades }\end{array}$ & $\mathrm{C}$ \\
\hline & \multicolumn{3}{|c|}{ SUBPROCESSO 4: Gerenciar os primeiros anos de vida } \\
\hline & \begin{tabular}{|l|} 
Ação \\
empreende \\
dora
\end{tabular} & & \\
\hline $\begin{array}{l}2 \\
2\end{array}$ & $\begin{array}{l}\text { Realizar a } \\
\text { primeira } \\
\text { venda }\end{array}$ & $\begin{array}{l}\text { A primeira venda da empresa aconteceu para um cliente que se enquadrava } \\
\text { exatamente no público-alvo que eu planejara }\end{array}$ & $\mathrm{C}$ \\
\hline $\begin{array}{l}2 \\
3\end{array}$ & $\begin{array}{l}\text { Efetuar a } \\
\text { primeira } \\
\text { ação de }\end{array}$ & $\begin{array}{l}\text { As primeiras ações de divulgação da empresa foram feitas boca a boca por } \\
\text { pessoas do meu relacionamento }\end{array}$ & $\mathrm{E}$ \\
\hline
\end{tabular}




\begin{tabular}{|c|c|c|c|}
\hline & divulgação & & \\
\hline \begin{tabular}{l|}
2 \\
4
\end{tabular} & $\begin{array}{l}\text { Contratar } \\
\text { primeiros } \\
\text { colaborador } \\
\text { es }\end{array}$ & $\begin{array}{l}\text { Contratei meu primeiro empregado mais pela confiança que eu tinha na pessoa e } \\
\text { na possibilidade de pagar seu salário. Isso foi menos importante do que ter o } \\
\text { perfil ideal }\end{array}$ & $\mathrm{E}$ \\
\hline $\begin{array}{l}2 \\
5\end{array}$ & $\begin{array}{l}\text { Fazer } \\
\text { controles } \\
\text { financeiros }\end{array}$ & $\begin{array}{l}\text { Acompanhava rotineiramente as finanças da empresa para ter certeza de que } \\
\text { tudo seguia como eu havia planejado }\end{array}$ & $\mathrm{C}$ \\
\hline $\begin{array}{l}2 \\
6\end{array}$ & $\begin{array}{l}\text { Tomar } \\
\text { decisões } \\
\text { estratégicas }\end{array}$ & $\begin{array}{l}\text { Procuro assumir alguns riscos ao definir as ações/projetos/iniciativas da } \\
\text { empresa, pois assim posso aproveitar mais oportunidades }\end{array}$ & $\mathrm{E}$ \\
\hline
\end{tabular}




\subsection{APÊNDICE $3-$ TESTE DE PERFIL EMPREENDEDOR} (MCCLELLAND)

\section{Conheça suas características comportamentais empreendedoras}

Avaliação das características comportamentais empreendedoras, com base no estudo desenvolvido por David McClelland, estudioso de Harvard que se especializou em comportamento empreendedor.

1. Leia cuidadosamente cada afirmação e decida qual melhor se aplica a você (considere como você é hoje, e não como gostaria de ser). Seja honesto (a) consigo mesmo. Lembre-se de que ninguém faz tudo corretamente, nem mesmo é desejável que se saiba fazer tudo.

2. Selecione o número correspondente à afirmação que o descreve:

$1=$ nunca

$2=$ raras vezes

$3=$ algumas vezes

4 = usualmente

3. Algumas afirmações podem ser similares, mas nenhuma é exatamente igual.

4. Este questionário se constitui de diferentes etapas em sequência, leia atentamente todas as questões.

\begin{tabular}{|l|l|l|l|l|l|}
\hline \multicolumn{1}{|c|}{ Afirmações } & Nunca & $\begin{array}{l}\text { Raras } \\
\text { Vezes }\end{array}$ & $\begin{array}{c}\text { Algumas } \\
\text { Vezes }\end{array}$ & Usualmente & Sempre \\
\hline $\begin{array}{l}\text { 1. Esforço-me para realizar as coisas que } \\
\text { devem ser feitas. }\end{array}$ & & & & & \\
\hline $\begin{array}{l}\text { 2. Quando me deparo com um problema } \\
\text { difícil, levo muito tempo para encontrar a } \\
\text { solução. }\end{array}$ & & & & & \\
\hline 3. Termino meu trabalho a tempo. & & & & & \\
\hline $\begin{array}{l}\text { 4. Aborreço-me quando as coisas não são } \\
\text { feitas devidamente. }\end{array}$ & & & & \\
\hline $\begin{array}{l}\text { 5. Prefiro situações em que posso controlar } \\
\text { ao máximo o resultado final. }\end{array}$ & & & & & \\
\hline $\begin{array}{l}\text { 6. Gosto de pensar no futuro. } \\
\text { 7. Quando começo uma tarefa ou projeto } \\
\text { novo, coleto todas as informações possíveis } \\
\text { antes de dar prosseguimento a ele. }\end{array}$ & & & & & \\
\hline $\begin{array}{l}\text { 8. Planejo um projeto grande dividindo-o em } \\
\text { tarefas mais simples. }\end{array}$ & & & & & \\
\hline $\begin{array}{l}\text { 9. Consigo que os outros apoiem minhas } \\
\text { recomendações. }\end{array}$ & & & & & \\
\hline $\begin{array}{l}\text { 10. Tenho confiança que posso ser bem- } \\
\text { sucedido em qualquer atividade que me }\end{array}$ & & & & & \\
\hline
\end{tabular}


proponha executar.

11. Não importa com quem fale, sempre escuto atentamente.

12. Faço as coisas que devem ser feitas sem que os outros tenham que me pedir.

13. Insisto várias vezes para conseguir que as outras pessoas façam o que desejo.

14. Sou fiel às promessas que faço.

15. Meu rendimento no trabalho é melhor do que $o$ das outras pessoas com quem trabalho.

16. Envolvo-me com algo novo só depois de ter feito todo o possível para assegurar o seu êxito.

17. Acho uma perda de tempo me preocupar com o que farei da minha vida.

18. Procuro conselhos das pessoas que são especialistas no ramo em que estou atuando.

19. Considero cuidadosamente as vantagens e desvantagens de diferentes alternativas antes de realizar uma tarefa.

20. Não perco muito tempo pensando em como posso influenciar as outras pessoas.

21. Mudo a maneira de pensar se outros discordam energicamente dos meus pontos de vista.

22. Aborreço-me quando não consigo o que quero.

23. Gosto de desafios e novas oportunidades.

24. Quando algo se interpõe entre o que eu estou tentando fazer, persisto em minha tarefa.

25. Se necessário, não me importo de fazer o trabalho dos outros para cumprir um prazo de entrega.

26. Aborreço-me quando perco tempo.

27. Considero minhas possibilidades de êxito ou fracasso antes de começar atuar.

28. Quanto mais específicas forem minhas expectativas em relação ao que quero obter na vida, maiores serão minhas possibilidades de êxito.

29. Tomo decisões sem perder tempo buscando informações.

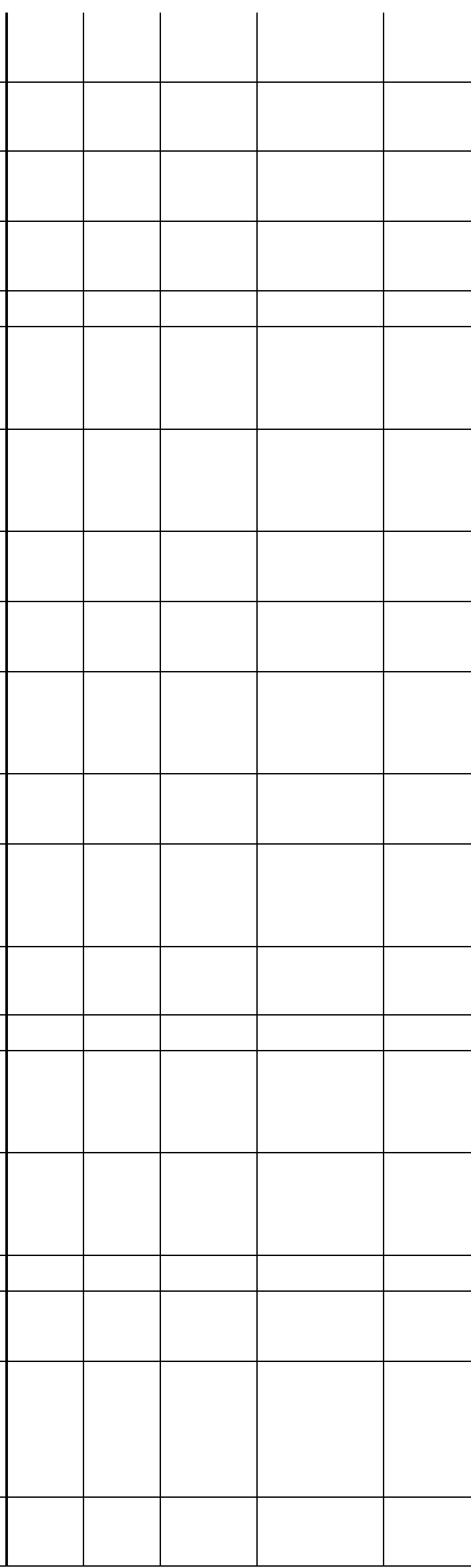


30. Trato de levar em conta todos os problemas que podem se apresentar e antecipo o que faria caso sucedam.

31. Conto com pessoas influentes para alcançar minhas metas.

32. Quando estou executando algo difícil e desafiador, tenho confiança em meu sucesso.

33. Tive fracassos no passado.

34. Prefiro executar tarefas que domino perfeitamente e com as quais me sinto seguro.

35. Quando me deparo com sérias dificuldades, rapidamente passo para outras atividades.

36. Quando estou fazendo um trabalho para outra pessoa, me esforço de forma especial para que fique satisfeita com o trabalho.

37. Nunca fico totalmente satisfeito com a forma como são feitas as coisas; sempre considero que há uma maneira melhor de fazê-las.

38. Executo tarefas arriscadas.

39. Conto com um plano claro de vida.

40. Quando executo um projeto para alguém, faço muitas perguntas para assegurar-me de que entendi o que quer.

41. Enfrento os problemas na medida em que surgem, em vez de perder tempo antecipando-os.

42. Para alcançar minhas metas, procuro soluções que beneficiem todas as pessoas envolvidas em um problema.

43. O trabalho que realizo é excelente.

44. Em algumas ocasiões obtive vantagens de outras pessoas.

45. Aventuro-me a fazer coisas novas e diferentes das que fiz no passado.

46. Tenho diferentes maneiras de superar obstáculos que se apresentam para a obtenção de minhas metas.

47. Minha família e vida pessoal são mais importantes para mim do que as datas que determinei para entrega de trabalhos.

48. Encontro a maneira mais rápida de terminar os trabalhos, tanto em casa quanto no trabalho.

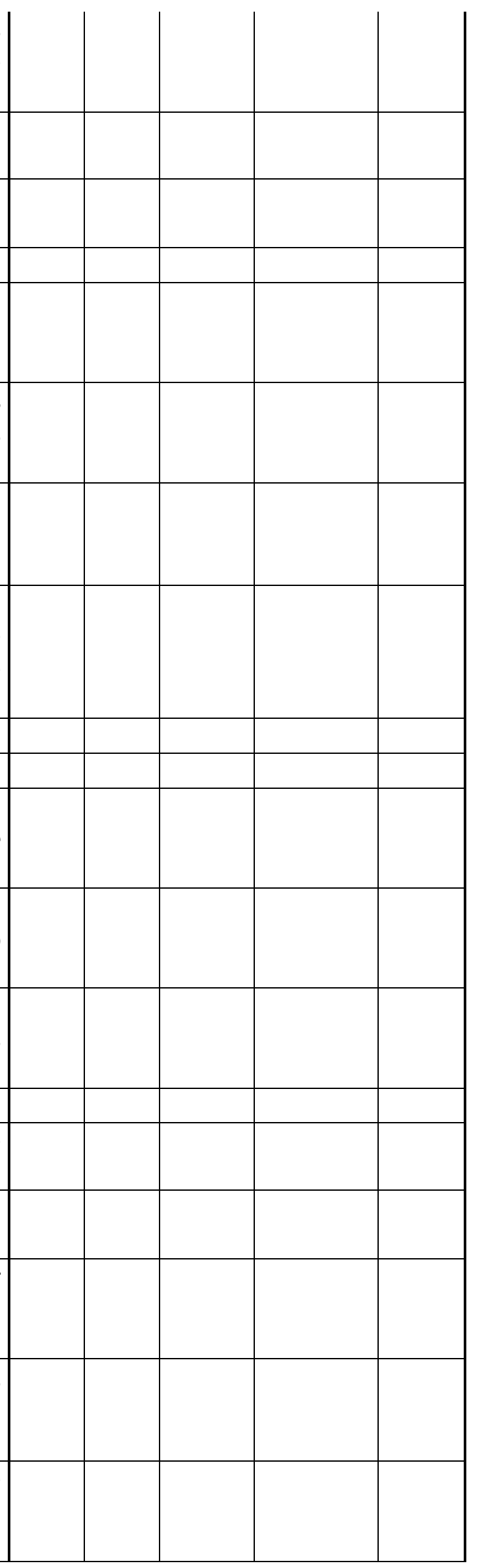




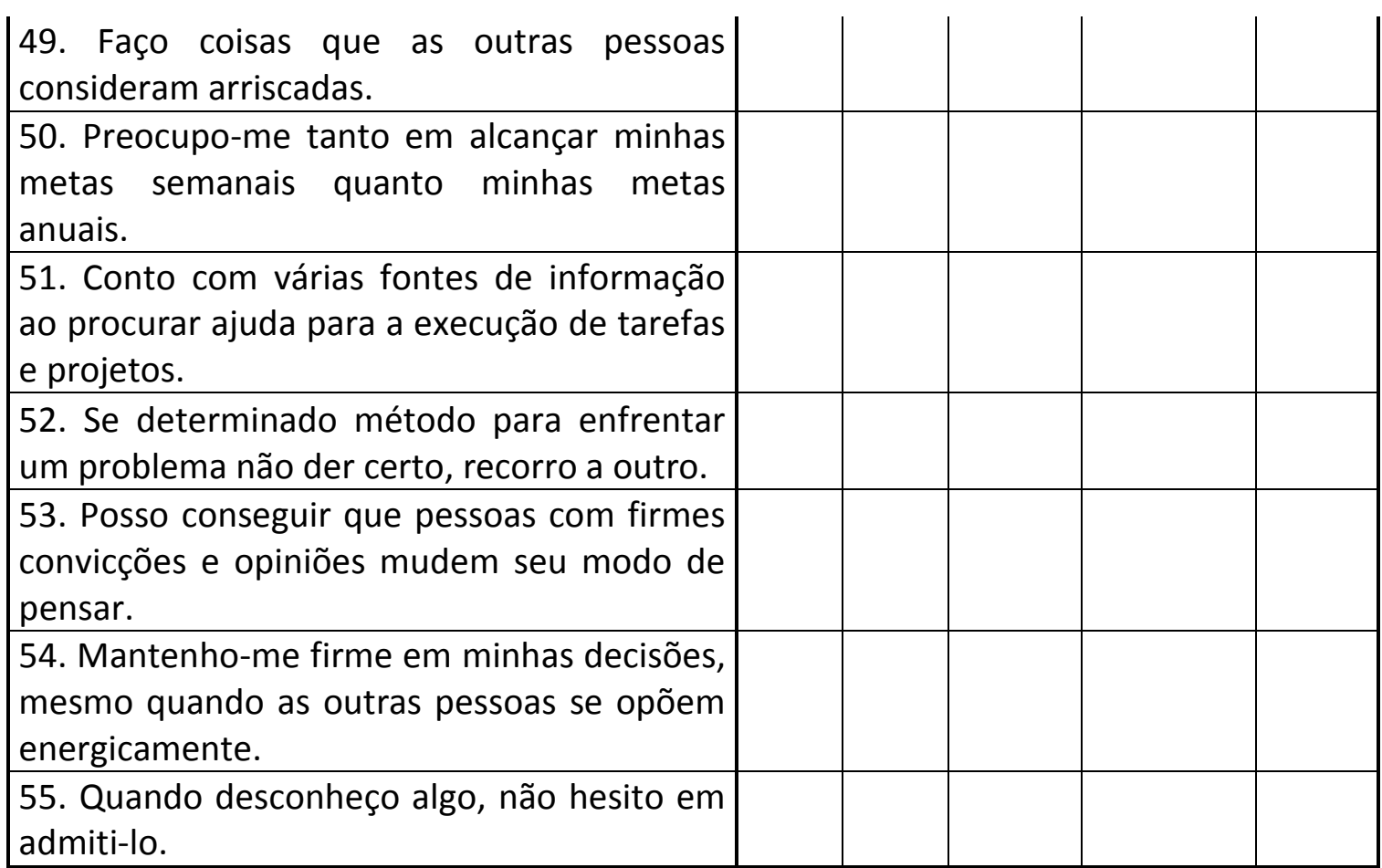

